\author{
NABA KUMAR ADAK \\ Sabang Sajanikanta Mahavidyalaya, West Bengal, India
}

\title{
MODERN MONEY THEORY, BY DEFINING MONEY AS STATE-ISSUED DEBT INSTRUMENT, FAILED TO PROVIDE SUFFICIENT SPENDING FOR SECURING FULL EMPLOYMENT; BUT SUCCEEDED IN BLURRING OUR UNDERSTANDING OF MONEY
}

\begin{abstract}
:
The purpose of this paper is to explain MMT's misconception and misrepresentation relating to money's origin, character and function, and monetary $\&$ fiscal policies. The MMT is a conglomeration of different contradictory and already discarded theories put forward by earlier economists like Credit Theory of A. Mitchell Innes, State Theory or Chartalist Theory of money of Georg Friedrich Knapp, combination of Credit Theory and State Theory of money by Geoffrey Ingham (in his article "Money is a Social Relation"), Functional Finance theory of Abba Lerner, Money theory of Keynes, Sectoral Balance Approach of Wynne Godley and so on. The MMT developed another unique theory called Consolidation between the Government and the Central Bank. Though MMT claims that it provides an alternative definition of money, yet, in reality, it does not want to explore what money is and how money had been evolved as a medium of exchange. The MMT argues that in the modern capitalist system, money is nothing but a numeraire or an account of credit (debt) and has no intrinsic value of its own and that money is neither pegged to any commodity nor a medium of exchange. The MMT, then, begins to impose this theory (money is a state-issued debt instrument) on the history of evolution of money. Therefore, their explanation does not reflect how money really evolved or what money really is.

Other purpose of this paper is to explain that these concepts and theories of MMT are hypothetical and have no connection with how present economy is functioning. If the suggestion, of MMT for increasing budget-deficit without provisioning how the debt (for financing the deficit) will be redeemed, is followed blindly then the economy as a whole will be led to a catastrophe and collapse. This conceptual/ theoretical paper concludes that the MMT became a hotchpotch combination of impractical fanciful and arbitrarily concocted theories. Therefore, the MMT became the most un-intelligible theory. It is not at all functional. So, this exercise (criticism of MMT) is necessary in order to eliminate the negative impacts of the MMT on the theories and practices of economics at large.

Another purpose of this paper is to show that the primary cause of most of the economic anomalies is money's entrance into the economy from its issuer the central bank as debt. This paper suggests that economists should formulate such a theory that will free money from its debt nature. This paper concludes that the very nature of money's origin as debt (from the central bank to the economy) is a systemic defect and this defect is primarily responsible for continuous economic downturn and frequent recession. However, the MMT does not try to find how this debt-nature of money can be eliminated. On the contrary, the MMT gives emphasis that money (even commodity money) should be recognized as nothing but a debt-instrument.

Therefore, this paper implores that some theory should be constructed so that money can originate as "debt-free". If money originates free of debt only then sustainable economic growth can be secured.
\end{abstract}




\section{Keywords:}

Functional finance, hierarchy of money, Modern Money Theory, credit theory of money, state theory of money, printing money, theory of consolidation between the government and the central bank, full employment, High Powered Money, barter through caste system, sectoral balance approach

JEL Classification: B59, E52, E62 


\section{Introduction:}

"MMT is a relatively new approach that builds on the insights of John Maynard Keynes, Karl Marx, A. Mitchell Innes, George F. Knapp, Abba Lerner, Hyman Minsky, Wynne Godley, and many others stretching back to Adam Smith and before" [like Geoffrey Ingham, J. A. Schumpeter, David Greaber, C. A. F. Goodhart, Philip Grierson, etc.]. [Wray June 2014, p.2]

"In recent years an approach to macroeconomics called Modern Money Theory (MMT) has been developed. In my view, it is a synthesis of several strands of heterodox-largely Post Keynesianthought. It draws heavily on the work of Georg Friedrich Knapp, A. Mitchell Innes, John Maynard Keynes, Abba Lerner, Hyman Minsky, and Wynne Godley, to integrate the state theory of money, endogenous money, functional finance, financial instability hypothesis, and sectoral balance approaches. I would characterize it the way that Minsky (1977) characterized his own attempt at a synthesis: it "stands on the shoulders of giants."' [Wray Jan. 2018, p. 2] L. Randall Wray is the leading MMT Economist and Senior Research Associate for Full Employment and Price Stability, University of Missouri-Kansas City, and Senior Scholar of Jerome Levy Economics Institute. He asserts that, "we began creating what came to be called MMT". [Wray Jan. 2018, p. 2]. Since 1980s, other prominent economists those are working on MMT are Warren Mosler, Bill Mitchell, Jan Kregel, Stephanie Kelton Bell, Pavlina Tcherneva, Mathew Forstater, Ed Nell, Scott Fullwiler, Eric Tymoigne, Joelle LeClaire, Heather Starzinsky, Daniel Conceicao, Felipe Rezende, Flavia Dantas, Yan Liang, Fadhel Kaboub, Zdravka Todorova, Andy Felkerson, Nicola Matthews, Shakuntala Das, Corinne Pastoret, Mike Murray, Alla Semenova, Yeva Nersisyan, Dimitri Papadimitriou, Maurice Sammuels, Cliff Viner, Scott Ramsey, and many others.

"The first academic monograph introducing the approach was Understanding Modern Money: The key to full employment and price stability, by L. Randall Wray (1998). The three main research institutions that developed MMT are The Center for Full Employment and Price Stability (University of Missouri-Kansas City), The Centre of Full Employment and Equity (University of Newcastle, Australia), and the Levy Economics Institute (Bard College).” [Wray 2019 Sept., p. 2]

"Its [MMT's] research has stretched across the sub-disciplines of economics, including history of thought, economic history, monetary theory, unemployment and poverty, finance and financial institutions, sectoral balances, cycles and crises, and monetary and fiscal policy. It has largely updated and synthesized various strands of theory, most of it heterodox — outside the mainstream." [Wray June 2014, p-2] "MMT reaches conclusions that are shocking to many who've been indoctrinated in the conventional wisdom. Most importantly, it challenges the orthodox views about government finance, monetary policy, the so-called Phillips Curve (inflation-unemployment) trade-off, the wisdom of fixed exchange rates, and the folly of striving for current account surpluses." [Wray June 2014, p-3]

However, MMT has neither ushered any new policy formulation, nor has it modified the existing monetary and fiscal system. It fails to define money. According to the MMT never there was money; buying and selling are being done by only exchanging each other's monetary instruments called IOUs.

MMT is a conglomeration of different contradictory and impractical theories put forward by earlier economists. They are: Credit theory of Innes, State theory or chartalist theory of money of Georg Friedrich Knapp, (Ingham combined credit theory and state theory of money in his article "Money is a Social Relation), functional finance theory of Lerner, Money theory of Keynes. The MMT develops a 
new theory called consolidation between the government and the central bank theory. Thus, MMT (as it is based on wrong theories) became a hotchpotch contributing, to the understanding of the nature of money, monetary policy and fiscal policy, a theory that is un-intelligible and very much unrealistic and not at all functional.

The MMT does not really want to explore what money is or/ and how money had been evolved as a medium of exchange. The MMT argues that in the modern capitalist system, money is nothing but a numeraire or an account of credit (debt) and has no intrinsic value of its own and that money is neither pegged to commodity nor a medium of exchange. The MMT, then, begins to impose this theory on the history of evolution of money. Therefore, their explanation does not reflect how money really evolved

In the Credit theory of Money, money by nature, is a monetary (debt) instrument and not a medium of exchange and derives its value not from its intrinsic value but from the declaration of its issuing authority (government). Money is nothing but a numeraire (just the number of units of government's debt written on it). In the state theory of money, money is (as Keynes put it) what the states issues, denominates and spends and forces the taxpayers to pay as taxes to the state. The MMT integrates these two theories (credit theory of money and state theory of money) thus: the money that the state issues is state's debt from out of nothing and the state transfers the obligation to redeem the state's debt to the tax-payers and when the tax-payers pay the tax, both the government and the tax-payers become debt-free (their debts are redeemed). Lerner's Functional finance theory comprises of two basic ideas. One idea is that the state can spend as much money as it needs to accomplish its duties and can meet obligations without depending on receipts from tax and bond-sales. The second idea is that the state will tax people to redeem the government's debt so that the people are forced to accept its money so that they can tax with it (tax drives money). The state will sale bonds to help people to save their money in the bonds and, thus, to help the central bank to maintain the interest rate target. According to Consolidation theory (developed by the MMT), the government (the Treasury) and the central bank co-operate with one another in executing monetary and fiscal policies. The MMT also thinks that there is a hierarchy of money from state money to private money in descending order. The MMT concludes that the state can crate and spend as much money as it needs to achieves full employment and price stability.

In the literary survey, at first, I will assess the MMT's major theoretical constructions like Credit theory of money, State theory of money, Hierarchy of money, theories relating to Tax and Bond, theory of Functional Finance, theory of Consolidation between the central bank and the government, and the theory that the Government is the Employer of Last Resort and so on.

Then, I will make an assessment of all of these theories together. Thereafter, I will try to explain limitations in the MMT's understanding relating to their various concepts. Then, I will explain what really ails the economy. Here, I will explain that the very nature of money's origin as debt is a systemic defect that is primarily responsible for the continuous economic downturn. Then, I will conclude, put suggestion, and confess my limitations. At the end, I will explain why and how my findings are new additions to the existing knowledge on money, monetary policy, and fiscal policy.

\section{Literature Survey:}

Here, I will briefly narrate what the MMT is about. I found that the theories of MMT are founded on grossly wrong theories formulated by earlier economists. Those theories are: the Credit (debt) Theory of 
Money, the State Theory of Money, theory of Hierarchy of Money, theory relating to Taxes and Bonds, theory of Functional Finance, theory of Consolidation between the Central Bank and the Government, theory of Government is the Employer of Last Resort

\subsection{The Credit (Debt) Theory of Money:}

The MMT is heavily indebted, for this theory, to the book "The Credit Theory of Money" of A. Mitchell Innes. Innes explained his 'credit theory' thus: "Shortly. The Credit Theory is this: that a sale and purchase is the exchange of a commodity for credit. From this main theory springs the sub-theory" that "the right of the debtor [is] to release himself from his debt by the tender of an equivalent debt owed by the creditor, and the obligation of the creditor to accept this tender in satisfaction of his credit." [Innes 1914, p.152]

However, this theory is full of flaws and unintelligible contradictions. The very basic foundation of Innes' credit theory "that a sale and purchase is the exchange of a commodity for credit" is erroneous and does not corroborate to the facts. A sale or purchase can only be complete if the values of the things (commodities or services) that are being exchanged become equal. After the purchase or sale, neither party (seller or purchaser) (both are seller or purchaser in their turn) remains creditor or debtor to one another. A sale or purchase will be the exchange of a commodity for credit if, and only if, the purchaser cannot offer anything of the same intrinsic value against the thing (having an intrinsic value) that he buys and gives his IOU of the same value to the seller. Therefore, 'the exchange of commodity for credit' takes place in a borrowing and lending, not in 'a sale and purchase'. Therefore the basic concept (Innes considers it as his "main theory") "“that a sale and purchase is the exchange of a commodity for credit" is a wrong proposition on which Innes' 'the credit theory of money' is based/ founded.

Innes continues, "From this main theory springs the sub-theory that the value of credit or money does not depend on the value of any metal or metals, but on the right which the creditor acquires to "payment," that is to say, to satisfaction for the credit, and on the obligation of the debtor to "pay" his debt and conversely on the right of the debtor to release himself from his debt by the tender of an equivalent debt owed by the creditor, and the obligation of the creditor to accept this tender in satisfaction of his credit." Innes describes how this system functions thus: "A is debtor to $\mathrm{B}$ and gives his obligation or acknowledgement of debt. Shortly afterwards, B becomes debtor to A and hands back the acknowledgement. The debt of A to B and of B to A, the credit of B on A and that of A on B are thereby cancelled." [Innes 1914, p. 161].

However, this is the most impracticable theory. Here, Innes argues that the buyer (debtor) can or must redeem his debt by not offering anything of intrinsic value as repayment (redemption) of his debt to the seller (creditor), but "by the tender of an equivalent debt owed by the creditor". However, it is possible to get "an equivalent debt owed by the creditor" only if the creditor (seller) buys something of equivalent value from the buyer at a later time. In that case, once someone buys something from someone, the process must be reversed, that is the seller must buy something of 'equivalent value' from the buyer at a later date. This process can only be completed if the buyer possess something of 'equivalent value' what the seller wants to buy later. However, if every time "a sale and purchase" is to be reversed, then selling and purchasing will be very cumbersome and almost impossible. The process of lending first and being repaid back later cannot help trading in marketplace where people buy and sell things and people have no option to reverse their dealings with either the buyers or the sellers later. 
Innes knew this problem very well. However, Innes' intension was not to stick to his own theory. He wants to establish another theory that though the "fundamental theory" is that "the debtor to release himself from his debt by the tender of an equivalent debt owed by the creditor", but "in practice it is not necessary for a debtor to acquire credits on the same persons to whom he is debtor". [Innes 1914, p. 152] What Innes wanted is to suggest is not that the buyer (debtor) should 'acquire credits on the same persons to whom he is debtor', but acquire credit on the other persons to redeem his debt to his creditor (seller). But, again, Innes knew full well that it is almost impossible to obtain an "equivalent debt" from a third party buyer (debtor) and that the seller may not accept a debt of a third party from his debtor. It was not the intension of Innes also to assert. His hidden agenda was to establish that a debtor must acquire a debt only of a bank (and from none other than a bank) and must pay his debt to the seller with the bank's debt.

Thus, Innes shifted from or twisted twice his 'fundamental theory' that "a sale and purchase is the exchange of a commodity for a credit". First, he altered his 'fundamental theory' by asserting that the buyer (debtor) must acquire a debt of a third party, and then (for second time), he altered this argument by suggesting that the third party must be none other than a bank (just debt of any third party will not do). Therefore, Innes writes, "Such is the fundamental theory, but in practice it is not necessary for a debtor to acquire credits on the same persons to whom he is debtor. We are all both buyers and sellers, so that we are all at the same time both debtors and creditors of each other, and by the wonderfully efficient machinery of the banks to which we sell our credits, and which thus become the clearing houses of commerce, the debts and credits of the whole community are centralized and set off against each other. In practice, therefore, any good credit will pay any debt." [Innes 1914. p. 152] Here Innes argues that when we buy goods and services we pay with the debt of the bank (according to Innes a third party), the debt that banks owe to us, when we deposit our credits in the bank. However, though Innes writes, "We are all both buyers and sellers, so that we are all at the same time both debtors and creditors of each other", yet he does not really mean to hold both parties in "a sale and purchase is the exchange" as creditor or/and seller in their turn; Innes' purpose was to establish that only the buyer (who pays money in exchange of something) is a debtor (not creditor) and only the seller of a thing (not money) is a creditor (not debtor). Therefore, here, also Innes twisted his argument that both the seller and the buyer are either debtor or creditor by reasserting that only buyers will be treated as debtors and only the sellers will be treated as creditors.

Innes revised his earlier argument that debt instrument of any third party will do by the new argument that this third party must be a bank only whose debt-instrument a debtor (buyer) must acquire to repay his debt to the creditor (seller). Innes refers to a "wonderfully efficient machinery of the banks to which we sell our credits" and we buy something with the debt (that the banks owe against our credit in the banks) of the bank. Innes writes, "Again in theory we create a debt every time we buy and acquire a credit every time we sell, but in practice this theory is also modified, at least in advanced commercial communities. When we are successful in business, we accumulate credits on a banker and we can then buy without creating new debts, by merely transferring to our sellers a part of our accumulated credits. Or again, if we have no accumulated credits at the moment we wish to make a purchase, we can, instead of becoming the debtors of the person from whom we buy, arrange with our banker to "borrow" a credit on his books, and can transfer this borrowed credit to our seller, on undertaking to hand over to the banker the same amount of credit (and something over) which we acquire when we, in our turn, become sellers." [Innes 1914, p. 152]. 
However, it is not also the purpose to establish that the bank's debt (issued against our credit in the bank) is the only third party's debt that we pay when we buy. Innes' intention is to establish the debt of the government (and not of the banks) as the only debt instrument that must be considered as third party's debt that we can pay when we buy. Therefore, after mentioning "the wonderfully efficient mechanism of the banks" as the only provider of debt, Innes hastened to refer to government as the only source/ provider of 'third party's debt'. Innes writes, "Then again, the government, the greatest buyer of commodities and services in the land, issues in payment of its purchases - vast quantities of small tokens which are called coins or notes, $\ldots$ and these credits on the government we can use in the payment of small purchases in preference to giving credits on ourselves or transferring those on our bankers. So numerous have these government tokens become in the last few centuries and so universal their use everyday life - far exceeding that of any other species of money - that we have come to associate them more especially with the word "money."”. [Innes 1914, p. 152]

Thus, Innes, initially started by saying that, after a sale or purchase, a buyer (debtor) must repay his debt to the seller (creditor) with the seller's debt. Then Innes added that the debtor may find any third party's debt (instead of a debt of the seller) to pay for redeeming his debt to his creditor (seller). Again, Innes shifted his position. He asserts that the debt of any third party will not do; only the debt of a bank must be treated as the third party's debt. Again, Innes shifted his position by saying that only the government's debt (that the government incurs in purchasing our goods and services) must be treated as the third party's debt.

If we must acquire a debt (third party's debt) instrument from a bank or a government in exchange of/ against a deposit of our credits (commodities) to be able to pay for what we buy, then why we cannot pay those commodities (commodity-money) directly to the seller when we buy something. Innes answers that before we can use a commodity as money the commodity has to be stamped or minted by some authorized minter. Banks and the governments are the accepted minters who stamp or mint the commodity into commodity-money. Innes argue that when a person deposits a lump of commodity (gold or silver) in the mint of a bank or government and the mint hands over the depositor a stamped commodity-money, it is not just handing back to the owner (depositor) of the commodity in the form of money; but an act of buying and selling. Innes argues according to the law of "a sale and purchase is the exchange of a commodity for a credit", the mint just becomes a debtor when it buys (receives) the lump of a commodity (gold or silver) and repays its debt to its creditor (the seller/ owner of the commodity) with a stamped-money (commodity money) that, according to Innes, is the debt-instrument of the bank. Thus, according to Innes, every stamped and minted money is a debt-instrument of the minter (bank or government). Innes writes, "The Government of the United States does not profess to buy gold. All it professes to do is to accept it on deposit, make it into bits called standard dollars, stamp them with a guarantee of weight and purity, and hand them back to the owner, or, if he wishes it, he will be given a certificate or certificates in place of the gold. Now I again wish to emphasize the fact that it is not what the government professes to do that matters, but what it actually does. The fact that the law regards this transaction as a deposit does not make it so. The transaction is not really a deposit, but a sale and purchase. In exchange for each ounce of gold the owner receives in money. If the gold were merely taken on deposit, or for the purpose of stamping it without, giving, to the owner of the stamped metal, any special right to pay his taxes with his gold, that is to say without investing the gold with the character of an obligation, without making it into money, the transaction would be a deposit, but not otherwise." [Italics are mine] [Innes 1914, p. 162]. 
Here, Innes argues that stamping on the coin is a kind of "investing the gold with the character of an obligation" for the holder of money (coin) "to pay his taxes with his gold". It means that by only stamping on the coin, the government obliges the holder of the coin (who comes to mint his bullion into coin) to pay tax to the government to redeem government's debt. However, these coins are not those coins that the government spends to purchase commodities and services. The coins that the government spends are minted by the government mint out of the gold and silver that the government has already reserved in its treasury. If the coins that are minted and handed over to the people who come to mint their gold and silver into coins are regarded as debt of the government and if the government obliges the holder of that coins to repay its (government's) debt by way of tax payments, then, how can those coins, that are minted out of the government's bullion reserve, also become debt of the government that also must be redeemed by the same way of payment of taxes by the receiver (the seller who sells his services or commodities to the government)? Both types of coins minted by the government mint (one that is minted for the people who brings gold for minting and another that is minted out of government's own bullion cannot be treated as debt of the government. The fact is that none of these two types of money is government's debt as Innes wants us to accept or believe.

However, it is unintelligible if "In exchange for each ounce of gold the owner receives in money', how that act of exchange acquire the quality of "investing the gold with the character of an obligation" of the government. What Innes willfully avoids in stating is that the minter (bank or government) does not just exchange money with an ounce of gold, but receives a wage/ minting charge. If I hire a carpenter to make a table and pay him his wage, will it be considered that I receive the table as a debt-instrument of the carpenter and that the table is not my own? Besides, if I pay gold in purchasing steel, why the payment of gold will be treated as a debt-instrument, while both the commodities that are exchanged are of equal value? If I exchange banana with fish, which of these two commodities will be considered as debtinstrument? We will not be able to answer these questions correctly if we adhere to the credit theory of Innes. Against all these odds, Innes still argues that government money "have no more claim to the title than any other tokens or acknowledgement of debt" [Innes 1914, p. 152] and asserts that "The government-stamp on a piece of gold changes the character of the gold from that of a mere commodity to that of a token of indebtedness." [Innes 1914, p. 168]. Therefore, Innes is wrong in trying to establish his "fundamental theory" of "a sale and purchase is the exchange of a commodity for credit."

Innes argues that a debtor (buyer) must redeem his obligation of debt by offering an equivalent debt of the creditor (seller). Innes gives an example how a debt of a buyer (debtor) can be redeemed by paying the debt of the creditor (seller) to the creditor. He writes, "government's debt (the money that the government pays for purchasing) to the seller (creditor, here the seller from whom the government buys) can be redeemed if the seller gives back that money (government's debt) to the government as tax. But it is a wrong argument and contrary to Innes theory that debtor must redeem his debt by paying creditor's debt to creditor. But in this case, creditors (the sellers) are paying debtor's debt to the debtor (the government) as tax to redeem the debtor's (government's) debt. It seems that Innes wants to prove that the money is government's debt, by hook or by crook, even if his "fundamental theory" has to be contradicted. In arguing this way, Innes misleads us that tax is a debt. Tax is not a debt; it is a payment against government services that the people receive in exchange of tax.

Innes also misleads us by stating that even commodity-money and certificates of commodity are debt. Innes argues that the quantity of metal in commodity-moneys differs from place to place and from 
time to time. People usually reduce the shape and size of a coin through continuous clipping; thus dollars can vary in their weight, value, size and acceptability. Innes writes, "As can be clearly proved by careful study of history, a dollar or a pound or any other monetary unit is not a fixed thing of known size and weight, and of ascertained value, nor did government money always hold the pre-eminent position which it to-day enjoys in most countries - not by any means." [Innes 1914, p.152] Innes cites examples: "the German States, where there were literally hundreds of monetary standards, all called the same name of Mark -- the history of money is particularly involved, and the fact that the retail trade always followed a lower standard than did the wholesale trade in the same place." [Innes 1914, p. 154]. "It is hard to get the public to realize this functional principle, without a true understanding of which it is impossible to grasp any of the phenomena of money. Hard, too, is it to realize that in America to-day, there are in any given place many different dollars in use" [Innes 1914, p. 154]. "Everybody who incurs a debt issues his own dollar, which may or may not be identical with the dollar of anyone else's money. It is a little difficult to realize this curious fact" [Innes 1914, p. 154] Therefore, Innes argues that "The value of credit does not depend on the existence; of gold behind it, but on the solvency of the debtor." [Innes 1914, p. 168].

However, Innes is wrong. Commodity-money is not a debt and the issuer of the commodity-money is not bound to convert the commodity-money. Commodity-money can only be converted into any commodity through purchase or sale. The issuer may convert any certificate of money or token money (like paper money, e-money etc.) not because he is a debtor but because he the safe-keeper of the commodity against which he issued the token money. Therefore, the question of 'solvency' of the issuer of commoditymoney or of the money-certificate cannot arise, because he has already in his custody the commodity which he is using to create commodity-money or against which he is creating the money-certificates. Therefore, issuer of commodity-money or certificate-money is not at all a debtor.

According to Innes, if dollars cannot be identified by their uniform weight, value, size and acceptability (because they differ in different areas and times) then the dollars do not derive its acceptability and/ or value from its metal content. So, Innes prefers to think that dollar as a nomenclature of a debt that the issuer of dollar is obliged to redeem. Innes argues that, "What is stamped on the face of a coin or printed on the face of a note matters not at all; what does matter, and this is the only thing that matters is: What is the obligation which the issuer of that coin or note really undertakes, and is he able to fulfill that promise, whatever it may be?" [Innes 1914, p. 155] Innes writes, even "A government dollar is a promise to "pay," a promise to "satisfy," a promise to "redeem," just as all other money is. All forms of money are identical in their nature." [Innes 1914, p. 154] Therefore, Innes concludes that, "Credit and debt are abstract ideas, and we could not, if we would, measure them by the standard of any tangible thing. We divide, as it were, infinite credit and debt into arbitrary parts called a dollar or a pound, and long habit makes us think of these measures as something fixed and accurate; whereas, as a matter of fact, they are peculiarly liable to fluctuation.” [Innes 1914, p. 155] If we accept Innes' explanation of credit money theory, then we must accept that as mangoes do not have uniform size, weight and value, so mangoes are mangoes at all but only "credit and debt" and are "abstract ideas" and not "any tangible thing".

However, Innes is wrong in understanding that coins and certificates do not derive their value from the commodity that they represent but are only debts (obligation of a debtor). Where from the debt derives its face value? Innes answers that, "The value of credit (according to Innes, issuer's debt in the form of money) does not depend on the existence; of gold behind it, but on the solvency of the debtor (issuer of money)" [Innes 1914, p. 168]. He further explains, "The holder of a coin or certificate has the absolute 
right to pay any debt due to the government by tendering that coin or certificate, and it is this right and nothing else which gives them their value." [Innes 1914, p. 161]. Innes adds, "a government issue of money must be met by a corresponding tax. It is the tax which imparts to the obligation its "value." A dollar of money is a dollar, not because of the material of which is made, but because of the dollar of tax which is imposed to redeem it." [Innes 1914, p. 165]. However, these answers of Innes does not satisfactorily meet the question where from the money (debt) derives its face value. Just returning or redeeming the debt to its issuer does not answer what the face value of the debt in units should be. Money must have some face value; otherwise it will not be ascertained how much money will redeem how much tax liability. Commodity-money gets its face-value from its metal-content and representative money (paper money) gets its value from the reserve (that the issuer keeps) against which the issuer issued it. Therefore, money derives its value not because "Government money is redeemed by taxation" [Innes 1914, p. 168] and "It is the tax which imparts to the obligation its "value"" [Innes 1914, p. 165] as Innes wants us to believe. Innes explained that "coin or certificate ... acquired their value by taxation." [Innes 1914, P. 160].

However, moneys that are not issued by the government but by other issuers do not need to be redeemed through payment as tax to their issuers. Innes writes that "The issue of money is not an exclusive privilege of government, but merely one of its functions, as a great buyer of services and commodities. Money in one form or another is, in fact, issued by banks, merchants, etc." [Innes 1914, p. 168] If government's money (debt) must be redeemed by taxation, and if "It is the tax which imparts to the obligation its "value"" [Innes 1914, p. 165], then by the same logic, bank's debts (money) must also be redeemed by paying tax to the bank. However, Innes does not argue in that way; on the contrary he writes, "A banker is one who centralizes the debts of mankind and cancels them against one another. Banks are the clearing houses of commerce." [Innes 1914, p. 168] If moneys, created by issuers other than the government, do not need to be redeemed then it is proved that money is not at all a debt (of its issuer).

Innes argues that when a person deposits an ounce of gold in a bank and gets a coin against it; the money must be considered as debt of the bank. We know that when a person deposits (lends) any money in a bank and the bank issues an IOU (savings accounts pass book) then the deposit is a debt of the bank Now, the question is whether both of these (money that is deposited and the IOU that issued against the deposit) should be treated as debt of the bank. If we accept Innes' theory that money is debt of the bank then we must treat the IOU as money of the bank but that is clearly not so.

Innes writes, "It is true that all the government paper money is convertible into gold coin; but redemption, of paper issues in gold coin is not redemption, at all, but merely the exchange of one form of obligation, for another of an identical nature." [Innes 1914, p. 165] However, Innes is wrong. The paper money is issued against the gold coin. Therefore, the value of gold coin is equal to the face value of the paper money. Therefore, the act of conversion of a paper money into gold cannot be "one form of obligation [of debt]", because the gold coin represents the full value of the paper money and not an IOU of the government.

Innes writes, "The object of commerce is the acquisition of credits." [Innes 1914, p. 168]. Innes is right if he means wealth by the term "credit"; but is wrong if he means debts of third person by the term credit. Because, nobody wants just to sell forever and accumulate third party's debt (IOUs) without redeeming 
those IOUs into wealth; because purpose of selling something is to get another kind of wealth for consumption instantly or at a future date.

The ultimate goal of Innes is to control inflation. He thinks excessive creation and supply of money leads to inflation. Innes writes, "Large reserves of "lawful money" in the banks are evidence of an inflation of the government currency. The inflation of government money induces a still greater inflation of credit throughout the country, and a consequent general depreciation of money. The depreciation of money is the cause of rising prices." [Innes 1914, p. 168] Therefore, to control inflation, Innes thinks that some money should be regularly drained out circulation. Innes thinks that draining of money can only be done if some people are made to pay tax to the government. Innes expresses his concern thus: "The issue of coins in exchange for gold at a fixed and excessive price, without providing taxes for their redemption, causes an inflation of government money, and thus causes an excessive floating debt and a depreciation of government money." [Innes 1914, p. 168] The goal of controlling inflation can be achieved if a theory can be framed to drain money out of circulation. Innes did exactly the same by suggesting that tax is a debt that must be redeemed by payment of money to the state. Therefore, Innes asserts that payment of tax is not a burden but a blessing. He writes, "We are accustomed to consider the issue of money as a precious blessing, and taxation as a burden which is apt to become well nigh intolerable. But this is the reverse of the truth. It is the issue of money which is the burden and the taxation which is the blessing." [Innes 1914, p. 160]

However, Innes confuses us by asserting that issuing of money is a burden. The government helps the producers cum sellers by buying their commodities with money. Therefore, issuing of money is not a burden but blessing; money acting as a medium of exchange helps distribution of products (distribution of products is the primary function of economic activities). Tax is not blessing, as Innes wants us to believe. Tax deprives people from consuming their hard-earned wealth. Besides, increase in purchasing by the government or increase in selling by the producers is a necessity so that people can earn money and buy what they want to consume.

However, Innes is wrong in asserting that, "The issue of coins in exchange for gold at a fixed and excessive price, without providing taxes for their redemption, causes an inflation of government money, and thus causes an excessive floating debt and a depreciation of government money." [Innes 1914, p. 168] If government buys by paying the real price (market value) of goods and services, then inflation cannot occur. Besides, taxation is not the proper way to reduce inflationary effect, because taxation deprives people from what they deserve as their own. Therefore, taxation is a wrong tool to reduce inflation.

Then why Innes feels it necessary to redefine money as debt. Innes himself could not grasp that. He writes, "But even when we have grasped this truth ("the basic theory that a sale and purchase is the exchange of a commodity for a credit and not 'for a piece of metal or any other tangible property. In that theory, lies the essence of the whole science of money."), there remain obscurities which in the present state of our knowledge cannot be entirely eliminated. What is a monetary unit? What is a dollar? We do not know. All we do know for certain - and I wish to reiterate and emphasize the fact that on this point the evidence which in these articles I have only been able briefly to indicate, is clear and conclusive-all, 1 say, that we, do know is that the dollar is a measure of the value of all commodities, but is not itself a commodity, nor can it be embodied in any commodity. It is intangible, immaterial and abstract. It is a measure in terms of credit and debt." [Innes 1914, p. 159] 
Thus, redefining money as the debt of its issuer (government) does not in any way help to understand clearly what money is or what is the functions of money; or in no way improves the monetary or the economic situation. On the contrary, defining money as debt blurs our vision in understanding what money is. However, The MMT uses this self-contradictory and self-defeating view of money as third party's debt (when we buy) and as the creditor's debt (when we pay tax) in support of their theory of "taxbased chartal money".

\subsection{State theory of money:}

State theory of money can be best understood if we first know the mainstream/ traditional/ orthodox / Metallist view about how money originated, what money is and what the functions of money are. According to orthodox view, money originated as a medium of exchange. Exchange "was initially conducted on the basis of barter, with individuals trucking their goods to the local trading venue and attempting to exchange what they brought for what they wanted. Thus, barter exchange required the famous 'double coincidence of wants' so that two-party exchange could only occur if each of two individuals wished to exchange that which they possessed for that which was offered by another. Money is said to arise spontaneously in the private sector in order to eliminate some of the inefficiencies of barter. Thus, society agrees upon some means of exchange called 'money' in order to overcome some of the transaction costs associated with barter." [Bell, April 1998, p.1] Regarding what is money, The Mainstream/ "The Metallists maintained that society settled on a metallic currency (gold, silver, etc.) so that the money would have (intrinsic) value. The Metallists believed that money's ability to fulfill the medium of exchange function depended "on its being a commodity with an exchange value independent of its form as currency" (Ingham 1996, p. 512) This, it was argued, was necessary in order for 'real' analysis to proceed; that is, there had to be an independent exchange ratio for every commodity (including money) with every other commodity. As a producible commodity, money was really no different from any other commodity; it merely represented the exchange of any producible commodity for any other producible commodity (Davidson, 1997). Thus, the Metallist theory suggests that problems in coordinating trade within a barter economy naturally led society to settle on precious metals as a medium of exchange." [Bell, April 1998, p.1-2] Bell writes, "Aristotle clearly supported the Metallist theory put forth so far, claiming that: "for the purpose of barter men made a mutual compact to give and accept some substance of such a sort as being in itself a useful commodity ... finally . . . impressing on it a stamp in order that this might relieve them of having to measure it; for the stamp was put on as the token of the amount" (quoted in Goodhart, 1996, Appendix B)" [Bell, April 1998, p. 2] Regarding the function of money, mainstream economists view is that "Money is a matter of functions four, a Medium, a Measure, a Standard, a Store." [William Jevons (1875) famously defined money as having four functions and his ideas inspired Alfred Milnes to write this couplet in his book 'The Economic Foundations of Reconstruction' (1919)]

However, the later mainstream economists like Samuelson refer money not only as commodities but also as other non-commodities. He wrote, "Inconvenient as barter obviously is, it represents a great step forward from a state of self-sufficiency in which every man had to be a jack-of-all-trades and master of none ... If we were to construct history along hypothetical, logical lines, we should naturally follow the age of barer by the age of commodity money. Historically, a great variety of commodities has served at one time or another as a medium of exchange: ... tobacco, leather and hides, fur, olive oil, beer or spirits, slaves or wives ... huge rocks and landmarks, and cigarette butts. The age of commodity money gives 
way to the age of paper money. ... Finally, along with the age of paper money, there is the age of bank money, or bank checking deposits." [Samuelson 1973, pp. 274-276] Here, Samuelson mentions commodity money (like gold and silver), token money (backed by commodity like gold and silver) and fiat money (paper-money which is neither a commodity nor represents any commodity) as money. This led to the problem of identifying what money really is: is it commodity with intrinsic value of its own or non-commodity fiat money having no intrinsic value.

Orthodox/ Metallist theory explains that commodity began to be universally accepted after the problem of its identifiability is resolved when an authority like the government stamped on it declaring its purity and weight. "It is not always clear whether the precious metals used in exchange were in an 'unworked' state or whether they had been minted/coined; however, Goodhart notes that exchange using unworked precious metals is more like barter exchange than monetary exchange and that payments in this form have been extremely rare because it would be difficult to 'identify' the quantity and quality of the metal (1996). This 'identifiability' problem usually meant that commodity money required a stamp or guarantee before it could circulate widely." (quoted in Goodhart, 1996, Appendix B) But it is not always clear who performed this minting function - private individuals/institutions or the government/public sector. Goodhart points out that the minting function has most frequently been performed by government (1996)." [Bell, April 1998, p. 2]. "For them [the Metallists], the State's role would have been limited to an "ex-post codification of social customs" (Laidler, 1987, p. 21). Thus, governments could encourage the continued use of metals by vouching for the integrity of the precious metals (the quality and quantity of metal), but their power would have been limited to supporting the will of the private sector. With the 'identifiability' problem resolved, metallic coins were accepted as a medium of exchange because their precious metal content gave them value independent of their form as currency. In other words, metallic coins were accepted because they were themselves valuable commodities with certain properties which made them a convenient medium of exchange.” [Bell, April 1998, p. 2]

However, the Heterodox economists view that as fiat money is not backed by any commodity so money is nothing but a numeraire. Bell writes, "The Metallist vision easily adapted to the use of non-'pure' commodity or paper money. It was argued, for example, that non-'pure' metal coins could be substituted for commodity money because their metal backing would imbue them with value. Similarly, bank- or State-issued paper currency, under a metal standard, would be accepted because of its gold or silver backing. Thus, the Metallists retained the basic logical structure of their analysis by maintaining a link between these (fiduciary) currencies and precious metals (Ingham, 1996). When, from time to time, governments suspended convertibility, and paper continued to substitute for commodity money, the Metallists maintained that the currency retained its value because people expected convertibility to be restored." [Bell, April 1998, p. 2] While, according to Metallists, "people were supposed to hold commodity money as "a medium of exchange that also [had] use as a consumption good or a productive input, at least potentially"' [Bell, April 1998, p. 2] it is not convincing why people began to accept "“'fiat money is "a medium of exchange that will never be used as a consumption good or a productive input" (Kiyotaki and Wright, 1987, p. 5; quoted in Bell, April 1998, p.2] Why "the community did continue to accept intrinsically worthless paper currency after the elimination of a metal standard left a problem for Metallists/Monetarists to explain." [Bell, April 1998, p. 2] "Perhaps the most famous 'solution' came from Walras who suggested that money could be reduced to a pure number, the numeraire. Money was to be viewed as nothing more than a representation or a symbol of 'real' goods; its development was irrelevant. 
As a numeraire, money was brought into the analysis only to allow the 'auctioneer' to announce prices (money numbers) in order to bring about market-clearing equilibrium.” [Bell, April 1998, p. 3]

Thus, there are differences of opinions between the mainstream economists and the Heterodox economists regarding whether money is commodity of self-content value or just a numeraire and whether money is stamped by "private individuals/ institutions or the government / public sector" for its 'identifiability', the MMT chose the theory that money is a numeraire (not as commodity)/ 'fiat' money and chose government (not private individuals/ institutions) as authority for stamping money for making it 'identifiable'. Thus, basic frame of MMT was created; that government creates money as a numeraire (not a commodity) having no intrinsic value.

However, some questions still remain and that have to be answered. One question is if money is a numeraire (not a commodity), then from where does it get its value or why it is accepted. The MMT answers this question by inventing a theory that money gets its value from the state's (government's) declaration that it will accept money in its pay-offices and the value of the units written on the money is determined also by the proclamation of the state that the units will be valued in terms of so and so units of commodities. "the Metallists were unable to convincingly cope with. The paradox - why should paper with no value continue to circulate? Recall that the early Metallists traced money's value to its precious metal content/backing but that modern money (inconvertible State or bank money) provides no such basis for value. The solution to the paradox, as Smith recognized, is that the paper is not without value!" [Bell, April 1998, p.3] Adam Smith explained, ""A prince, who should enact that a certain proportion of his taxes should be paid in a paper money of a certain kind, might thereby give a certain value to this paper money" ([1776] 1904, p. 312)"'” [Bell, April 1998, p. 3]

Stephanie Bell, one of the most veteran MMT economists explains how Adam Smith's view matches the views of the MMT thus:

"Smith's theory, unlike the Metallists', can be applied equally convincingly whether the medium in which taxes are due is fiat money, paper backed by a precious metal, or commodity money. Whatever the prince announces he will accept in payment of taxes will immediately imbue this medium with value for it will be demanded as a means of discharging the tax liability.

Thus, irrespective of any inherent property or function they may come to serve, the value of these monies depends on their usefulness in settling tax or other liabilities to the State." [Bell, April 1998, p.3] "the 'Anti-Metallists' or Chartalists see the creation of money as contingent upon the State's proclamation that a certain currency will be accepted by the State at face value. Thus, State money is created when the public agrees to hold (as an asset) state-issued currency (a liability to the State) which is required in payment of taxes. The Chartalist vision supported by Minsky is, therefore, consistent with his treatment of money as a two-sided balance sheet operation." [Bell, April 1998, p. 6, Italics added]

Friedrich Knapp (from whom the MMT got the idea) in his book "The State Theory of Money" states that, ""[T]he money of a State is . . what is accepted at public pay offices" and "the standard is not chosen for any properties of the metals" [Knapp, 1924, p. viii]. And the values of the money will be determined by the 'conversion rate' proclaimed by the state. Kelton writes, "When, for example, the State announced that it would accept coined gold in payment of taxes, it also had to announce a nominal conversion price for gold. That is, the State had to tell its constituents how much of their nominal tax 
liability could be eliminated with gold. The State could announce that one ounce of coined gold will eliminate $\$ 35$ of one's tax liability. The coin, whether stamped 'one ounce' or ' $\$ 35$ ', will reduce one's nominal tax liability by $\$ 35$, regardless of its weight, at the time it is presented at State pay offices. Thus, it is the conversion rate, determined by proclamation, not its precious metal weight that determines its validity as a means of payment at State pay offices." [Bell, April 1998, p.5] Thus, MMT tried to establish that whether money contains any metal or not is irrelevant for how much value should the money carry. They suggest that "the State can make anything it chooses (metal coins, paper backed by some metal, or inconvertible paper) generally acceptable by proclaiming that it will be accepted at State pay offices. What makes a currency valid as money is a proclamation by the State that it will be accepted at its pay offices" [Bell, April 1998, p. 4]. Kelton also writes, "Smith, Knapp, Keynes and Minsky recognized the State's power to demand certain payments from its constituents (taxes, fines, etc.) as well as the power to determine both the unit in which these liabilities are denominated and the means by which they may be discharged. They also understood that the value of certain money derives from its acceptance at State payoffices, not from any inherent value within/backing the currency itself. That is, support for the Chartalist vision of money as a 'creature of the State' can be found in each." [Bell, April 1998, p. 5] Therefore, state's money gets it value from the need that tax must be paid in state's money. Minsky writes, "the fact that taxes need to be paid gives value to the money of the economy." [Minsky 1986, P. 231] Thus, a state theory of money (MMT subscribe to this theory) is formulated. Thus, "Chartalist (state) theory does not view money as a commodity with exchange value, scarcely different from any other commodity. ... On the contrary, Chartalist (state) theory seeks to uncover the essential properties of money as a unit-ofaccount and a means of payment." [Bell, April 1998, p.3]

Wray, one of the chief protagonists of the MMT, explains the 'state money' thus: "For the past four thousand years ("at least", as John Maynard Keynes put it), our monetary system has been a "state money system". To simplify, that is one in which the state chooses the money of account, imposes obligations denominated in that money unit, and issues a currency accepted in payment of those obligations. While a variety of types of obligations have been imposed (tribute, tithes, fines, and fees), today taxes are the most important monetary obligations payable to the state in its own currency." [Wray June 2014, p-2] Wray wrote, "Our system is a state money system. Our currency is government's liability, an IOU that is redeemable for tax obligations and other payments to the state. The phrase "debt-free money" is based on a misunderstanding. Remember, "Anyone can create money", the "problem is to get it accepted". They are all IOUs. They are either spent or lent into existence. Their issuers must accept them in payment. They are accepted by those who will make payments, directly or indirectly, to the issuers." [Wray June 2014, p. 7]

However, the MMT's arguments are arbitrary. The MMT, without trying to explain the ambiguities regarding whether money is commodity of self-content value or just a numeraire and whether money is stamped by "private individuals/ institutions or the government / public sector" for its 'identifiability', tries to mislead us by reducing the authority of creating money to the state and by suggesting that the money (metal coins, paper backed by some metal, or inconvertible paper) gets its value not from its metal (commodity) content but from state's declaration of what value an unit of money will carry. However, the fact is that no coined money got their value from any proclamation from their creators (either the states or the bankers). 
Bell writes, "If, however, their [money's] validity is retained after their wearing down has been noticed, then their continued use is in accordance with proclamation and they are Chartal" [Bell, April 1998, p. 4] However, the following quotation from Kelton does not match with their claim that money gets its value from the proclamations of the government. Kelton writes, "To understand why the State objected to the debasement of precious metal coins, we must understand the reason for taxation. The purpose of taxation is to get people to work and produce for the State. That is, the State wants bridges, armies, etc. and gets the private sector to produce them by imposing taxes. To pay the taxes, the private sector must acquire the State's money. By debasing coins, gold could be brought to the mint, coined, and exchanged against the unit of account in order to reduce one's tax liability. The community, then, would have been able to satisfy their nominal tax liabilities by producing less for the State." [Bell, April 1998, p. 4] This statement clearly reveals that value of coin was measured at par its metal-content (and not by proclamation). Otherwise, tax-payers could not use [debased] coined gold ('clipped' or 'shaved') "to reduce [their] tax liabilities." [Bell, April 1998, p. 4] and precisely that is "why the state objected to the debasement of precious metal coins." [Bell, April 1998, p. 4]

If a full-bodied gold coin was clipped or shaved up to $50 \%$, the value of the coin would reduced also to $50 \%$ of its market value with regard to its exchangeability with other commodity or services. Therefore, it is wrong to accept "their (debased coins) validity retained after their wearing down has been noticed" and that "their continued use [is] in accordance with proclamation". [Bell, April 1998, p. 4] The fact is that all coins (either issued by the government or by the individual bankers) were/ are accepted and valued at par their commodity (metal) content.

Now, the question remains, why the fiat moneys were/ are accepted and how they were/ are valued. The answer is not what the MMT suggests that fiat moneys get their value from proclamations of their creator (the King, according to MMT); but because they were/ are accepted as the user/ holder of the fiat moneys believed that the creator must have the reserve in their custody the commodity (gold or anything) that corresponded / corresponds to their face value. It is the fraudulence on the part of the creators (kings or bankers) that they created/ creates money without keeping any reserve against the fiat moneys. That is no fault of the users/ holders. When it was revealed/ reveals that the creators of money (either the kings or the bankers) were/ are insolvent, the people refused / refuses to use that fiat money.

From the above discussion, it is clearly proved that the MMT's assertion that money is a "creature of the state" and that money gets its unit-value and acceptance from the proclamation of its creator (the king, in the past and the government, at present) and that money is nothing but a numeraire (number) having no intrinsic value and that money is debt of its issuer (the state or government) is fallacious, unrealistic and a hoax. Therefore, the claim of the MMT that, "in practice in all modern monetary systems, the state plays an active role in the monetary system. It chooses the unit of account; it imposes tax liabilities in that unit; and it issues the money thing that is used by private markets for ultimate clearing. Any story of money that leaves out an important role for the state represents little more than fantasy, a story of what might have been, that sheds little light on the operation of real world monetary systems" [Tymoigne and Wray July 2005, p. 19] is itself a fantasy and not the real world monetary system. 


\subsection{Theory of Hierarchy of Money:}

The very phrase the "hierarchy of money" tells that there are many types of "money" and their statuses are unequal. This is because MMT distinguishes between a 'money of account' and 'money'. According to Keynes, "the money of account is the description or title and the money is the thing which answers to the description" (Keynes 1930, p. 3). "if the same thing always answered to the same description, the distinction would have no practical interest. But if the thing can change, whilst the description remains the same, then the distinction can be highly significant" (Keynes 1930, p. 3). As different things answer to the description of the 'money of account', so there exists, what Minsky calls, a "hierarchy of monies". [Minsky 1986, p. 228] The 'title' or 'description' to which all money in the hierarchy must answer is, according to Chartalist theory, that money is a 'creature of the State', dollar that is the state's currency in the USA. Therefore, in the USA, all types of moneys that are accepted and circulated are denominated in dollar units. According to MMT, “"'the unit in which State money is denominated and in which taxes are due determines the unit of account for all money in the hierarchy" (Keynes, 1930; Lerner, 1947; Wray, 1997)'"'. [Bell April 1998, p. 6] Bell explains how and why state money is regarded as the highest form of money in the hierarchy. She writes, "It is fairly easy to see how the State's liabilities/promises may come to serve as a means of payment and a medium of exchange in private transactions. As Lerner recognized, the modern state can, by accepting it at its pay-offices, "make anything it chooses generally acceptable as money" (Lerner 1947, p.313). He stressed that it is not their status as legal tender but their acceptance in payment of taxes that makes the State's promises the most acceptable/liquid money in the hierarchy. He maintained that it is not enough for the State to simply declare that something is money (i.e. to define it as legal tender) for "its general acceptability, which is its all-important attribute, stands or falls by its acceptability by the state" (Lerner, 1947, p. 313).” [Quoted in Bell April 1998, p. 8]

However, all the 'thing's (money) that are denominated in dollar are not of equal status. "Recall that money represents a promise to pay/IOU and that these promises can be created by anyone. The "secret" to turning these promises into money is getting other individuals or institutions to accept them. Therefore, the 'hierarchy of money' can be thought of as a multi-tiered pyramid where the tiers represent promises with differing degrees of acceptability (Foley, 1987)." [Bell April 1998, p. 6] In this hierarchical system, the money (IOU) of the lower order will be converted into money (IOU) belonging to any higher order of the hierarchy. Bell explains this system thus: "We can consider the group of potential promise-makers to be: the government, banks, firms (non-bank) and households. When a firm makes a promise (issues, say, commercial paper), it promises to convert this promise, on some specified date, into a bank's promise, a demand deposit. Likewise, when a household makes a promise (issues debt to, say, a credit card company), it promises to convert its promise into a bank's promise. In the above, the "secret" to getting household and business debts accepted is a proclamation that they are convertible - at least potentially into the promise of someone higher in the pyramid. Commercial paper, bonds, and credit card debt will (assuming the issuer does not default) be retired by delivering the promise of a bank." [Bell April 1998, p. 7]

However, state money (one kind of "money of accounts"), into which all "money-things" must finally be converted, need not be converted into any higher form of money (IOU) because there is no higher form of 'money of account' than the state money. Bell explains, "This condition [of convertibility into higher forms of money/ IOUs] does not, however, apply to all money in the hierarchy. Unlike households and firms, State promises and certain bank promises would be accepted even if they were not convertible into 
anything else. Even though, today, banks make their promises (demand deposits) convertible, on demand, into the State's promises (government money), this is not the reason they are accepted. It is because bank money is accepted at State pay-offices that it, along with State-issued currency, is considered by Knapp to be the 'decisive' money of the system." [Bell April 1998, p.7] Quoting Foley, Bell argues, "As Foley noted, "the State does not have to pay its liabilities by transferring something else" (Foley 1987, p. 520). Thus, neither the State nor the banks rely on convertibility for acceptance of their promises; what makes them both acceptable is not convertibility into something else but acceptance in payment to one's creditors." [Bell April 1998, p. 7] Bell also writes, "Although the State's liabilities reign supreme among promises, certain bank promises, as a consequence of their acceptance at State pay-offices, also come to serve as means of payment and media of exchange. In particular, "[d]emand deposits have attained a special status in our economy because of the special role commercial banks have come to play" (Wray, 1990, p. 291)". [Bell April 1998, p. 8] These three quotations from Bell clearly prove that, according to MMT state money and bank money are in the highest order in the hierarchy of money and these two types of money need not be converted into any higher form(s) of money as there is no higher forms of money (IOU) issued by any higher authority than the state and as they are directly accepted in the public payoffices.

The degree of acceptability of different kinds of money determines their rank/ order in the hierarchy of money. Because of their highest degree of acceptability the state money and the bank money are in the apex of the hierarchy. Bell writes, "Recall that a money's place within the hierarchy depends on the degree to which it is accepted by society. As the 'decisive' money of the system, both the State's promises and banks' promises rank high among the monies of the hierarchy." [Bell April 1998, p. 7] Next in the hierarchy of money (second tier in the pyramid) comes the money issued by the commercial bank. Bell writes, "Because the central bank guarantees that demand deposits [created by commercial banks] will trade at par with government currency and because they are accepted in payment of taxes, bank promises (demand deposits) are nearly as liquid as State money and therefore occupy the second tier in the pyramid.” [Bell April 1998, p. 8]

Degree of acceptability (rank in the hierarchy) of moneys depends on the degree of their liquidity. If money is more readily converted into money higher in hierarchy without loss of any value, then that money is more liquid (more acceptable) than the money which is less liquid (therefore less acceptable) . According to MMT, "The promises of firms and households occupy the third and fourth tiers, respectively. This is because there is at least some chance that they will not be traded at par with government money (which is needed to pay taxes). For example, a firm may sell bonds to finance the purchase of a new plant. Although the firm promises to pay a certain nominal amount to the holders of these bonds, their value may vary over time or place to place (for example, with default risk and/or as interest rates change). Thus, as assets to their holders, these bonds will be less liquid than bank money because they can not necessarily be "quickly converted into the medium of exchange with little loss of value" (Wray 1990, p.16; my emphasis). Still, firms' promises are more readily convertible into the medium of exchange (i.e. are more liquid) than households' promises because better secondary markets exist for their resale. To get business and household debts accepted, they might be made convertible into the debt of someone higher in the pyramid and may also require interest payments to compensate for the risk associated with holding less liquid assets.” [Bell April 1998, p. 8] 
Besides, the kinds of moneys described above, there are other types of moneys that are the least liquid and acceptable. Wray writes, "MMT talks about a "money pyramid", with the state's own currency at the top. Bank "money" (notes and deposits) are below the state's "money" (reserves and currency). We can think of other financial institution liabilities as below "bank money" in the pyramid, often payable in bank deposits. Lower still we find the liabilities of nonfinancial institutions. And at the bottom we might find the IOUs of households-again normally payable in the obligations of financial institutions." [Wray 2015, p-5] Bell argues, "When, for example, the postal service proclaims that a $\$ 0.32$ stamp will be accepted as payment for delivery of a small envelope, an individual/institution must agree to hold the stamp (to accept the stamp as the debt of the postal service) in order for it to become Chartal money." [Bell April 1998, p.6] She continues, "Going back to Keynes, then, a great number of 'things' will answer to the 'description' or 'title' of money. That is, every plane ticket, pre-paid phone card, movie ticket, subway token, etc. is a form of Chartal money. One could anticipate the disaster ahead if we were planning to describe the 'hierarchy of money' in detail." [Bell April 1998, p.7]

However, these things like postage stamp, "every plane ticket, pre-paid phone card, movie ticket, subway token, etc." cannot be treated as money, because according to MMT, "all money is a 'ticket' or 'pay-token' which gains validity by proclamation that it will be accepted as a means of payment. These 'tickets' or 'tokens' which individuals/institutions have proclaimed acceptable as a means of payment do not become money until they have been accepted by another individual/ institution." [Bell April 1998, p.6] However, none of these things ("every plane ticket, pre-paid phone card, movie ticket, subway token, etc.") are "accepted by another individual/ institution" and, therefore, cannot be treated or accepted as money as Bell wants us to accept.

The MMT is distorting the history of money by suggesting that in modern time money is issued by the state. However, though state used to issue money in the past but that money was either a commodity or token (certificate of commodity) money. Now-a-days, state does not issue money. Therefore, considering money as a creature of state is a colossal blunder.

The MMT takes double standard in explaining the status of state money (IOU) on one side and other monies (IOUs) that are issued by banks, firms and households, on the other side. MMT argues that the hierarchy of monies of different issuers depends on their convertibility into higher forms of money (IOU). Thus, "To get business and household debt accepted, they might be converted into the debt of someone higher in the pyramid." [Bell April 1998, p.8] But, MMT exempted state money from being converted into any money higher in the pyramid of hierarchy, because there is no higher authority than the state that issues money (IOU). MMT explains that state money does not need conversion into any higher forms of money. According to MMT, the state money, to be accepted, needs the power of the state to pass state's debt to the taxpayers as their tax-debt. Moreover, while other monies are not accepted for payment and as medium of exchange, MMT argues that state money, even if it is not convertible, is accepted for payment and medium of exchange. Again, while issuers of other monies (IOUs) must pay interest to the holder of their IUOs, the state is not liable to or must not pay any interest against its money (IOU) to the holder of its IOUs. MMT also argues that other monies (IOUs) cannot be redeemed through payment but can be converted into higher forms of money (IOU). Only the state money can be redeemed through tax payments. Therefore, to be redeemed, the other monies must first be converted into higher forms of money. Thus, MMT takes double standard to pass the state money as an IOU (IOUs cannot be used for full and final payment), and at the same time, to pass the same state money as an instrument that is used 
for full and final payment. MMT failed to realize that only the money that has its intrinsic value can be used for medium of exchange and for full and final payment. However, according to MMT, the state money (state's IOU) is nothing but a numeraire (number) having no intrinsic value. The MMT assigns these dual characters to the state money to establish their theory that state money is nothing but an IOU (debt instrument) of the state and at the same time to pass the state money off as real money (not an IOU) that is used for payment and as medium of exchange. This is a duality or inconsistency on the part of the MMT.

The MMT fails to realize that what they term as money (IOU) issued by issuers of different hierarchy is not money at all; they are IOUs of their issuers. If none of those monies (including the state money) is redeemable then they are nothing but IOUs of their respective issuers. If moneys (IOUs) other than state money are not accepted as medium of exchange for full and final payment, and if they can be accepted only if they are redeemed into the highest form of money (that is state's IOU) then they can at most be considered as claims (IOUs issued against the state money) on the state money. And IOUs are not money at all. Besides, in modern economy no entity (even the state) other than the central bank can create money. Therefore, there is no state money as the MMT claims it to be there in a state. The whole foundation (argument) of the MMT that state money is the supreme is a hoax and is not a reality. There is only one type of money that is issued by the central bank; and the state, for its spending, depends on the money that it gets through taxation and borrowing (selling bonds) from the non-government sector. The central bank does no more lend money directly to the government in any country. Only the money issued by the central bank is real money, other moneys (IOUs) in the hierarchy are only IOUs and not money at all.

As there is no money other than the central bank money, so any hierarchy of money cannot exist.

\subsection{Theory relating to Taxes and Bonds:}

Wray writes, "While many people believe that a government's spending is constrained by its ability to collect taxes and sell bonds ("borrow") that is actually not correct for a sovereign government." [Wray, 2006, p. 7] Stephanie Bell also writes, "there is another, more powerful, method by which to argue that taxation and bond sales should not be considered financing operations" [Bell July 1998, p.20]

The MMT argues, "After carefully considering the complexities of reserve accounting, it is argued that the proceeds from taxation and bond sales are technically incapable of financing government spending and that modern governments actually finance all of their spending through the direct creation of highpowered money. The analysis carries significant implications for fiscal as well as monetary policy." [Bell July 1998, p Preface] "Modern governments, then, finance all of their spending through the direct creation of new (high-powered) money." [Bell July 1998, p. 22] Wray argues, "Another shocking truth is that a sovereign government does not need to "borrow" its own currency in order to spend. Indeed, it cannot borrow currency that it has not already spent! This is why MMT sees the sale of government bonds as something quite different from borrowing." [Wray June 2014, p-3] "Government never needs to sell bonds before spending, and indeed cannot sell bonds unless it has first provided the currency and reserves that banks need to buy the bonds." [Wray June 2014, p. 4] "Indeed, if government spends and lends currency into existence, it clearly does not need tax revenue before it can spend. Further, if taxpayers pay their taxes using currency, then government must first spend before taxes can be paid. Again, all of this 
was obvious 200 years ago when kings literally stamped coins in order to spend and then received their own coins in tax payment." [Wray 2015, p. 2]

\subsubsection{Tax:}

The MMT argues that though for spending government does not need receipts from tax, yet imposition of tax by the state on its subjects has various other purposes.

(A) Taxes redeem the money (government's debt): The MMT argues that "Government imposes a tax obligation" [Wray 2015, p-5] because, payment through tax is necessary to redeem government's debt obligation that the government itself creates through spending money. "When the sovereign issues currency, she/he becomes a debtor. The sovereign's currency is debt. The holder of the currency is the creditor. The most fundamental promise made by any debtor is the promise to redeem, by acknowledging his/her debt and accepting it. Those who themselves have debts to the sovereign can submit the sovereign's debt in payment." [Wray Nov. 2016, p. 8] "Currency must be debt and it must be redeemed to have a determinant nominal value in terms of the domestic money of account. The sovereign might make other promises when she/he issues debt. There could be a promise to pay interest over time. There could be a promise to redeem her/his debts for the debts of other sovereigns. While uncommon even in history, the sovereign could also promise to redeem for precious metal bullion. These are additional promises but are not necessary to create a demand for the sovereign's currency" [Wray Nov. 2016, p.8] "taxes redeem the currency. All issuers of IOUs must stand ready to redeem them." [Wray, 14 May 2014, p. 3] He writes, "In other words, what "stands behind" the state's currency is the tax system, and the state's obligation to accept its currency in tax payment." [Wray, 2010, p. 44] "Taxes are for redemption, not to generate revenue "income" to be spent - as Beardsley Ruml put it." [Wray 2019 Oct, p.10]

However, nowadays, government does not create money. Again, previously, when the government could create money, it would not create money as debt; it would create either commodity money or create token money (paper money) against its bullion reserve.

The MMT argues that "It must also be recognized that when currency or reserves return to the State, the liabilities of the State are reduced and high-powered money is destroyed. ... the State, once it fulfills its promise to accept its own money (HPM) at State pay-offices, can eliminate an equivalent number of these liabilities from its balance sheet." [Bell July 1998, p. 21] "I have argued that the sovereign imposes debts - tithes, fees, fines, and taxes - on the population. Those with tax debts can redeem themselves and wipe clean their tax debt by delivering back to the sovereign her/his tallies, coins, or paper notes. Today it is actually done with keystrokes - debits to private bank deposits and the bank reserves at the central bank." [Wray Nov. 2016, p. 10]

However, this argument of the MMT is wrong. Just paying tax to the government will not redeem the government's debt; to redeem its debt, the government must repay the debt that it owes to its bondholders. Besides, "tithes, fees, fines, and taxes" are not debts; they are obligatory payments to the state. Fines are punishments for doing any wrong. Tithes, fees, and taxes are payments against the services that we receive. Against the payments of tithes, we get religious services. We pay fees against some services. Against tax-payment, the government gives us protection, maintains law and order and does various public works.

Wray argues, "Note that we still say that we have filed our "tax return" when we pay taxes. What did we "return"? We returned to our sovereign government its own currency (along with a statement showing how much we owed). In the old days, we would "return" to government its coins, tally sticks, paper 
money, and other forms of currency in order to meet our tax obligation" [Wray 2015, P-2] Here, the MMT is wrong in understanding that Hazelwood tally sticks were used as money for paying tax to the state. What Wray did not explain is that tally sticks would not be accepted as returned unless and until the commodities that were written on the tally sticks were paid to the government.

Besides, we do not return just currency or money to the government as tax; we transfer our right to the commodities that we could buy with that money or currency to the government. If we pay tax in coins, we transfer our right to the commodity of which the coin is made. If we pay paper money or other forms of money as tax, we transfer to the government our right to that commodity or reserve against which the Money Issue Department had issued that money. What we pay as tax is just not the paper money that has almost no value; we transfer the right to that commodity that we could buy against the face value of the paper money. Therefore, it is not "returning" of what the government issued as currency or money; it is paying that commodity which we could buy against the money.

(B) Tax prevents inflation: Another reason for imposition of tax obligation, according to MMT, is to reduce inflation. "Taxes remove currency from circulation; this has long been recognized as a way to prevent currency issues from causing inflation." [Wray Nov. 2016, p. 9] However, this statement is contradictory. Removing currency from circulation to prevent inflation and preventing currency issues to prevent inflation are not same.

Besides, if government purchases with its IOU and if purchasing by government is the only way to inject money (IOUs of the government) into the economy, then, inflation can only happen if government itself buys goods and services at the price above the normal price. Again, if government purchases are at par the normal price and /or if the purchases are done above normal price, in both cases, it is crime on the part of the government to force the sellers to pay back their hard-earned money to the state as tax, only on the pretext that currency must be removed from circulation to prevent inflation, if there remains no other strong ground for paying tax. The fact is that government receives tax so that it can spend for public purposes. If tax redeems the government's debt and removes money from circulation to reduce inflation, then all money must be removed from circulation so that government's debt is fully redeemed and no inflation can occur. Wray knows that removing all money from circulation will have catastrophic effect on the economic activities. Therefore he argues, "However, it is not necessary to remove all the issued currency through taxes. Some will continue to circulate to facilitate private transactions. Some can be accumulated as net saving. And some can be "redeemed" for bonds should the treasury decide to sell them." [Wray Nov. 2016, p. 9]

(C) Tax drives currency: According to Bell, "taxes can be viewed as a means of creating a demand for the government's money, HPM." [Bell July 1998, p. 20]. "Since it is the law that individuals must pay taxes, they must (assuming they wish to avoid punishment) acquire the State's money. In a sense, the State, unlike any other issuer of promises, can 'force' the acceptance of its liabilities; in order for the taxpaying population to settle their obligations to the State, they must accept the State's money." [Bell April 1998, p. 7] Wray writes, "we have argued that "taxes drive money" in the sense that imposition of a tax that is payable in the national government's own currency will create demand for that currency. Sovereign government does not really need revenue in its own currency in order to spend. ... Spend first, tax later is the logical sequence." [Wray 15 May 2014, p. 1] Wray states, "Our meme: taxes create a demand for the currency, ensuring willing sellers of goods and services for money". [Wray, Nov. 2012, p. 10] Wray writes, "MMT says that the main purpose of the tax system is to "drive" the currency. One of the reasons people will accept the sovereign's currency is that taxes need to be paid in that currency. 
From inception, no one would take currency unless it was needed to make payments. Taxes and other obligations create a demand for the currency used to make obligatory payments. From this perspective, the true purpose of taxes is not to provide "money revenue" that government can spend. Rather, taxes create a demand for the government's own currency so that the government can spend (or lend) the currency." [Wray 2015, p-5] "We conclude that taxes are necessary from inception to "drive the currency" (that is, to create a demand for it) and - perhaps - to redeem the currency, withdrawing potential aggregate demand to keep inflation at bay. But not for revenue". [Wray 2019 Oct, p.10] "Taxes or other obligations (fees, fines, tribute, tithes) drive the currency. The ability to impose such obligations is an important aspect of sovereignty; today, states alone monopolize this power. This comes from Knapp, Innes, Minsky, and Mosler." Wray 2018 Oct. p.3] "From inception, the tax liability creates people looking for paid work...in the government's currency. The government...then spends its currency into existence, giving people access to the tokens they need to settle their obligations to the state. Obviously, no one can pay the tax until the government first supplies its tokens. As a simple point of logic, Mosler explained that most of us had the sequencing wrong. Taxpayers weren't funding the government; the government was funding the taxpayers." (Kelton 2020, pp. 26-27, bold added) [Quoted in Robert P. Murphy 2020 June 23] "MMT argues that "taxes drive money" in the sense that obligations create the initial demand for the sovereign's currency. This ensures that currency will have some value. However, MMT insists that the value is determined by what one must do to obtain the currency. If one must work for one hour to obtain $\$ 15$, that establishes the value of the currency: one hour of labor equals $\$ 15$. "[Wray July 2020, p. 31] However, the fact is that the Government spends money for purchasing but does not at all lend money.

"The government ensures a demand for its currency by imposing a tax liability that can be fulfilled by payment of its currency." [Wray, Oct 2009, p. 5] "The purpose of taxes is to create a demand for money, since only money can pay taxes and all citizens face a mandatory tax burden." [Hurford and Kaboub, 2012, p. 23] Wray states, "Our meme: taxes create a demand for the currency, ensuring willing sellers of goods and services for money." [Wray 2012 Nov, p. 10]

However, the government does not need to impose taxes to make the people accept its currency or to drive the currency. People who do not pay tax also accept the currency because they need money to use it as a medium of exchange. Besides, in the past, money issued by the private banks need not be returned to the banks as tax for its acceptance by the people.

Wray himself writes, "Private money-dominated IOUs developed for other reasons than the imposition of taxes." [Tymoigne \& Wray, Nov. 2013, p. 10] "However, it is easy to find examples throughout history in which, say, a feudal lord or an owner of a company town is able to exercise sovereign power in its jurisdiction, and hence able to "buy" through issuing its own "liabilities"." [Wray, Dec. 2001, p.14] "In the old days in the US, notes [were] issued by various banks". [Wray, June 2014, p. 4] There are monies that are not created by the government but by local banks. "The bank makes notes and offers them in payment to its customers. Issuing notes is not a special business . . . but a special way in which the bank endeavors to make its payments .... It tries to pay in its own notes instead of in money issued by the State because then with a comparatively small capital it can make greater profits than it otherwise could". [Wray, March 2014, p.6] People accept money not because they have to pay tax but because they need it for exchanging commodities. "Knapp argues that banknotes do not derive their value from the reserves (whether gold or government fiat money) held for conversion, but rather from their use in the "private pay community" and "public pay community"; this, in turn, is a function of "acceptation" at the bank and public pay offices. Within the "private pay community" (or "giro"), bank money is the primary money used in payments." [Wray, March 2014, p.7] In all these cases of privately issued monies, acceptance did 
not pose a problem because the money-issuing authorities did not or could not impose tax liability on their customers. Wray himself writes, "Private money-dominated IOUs developed for other reasons than the imposition of taxes." [Tymoigne \& Wray, Nov. 2013, p. 10]

Again, money was not the only thing that was paid as tax. Taxes were paid mostly in commodities (or wealth) by the people to the crown. State also used to spend in the form of kinds and services.

(D) Tax move resources from private sector to public sector: Another reason for imposition of tax obligation is "We've previously established that "taxes drive money". We've also established that from the perspective of the sovereign that creates the money, the purpose of the monetary system is to move resources to the public sector." [Wray, 17 June 2014, p. 1] "The purpose of the tax is to free up resources to pursue the public purpose-including anti-poverty programs." [Wray, 02 June 2014, p.3] "But why should the government need to take from the private sector the money (currency and/or bank reserves) that it alone is capable of creating? It seems reasonable to suggest that it is not money but bridges, armies, satellites, etc. that the government wants and that it acquires them by encouraging the population to provide them in exchange for government money. That is, it cannot be the government but the public/citizens who need the money in order to settle their tax liabilities to the state." [Bell July 1998, p. 19] "In other words, the government's purchase of goods and services using newly-created money must first have supplied the citizens with the means with which to pay taxes. Thus, taxes can be conceived as the means by which the government directs real resources from private to public domain. If this theory is accepted, taxes are used to create a demand for the government's money, not to "finance" the government's spending." [Bell July 1998, p. 19] "The purpose of taxation is to get people to work and produce for the State. That is, the State wants bridges, armies, etc. and gets the private sector to produce them by imposing taxes." [Bell April1998, p. 4]. "the need to pay taxes means that people work and produce in order to get that in which taxes can be paid" [Minsky 1986, p. 231] [Quoted in, Bell April1998, p. 5]

Then it is clear that tax-payment does not redeem the debt of the government that it had incurred earlier to create the money when it purchases. Those who give tax do not create "bridges, armies, satellites, etc"; they pay money as tax. The government spends the money that it gets as tax to buy "bridges, armies, satellites, etc".

(E) Taxes discourage sins: "Taxes can serve other purposes, too, as I've argued earlier in this series. We can use taxes to discourage "sins"- in which case the purpose of the tax is to eliminate "sin" so the optimal sizing of the tax would eliminate sin and hence raise no revenue at all. Previously, I argued that we can view excessive riches as a sort of "sin" that we want to tax away. ... The goal is not to raise revenue but to reduce sin." [Wray, 02 June 2014, p.4] "We've long taxed various sins. While some confuse the purpose of sin taxes, it should be clear that the purpose of taxing bads is not to "raise revenue" but to "reduce sin". We want to reduce the sin of smoking. Of polluting. Of high-speed trading." [Wray 17 June 2014, p. 3] Wray writes. "The third purpose is to discourage bad behavior: pollution of air and water, use of tobacco and alcohol, or to make imports more expensive through tariffs (essentially a tax to raise import costs and thereby encourage purchase of domestic output). These are often called "sin" taxes - whose purpose is to raise the cost of the "sins" of smoking, gambling, purchasing luxury goods, and so on." [Wray 15 May 2014, p. 3] 
However, Wray is wrong. Earning, selling, possessing wealth, eating in a hotel, etc. are not sins. But government levy tax on them. To justify his theory that the government does not need tax to be able to spend, Wray has to invent this sin theory of tax to make us believe that government levy tax only to reduce sins or crimes.

Wray writes, "It is very common to use wage taxes, sales taxes, profits taxes, income taxes, and wealth taxes in highly monetized economies." [Wray 17 June 2014, p. 2] If these are sins, then to avoid tax, people should avoid selling his products, or getting salaries against his services, or eating in a hotel. It is not possible. The Government needs funds to be able to discharge its duties. Therefore, government taxes on them who can afford paying tax. Therefore, the sin theory of tax is a vague idea.

(F) Tax reduces aggregate demand: Wray argues, "the second reason to have taxes is to reduce aggregate demand. If we look at the United States today, the federal government spending is somewhat over $20 \%$ of GDP, while tax revenue is somewhat less-say $17 \%$. The net injection coming from the federal government is thus about 3\% of GDP. If we eliminated taxes (and held all else constant) the net injection might rise toward $20 \%$ of GDP. That is a huge increase of aggregate demand, and could cause inflation. Ideally, it is best if tax revenue moves counter cyclically-increasing in expansion and falling in recession. That helps to make the government's net contribution to the economy countercyclical, which helps to stabilize aggregate demand." [Wray 15 May 2014, p. 1] Here, Wray contradicts his earlier argument that "Spend first, tax later is the logical sequence." [Wray 15 May 2014, p. 1] If government generally spends (injects money) less like 3\% of GDP than it imposes (remove money from circulation) tax like $17 \%$ of GDP, then how the people can pay the tax. Therefore, it is certain that money is not injected by the government but by some other concerns. Again, GDP comprises the aggregate circulation of money in a given period. It means aggregate demand is matched by aggregate supply that caused the aggregate circulation of money through exchanges of commodities. Therefore, aggregate demand that is satisfied by the aggregate supply and aggregate circulation (exchange) of money equals to the aggregate GDP. Therefore, whether or not the government injects less or more money by way of its purchases aggregate GDP reflects the aggregate demand; the aggregate demand is $100 \%$ of the GDP and, in this case, not $3 \%$ or $17 \%$ or $20 \%$.

\subsubsection{Government Bonds:}

MMT explains though government does not need proceeds from bond-sales for its spending, yet bondsales fulfill various other purposes:

"When a country operates on sovereign currency, it doesn't need to issue bonds to "finance" its spending." [Nersisyan, Yeva \& Wray, June 2010, p. 14] "It is also obvious that the nongovernment savings cannot exist before the budget deficit." [Wray, Oct 2009, p. 8] The purposes of selling government bonds are:

\section{(A) Bond-sale helps the Central Bank to maintain positive interest rate on lending}

"Bonds, which are used to prevent deficit spending from flooding the system with excess reserves, allow the maintenance of positive overnight lending rates. Neither taxes nor bond-sales, therefore, need be viewed as a financing operation." [Bell July 1998, P 20]. Bond sales help "maintaining positive overnight 
lending rates." [Bell July 1998, P 19] "In order to move to a positive funds rate, either the Federal Reserve or the Treasury would be forced to sell bonds to drain excess reserves.” [Bell July 1998, p. 22]

However, this is not correct. Whether or not any bond-sale takes place, the Fed can reduce or increase the overnight interest rate or any other rates of interest using its monetary tools like repo-rate, reverse-reporate, cash reserve ratio, etc. Besides, the value of money spent by the government matches the value of the goods and services that the government buys. The government does not give "excess" money that may create "excess reserve".

\section{(B) Government helps people and banks to save their excess money in bonds}

Wray writes, "Because the public will normally wish to hold some extra money, the government will normally have to spend more than it taxes, in other words, the normal requirement is for a government deficit." [Wray, Sept.1998, P 14] Bell writes, "They [bond sales] provide the private sector with an interest-earning alternative to non-interest-bearing government currency" [Bell July 1998, P 19] Wray writes, "To an uncertain but significant degree, the difference between spending and taxing over any particular period is "endogenously" determined by economic activity. By definition, the government's deficit (its spending less its tax receipts) must equal the nongovernment sectors' surplus (receipts from government spending less tax payments)." [Wray Nov. 2016, p.11] "In nominal terms, the equation is guaranteed and we can even assert that it is a position that is desired by the nongovernment sector (for otherwise, it would have spent more - reducing the government's deficit - or less, raising the deficit). [Wray Nov. 2016, p. 9] "When government sells bonds, banks buy them by offering reserves they hold at the central bank. The central bank debits the buying bank's reserve deposits and credits the bank's account with treasury securities. Rather than seeing this as borrowing by treasury, it is more akin to shifting deposits out of a checking account and into a saving account in order to earn more interest. And, indeed, treasury securities really are nothing more than a saving account at the Fed that pays more interest than do reserve deposits (bank "checking accounts") at the Fed." [Wray June 2014, p-3] "sovereign governments don't need to borrow their own currency in order to spend! They offer interest-paying treasury securities as an instrument on which banks, firms, households, and foreigners can earn interest. This is a policy choice, not a necessity" [Wray June 2014, p-4] "Usually the population also wants to save government monetary instruments for uses beyond taxes, so a government ought to run a deficit." [Tymoigne May 2017, p. 10] "When the nongovernment sector reduces its own spending - perhaps in an attempt to increase its saving - the government's deficit is likely to rise. Indeed, at least to some degree the government's deficit rises until the nongovernment sectors' desire to save has been satisfied." [Wray Nov. 2016, p.9] Bell also writes that "Banks, not wishing to hold an excessive amount of non-interestbearing government money, would be all-too-happy to exchange noninterest- earning reserves for interest-bearing Treasury bonds." [Bell July 1998, p. 22]

The MMT argues that the government will increase its deficit till saving appetite of the people is satisfied, because by selling government bonds government helps people to save. Because, people can save their money in banks and non-banking financial organizations, shares, debentures, bonds and fixed deposits in corporate sectors, real estate, gold, and invest in businesses, etc.

Again, Wray argues that "However, it is not necessary to remove all the issued currency through taxes. Some will continue to circulate to facilitate private transactions. Some can be accumulated as net saving. And some can be "redeemed" for bonds should the treasury decide to sell them." [Wray Nov. 2016, p. 9] 
However, these two statements of Wray are contradictory and unintelligible. If government creates money through only buying goods and services and the spending equals to the sum of proceeds from taxation and bond-sales, then no money will be left in the economy to make it possible that "Some [money] will continue to circulate to facilitate private transactions. Some [money] can be accumulated as net saving" as Wray (the MMT) claims it to be.

\section{(C) Bond-sales help money to be redeemed}

MMT argues that like tax, bonds are sold also to redeem the debt of the sovereign government, because when someone buys bonds paying money to the treasury, the money (IOU or debt of the government) is redeemed. Wray writes, "Indeed, currency that is redeemed for taxes or in receipt of bond sales is burned, not spent.” [Wray Nov. 2016, p. 9]

However, the MMT is wrong in thinking that returning of money through bond-sales to the treasury redeems the treasury's debt that the treasury has been created itself earlier when it has spent the money by purchasing goods and services. By selling bonds, Government becomes liable to repay the loan with accrued interest at the time the loan matures. Government is bound to make provisions to repay the debt (arise out of government-bonds) when the debt matures. Wray seems to be illogic. He did not justify that if government does not need to sale bonds for spending why then government sales bond when government is bound to repay the loan with accrued interest at the maturity of the bond.

Though Bell argues that "bonds need not be issued in order to allow the government to spend in excess of current taxation" [Bell July 1998, P 19] yet she accepts that bond sales help the government to spend in excess of taxation. She writes, "In the absence of bond sales, deficit spending would result in a net increase in aggregate bank reserves. Bonds, then, are used to coordinate deficit spending, draining what would otherwise become excess reserves. ... and allow the government to spend in excess of taxation" [Bell July 1998, P 19]

If government can create and spend as much money as it needs, then government should not deficit-spend and borrow through bond-sale or impose tax on its subjects. This is the contradiction or the limitation of the "tax-based chartalist" money or "Taxes Drive Money" theory.

\subsection{Theory of Functional Finance:}

The MMT adopted the theory of Functional Finance from the writings of Abba Lerner and Hyman P. Minsky. Minsky wrote "Stabilizing an Unstable Economy" in 1986. Abba Lerner wrote an essay entitled Functional Finance and the Federal Debt in 1943.

Wray, one of the leading economists of Modern Money Theory argues that "functional finance" approach can serve as the basis of fiscal policy formulation. He writes, "we will show how the "functional finance" approach of Abba Lerner follows directly from MMT. This leads to a discussion of monetary and fiscal policy - not only what policy can do but also what policy should do. Again, the discussion will be general because the most important goal of this Primer is to set out theory that can serve as the basis of policy formation." [Wray 2015, p. xi] 
According to Wray Minsky was the first to formulate "“functional finance" theory though he only once had used this term. "I do not recall Minsky ever discussing functional finance inside or outside the classroom. I've only found one use of it in his work - in a 1960 paper."' [Wray Jan. 2018, p. 6] Wray argues, a sovereign government "can adopt what Lerner called a "functional finance" approach to budgeting. What Lerner meant is that the policymaker's focus should be on the "functional" outcome of the policy rather than on the budgetary impact" [Wray Jan. 2018, p. 2] Bell writes, "In laying out the theory of Functional Finance in 1943, Lerner clearly believed that two economic ills - inflation and unemployment - had to be repressed if economic insecurity was to be eliminated." [Bell Nov. 1999, p. 13] "He [Lerner] formulated two principles of functional finance: government should spend more if there is unemployment, and government should supply more money (reserves) if interest rates are too high. ... his admonition [was] that finance should be "functional" (to achieve the public purpose) rather than "sound" (formulated to achieve "balance")" [Wray Jan.2018, p. 8]

Stephanie Bell explains Lerner's disposition on Functional Finance thus: “"'Lerner proposed his two "laws" of Functional Finance. The first law placed upon the government the responsibility for maintaining the total rate of spending on goods and services at the level necessary to purchase all of the output that it was possible to produce. In elucidating this law, Lerner explained that when spending was at the requisite level it would prevent both inflation and unemployment. In order to manipulate total spending, he suggested that the government increase its own expenditures or reduce taxes so that private spending would increase. Similarly, the government could cut its spending or raise taxes in order to reduce the total rate of spending: "By these means total spending can be kept at the required level, where it will be enough to buy the goods that can be produced by all who want to work, and yet not enough to bring inflation by demanding (at current prices) more than can be produced." (Lerner, 1943, p. 40)"' [Quoted in Stephanie Bell, Nov. 1999, p. 2]

"While Lerner did not initially believe that inflation would emerge before full employment had been reached, he later recognized that prices might begin to rise before all resources were fully employed. He noted that: $[\mathrm{A}] \mathrm{s}$ long as it is possible for the supply of goods to increase along with the increase in spending; there will be no (permanent) increase in prices. (Lerner, 1951, p. 8)" [Quoted in Bell Nov. 1999, p.3]

"Although prices might begin to rise prior to the attainment of full employment, they would not remain high and, thus, should not induce an abdication of the government's responsibilities with respect to the first law of Functional Finance.

The first law of Functional Finance is designed to eliminate a shortfall in total spending, while the second decrees the specific manner in which the deficiency is to be funded. Specifically, the second law calls for the sale of interest-bearing government debt only in the event that private spending would otherwise generate excessive aggregate demand. Under ordinary circumstances, Lerner argued, it is expected that capitalist economies will suffer from insufficient rather than excessive aggregate demand so that it would not be necessary to offer bonds in exchange for money as a means of tempering inflationary pressures. Instead, Lerner believed that bonds should be sold to the central bank or to private banks "on conditions which permit the banks to issue new credit money based on their additional holdings of government securities, [which] must be considered for our purposes as printing money" (Lerner, 1943, p. 41)." [Quoted in Bell, Nov. 1999, p. 3, Italics added] 
"Lerner advocated the printing of money to finance the spending necessary for the maintenance of full employment. Again, the idea is to sell bonds to banks (private banks or the central bank) as opposed to the non-bank public, so that funds which might otherwise be spent are not lured away (or "crowed out") by the government. Thus, while most economists would argue that the government should borrow from the public (i.e. sell bonds in exchange for existing money) in order to finance the excess of spending over taxation, Lerner believed that the government should do this "only if it is desirable that the public should have less money and more government bonds" (1943, p. 40)." [Quoted in Bell, Nov. 1999, p. 4]

"How might a country print money in conformity with Lerner's second law? ... In his [Lerner's] view, if private banks are capable of purchasing government debt by crediting a government account, this, too, should be considered printing money. Thus, when either the central bank or a private bank purchases newly-issued government debt by issuing credit or bank money, they are, in effect, printing money." [Bell, Nov. 1999, p. 4]

"if the central bank purchases a newly-issued security from the Treasury, it will do so by crediting the Treasury's account. ... Once the fiscal authority draws on this account in order to acquire goods and services, it can be said to have paid for its purchase by 'printing' money." [Bell, Nov. 1999, pp 4-5]

"Under Lerner's more general definition, however, whenever private or public banks, act "as agents for the government in issuing credit or bank money," they may be said to be printing money for the purposes of government finance (Lerner, 1943, p. 41). Not only can they print money on behalf of the government, but, as dictated by the second law of Functional Finance, Lerner argues that they should do so." [Stephanie Bell, Nov.1999, p. 6]

Wray writes, "Since many nations prohibit direct "money creation" by the government's treasury, the last option is possible only through complicity of the central bank-which buys the government's bonds, financing deficits by "printing money."' [Wray, Jan. 2010, pp. 47-48] Wray also argues that "In the case of a household, spending depends on income plus access to credit. However, the government's spending is said to be financed by tax revenue, "borrowing" (bond sales), and the printing of money. That final source of finance [the printing of money] is of course not available to the household," [Wray Jan. 2018, p. 3] However, Wray himself writes, "In the late 1960s the microeconomic household budget constraint was applied to government budgets (spending is "financed" by taxes, borrowing, or money printing). We've essentially been stuck with that view ever since. A sovereign's budget is "just like a household's," so it must adopt "sound finance."” [Wray March 2014, p.27] Hurford \& Kaboub quotes that Wray is of the opinion that, "With functional finance, sovereign governments do not finance projects with taxes or bonds, but rather finance projects through printing money (Wray 1998, p. 4)." [Hurford \& Kaboub, 2012, p. 23]

However, MMT gives contradictory statements regarding whether the government prints money (that is borrowing from the central bank) or directly credits banks' accounts. Wray writes, "the fear that government might "print money" if the supply of finances proves insufficient is exposed as unwarranted" [Wray, Oct. 2009, p. 10] as "Modern sovereign nation do not "print money" - they credit bank accounts." [Wray, Aug. 2003, p. 4] He argues, "It is commonly believed that if the government runs a deficit, it must "borrow" or "print money" to "finance" the deficit spending. This cannot apply to a sovereign nation. A sovereign nation spends by creating bank accounts, or by cutting treasury checks (which then leads to a reserve credit when the check is "deposited"). Whether or how much the government collects as taxes is 
not relevant to its spending. The implication of a budget deficit, as we saw ... is that bank reserves increase." [Wray, Aug. 2003, p. 3] However, Wray is wrong. Government cannot spend "by creating bank accounts, or by cutting treasury checks". "The Treasury must have a positive balance in its account at the Fed before it spends." [Tymoigne \& Wray, Nov. 2013, p. 28]

However, "In this example, narrow and base money do not each rise by an equivalent amount. In particular, there is no net increase in the quantity of base money as a consequence of the government's spending. This is why economists do not generally refer to this form of government finance as having resulted in the printing of money." [Bell, Nov. 1999, p. 6] Wray also accepts that the state cannot print money to increase its spending according to its needs. Wray writes, "The state no longer spent its IOUs, but rather ran its fiscal operations through its central bank, issuing bills, receiving credits to its account, spending central bank IOUs and receiving the same in tax payments." [Wray March 2014, P.27]

““"Lerner unabashedly denied any intelligent grounds for the adoption of so-called "sound" finance: "In brief, Functional Finance rejects completely the traditional doctrines of "sound finance" and the principle of trying to balance the budget over a solar year or any other arbitrary period. In their place it prescribes: first, the adjustment of total spending (by everybody in the economy, including the government) in order to eliminate both unemployment and inflation, using government spending when total spending is too low and taxation when total spending is too high; second, the adjustment of public holdings of money and of government bonds, by government borrowing or debt repayment, in order to achieve the rate of interest which results in the most desirable level of investment; and, third, the printing, hoarding or destruction of money as needed for carrying out the first two parts of the program.(Lerner 1943, p. 41)"' [Bell, Nov. 1999, p. 6]

However, Minsky and Lerner both have abandoned their theory of 'functional finance' as this would create big deficits and would be uncontrollable for the government. Wray himself writes, "Minsky appears to abandon functional finance and to adopt the deficit dove (or even deficit hawk) approach. [Deficit hawks want balanced budgets (or even budget surpluses); deficit doves accept budget deficits in recession but want these balanced against surpluses in the upswing (the terminology is credited to Stephanie Kelton). By contrast, deficit owls adopt the functional finance approach.] ... It appears that his views shifted and he took a harder line against big deficits." [Wray Jan. 2018, p. 5] Wray writes that Minsky was afraid of, "if government continues to run deficits even as it nears full employment, the danger of fueling inflation, as well as financial instability, rises. To preserve the purchasing power of bond holders, longer-term interest rates would need to rise. That could create a vicious cycle of bigger deficits, more inflation, and then higher interest rates to compensate for the inflation tax." [Wray Jan. 2018, p. 26]

Lerner in his 'Functional finance' approach suggested that government should increase its deficit and spending till full employment is reached. However, Government cannot increase spending causing increase in deficit persistently as it cannot increase tax infinitely to redeem its bonds and to pay interest on it, in future.

'Lerner [himself rightly] spelled out his opponents' fears regarding [government's]' excessive' indebtedness: "If the interest on the debt must be raised out of taxes . . . it will in time constitute an important fraction of the national income. The very high income tax necessary to collect this amount of money and pay it to the holders of government bonds will discourage risky private investment, by so 
reducing the net return on it that the investor is not compensated for the risk of losing his capital. This will make it necessary for the government to undertake still more deficit financing to keep up the level of income and employment. Still heavier taxation will then be necessary to pay the interest on the growing debt - until the burden of taxation is so crushing that private investment becomes unprofitable, and the private enterprise economy collapses. (Lerner 1943, p. 44)" [Bell, Nov. 1999, p. 8]

Minsky also abandoned his earlier stand on Functional Finance. Wray writes, "I will note that Lerner also abandoned his simpler functional finance approach in his later work-I think for much the same reason that Minsky had a decade earlier." [Wray Jan 2018, p. 6]

Both Minsky and Lerner realized that "a sovereign government that issues its own currency can never "run out of money"-it can never be forced into involuntary default and it can always make all payments as they come due" [Wray Jan. 2018, p. 2] is not true because government does not print or issue money and that government must repay the deficit using its tax-receipt. "He [Minsky] asserts that government must validate its debt with taxes, and goes on to repeat the common joke that: "Taxes are the price you pay for civilization."' [Wray Jan, 2018, p. 21] This means that Minsky no longer, in later years, believed that the sovereign can spend money as much as it needs because government's debts must be repaid with tax-receipts and tax-receipts cannot be increased without limit and increased expenditure leads to increase in interest rate and inflation.

Wray himself explained that because of the fear of increasing deficits that cause increase in interest rate and inflation, both Minsky and Lerner suggested increase in tax to offset the increase in deficits. Going further from his earlier stance, Lerner even argued later that it would be better to leave demand management to the monetary policy of the central bank than following a 'functional finance' approach in fiscal policy. Wray explains their later stands thus: "Lerner's rejection of his earlier views led him to argue that demand management should be left to monetary policy and placed under the control of the central bank. He argued that any increased government spending needs to be offset by a reduction of spending elsewhere-this could be reduction of some other government spending, but he advocated instead a tax increase that would reduce private spending. Ironically, Lerner replaced functional finance with a sound, balanced budget, finance approach-not because government would run out of money, but because he worried about the inflationary impact. He goes even further than the 'deficit dove' position, for he no longer suggests that the deficit must expand even in recession-on the argument that monetary policy alone could steer the economy.

This is somewhat in line with what Minsky was arguing - who also feared that fiscal policy had become too biased toward deficits and that debt could fuel inflation because the spending on transfers and interest payments are "inefficient"-although Minsky's views were better grounded in institutional reality, and he never adopted the Monetarist line that the Fed should be responsible for "demand management" through control of the money supply." [Wray Jan. 2018, pp. 32-33, Italics added] Bell writes, at first, "he [Lerner] opined that inflation would set in only after the system was pushed beyond full employment. Later, however, Lerner recognized that inflation would begin to set much sooner.” [Bell Nov. 1999, p. 13]

However, Wray's assertion, that state can print as much money as it needs to spend, is wrong. Wray himself writes, "The state no longer spent its IOUs, but rather ran its fiscal operations through its central 
bank, issuing bills, receiving credits to its account, spending central bank IOUs and receiving the same in tax payments." [Wray March 2014, p.27]

Though, in later years, both Minsky and Lerner abandoned their Functional Finance approach in favor of monetary policy under the control of the central bank, the MMT adopted the same Functional Finance approach to justify that government can print as much money as it needs to achieve Full Employment. Therefore, 'functional finance', as advocated by Wray, is not a practical way to solve the problem of financing government expenditure; it will increase both the government's burden of deficit budget and the inflationary interest rate. To make the 'functional finance' functional, MMT must find a solution to how the constraints of increased deficits like rising inflation and interest-rate can be controlled or eliminated.

\subsection{The Theory of Consolidation between the Central Bank and the Government:}

The MMT clams that it has contributed an original theory called 'Consolidation Theory' that explains that the Government and the $\mathrm{CB}$ is consolidated into one unit that is government sector. Other sector is the non-government sector. By 'non-government sector' they only mean the commercial banks. They claim that one should not look into what is going on between the $\mathrm{CB}$ and the Government relating to government's income and expenditure and into who is issuing sovereign currency the government or the CB.

"Perhaps the most important original contribution of MMT has been the detailed study of the coordination of operations between the treasury and the central bank. Central bank is the treasury's bank, making and receiving payment on behalf of the treasury. The procedures involved can obscure how the government "really spends". While it was obvious two hundred years ago that the national treasury spent by issuing currency, and taxed by receiving its own currency in payment, that is no longer so obvious because the central bank stands between the treasury and recipients of government spending as well as between treasury and taxpayers making payments to government." [Wray June 2014, p. 2] Thus the central bank helps the government to execute its fiscal policies. The government also helps the central bank in its monetary policy operations like targeting overnight rates of interest. Wray explains why the MMT favours the consolidation between the central bank and the Treasury. He writes, -"There are two real world complications that require some comment. First, most payments in modern economies do not involve use of a government-issued (state, "fiat") currency; indeed, even taxes are almost exclusively paid using (private) bank money. Second, government money is not emitted into the economy solely through treasury purchases. In fact, the central bank supplies most of our currency (paper notes), and it is the proximate supplier of almost all of the bank reserves that are from the perspective of the nonbanking public perfect substitutes for treasury liabilities. Obviously if we simply consolidate the central bank and the treasury, calling the conglomerate "the state", we eliminate many complications." [Wray July 2005, p. 18] He writes, -"When talking about the net impact of fiscal operations on the nongovernment sectors we sometimes consolidate the treasury and central bank-since the internal operations have no impact whatsoever on any entity outside government." [Wray 2019 Oct 14, p.5] Explaining how the central bank and the Treasury halp one another thus: -"To put it as simply as possible, current procedures ensure the Treasury has credits to its account at the Fed that can be debited when the Fed credits reserve accounts of the private banks of the recipients of Treasury spending. This is little more than internal record keeping between the Treasury and the Fed. If it is projected that the Treasury's credits will fall short of debits, 
Treasury will sell bonds to dealer banks that stand ready to place bids. The Fed, in turn will supply reserves as necessary to ensure bonds sold in the new issue market do not place temporary pressure on overnight rates. As bonds are sold, Treasury's deposit at the Fed is credited. Treasury spending reverses this process as its deposit account is debited and private bank reserves are credited, with the Fed then removing reserves from the banking system as necessary to remove pressure on rates" -[Wray 2019 Oct, p.19]

\section{The Government helps the Central Bank to keep Fed Fund Rates on Target:}

"The old monetarist preference was instead for a quantitative target (reserves) that would allow the central bank to control money growth. That was then supposed to allow the central bank to keep inflation low ... Modern central banks have dropped monetary (quantitative) targets in favor of interest rate (price) targets - both because they are easier to hit and because the current thinking is that they are more reliably linked to the goals." [Wray March 2014, p. 12] "In practice there are many interest rates, so central banks typically target the overnight interbank rate (fed funds rate in the US) with a view to affecting other market rates." [Wray March 2014, p.11]

"There [is] a distinction among tools, targets, and goals [of the central bank]. Goals are usually defined in terms of unemployment, inflation, and growth ... the central bank targets an inflation rate that serves as a measure of monetary policy success; employment and output growth are then expected by-products of hitting the inflation target." [Wray March 2014, p.11]

Wray writes, "MMT recognizes that bond sales by sovereign government are really part of monetary policy operations. While this gets a bit technical, the operational purpose of such bond sales is to help the central bank hit its overnight interest rate target (called the fed funds rate in the US). Sales of treasury bonds reduce bank reserves and are used to remove excess reserves that would place downward pressure on overnight rates. Purchases of bonds (called an open market purchase) by the Fed add reserves to the banking system, prevent overnight rates from rising. Hence, the Fed and the Treasury cooperate using bond sales/bond purchases to enable the Fed to keep the fed funds rate on target." [Wray June 2014, p. 4] Besides, "To avoid wide fluctuations of reserves and to deal with net reserve accumulation [in banking sector] due to government spending in excess of tax payments as well, the central bank and treasury coordinate bond sales to drain excess reserves. For this reason, MMT sees bond sales as part of monetary policy operations - whether undertaken by the central bank or by the treasury." [Wray 2019 Sept. p. 6]

In defense of the consolidation theory, Bell writes, "Note that the government can deficit spend without taxing or selling bonds first but that if government spending is greater than taxation, the banking system will be left with excess reserves. The Treasury, therefore, prefers to use bonds to coordinate its deficit spending, selling them to Special Depositories (and allowing T\&L credit) before spending from its accounts at Reserve banks. The bonds, then, allow the government to defend (ex ante) the fed funds rate." [Bell July 1998, p. 17]

"When the Treasury does spend these proceeds [from sales of Treasury bonds], the deposits and reserves of banks are restored. At this point, the Fed will need to reverse its previous operation: banks will now have excess reserves that can be drained either through an open market sale of Treasuries by the Fed (that is, the Fed sells the Treasuries it just bought) or the Fed and banks wind down discount window loans. [Wray March 2014, p.17] 
"Likewise, the instrument typically used in monetary policy to maintain positive interest rates is treasury debt, not central bank debt.” [Wray March 2014, p.20]

However, it is not correct that buying and selling of government bonds help the central bank to maintain a positive interest rate target. On the contrary, central bank can increase or decrease the interest rate payable on the government bond. Wray himself argues, "But it is simply false reasoning that leads to the belief that the size of a sovereign government deficit affects the interest rate paid on securities. No matter how large the budget deficit, the central bank can set the overnight rate where it likes, and can hit the target." [Wray, August 2007, p 23] Wray himself writes, "It is true that the central bank can choose to keep the interest rate paid by treasury on its debt higher, or lower, which impacts overall government spending (since interest is a cost covered by spending)." [Wray March 2014, p.20] According to him, "the Fed has a great deal of discretion over its setting of the interest rate target. In practice, almost any rate target could be justified as consistent with the goals." [Wray March 2014, p. 12] Wray also accepts that "bonds are not needed ... to help the central bank to hit [interest] rate targets." [Wray 2015, p 4] Wray accepts that not the Government but "the central bank sets the overnight interest rate target - it adds/drains reserves as needed to hit its target rate". [Wray, Oct. 2009, p. 5]

The government also can set interest rates on bonds independently of the central bank. Wray himself argues that "the Treasury can offer to sell securities that pay a few basis points above zero and it will find willing buyers because such securities offer a better return than the alternative (zero)." [Wray, August 2007, p 23] He writes, "Note also that the interest rate paid on treasury securities is not subject to normal 'market forces'.... When the overnight rate is zero, the Treasury can offer to sell securities that pay a few basis points than the alternative (zero). A sovereign government with a floating currency can issue securities at any rate desired - a few basis points above the overnight interest rate target." [Wray, 2008, p 104]

Again, maintaining a positive interest rate is not the end in itself. The aim of maintaining positive interest rate is to keep inflation in check and to help growth in investment, production and distribution. There are many monetary policies, other than purchasing and buying government bonds, that the central bank may use to keep a positive interest rate. Cash Reserve Ratio, Standard Liquidity Ratio, repos, reverse repos, overnight interest rate etc. can be used to reverse or to minimize the effects of either purchasing or selling of government bonds. Wray is fully aware of it. He writes, "Note the Fed for some time has used repos and reverse-repos rather than outright sales and purchases-which ensures actions can be quickly reversed to minimize the Treasury's operational impacts on bank reserves.” [Wray March 2014, p.17]

\section{The Central Bank helps the Government to pursue its Fiscal Policy by Providing Adequate Reserve to the Treasury:}

Wray argues that the central bank provides adequate reserves to the commercial banks so that they can buy government bonds selling of which is a necessity to keep on government spending. Wray writes, "Since central bank purchases of securities supply the reserves needed by banks to buy government debt, a virtuous circle is created, so that the treasury faces no financing constraint. ... the central banks are essentially "printing money" to keep sovereign-government borrowing costs low." [Wray March 2014, p.1] Therefore, "We will argue here that the Fed is independent only in a very narrow sense." [Wray March 2014, P.4] 
"The Treasury and the central bank also work closely in the Treasury's management of its substantial cash payments and withdrawals of Treasury Tax and Loan account balances deposited in commercial banks, since these cash flows affect bank reserves." [Wray March 2014, p.14] "In practice, the Treasury attempts to maintain a constant (small) positive account balance at the Fed, which ensures that fiscal operations do not affect private bank and reserve balances." [Wray March 2014, P.15] "we presume that the Fed is to cooperate with the Treasury so that the fiscal operations proceed smoothly. ... How do the Treasury and Fed ensure that budget deficits over a time period (spending greater than receipts) do not affect bank reserves and deposits? The key is "debt management": new issues of Treasuries by the Treasury and/or open market sales by the Fed. ... That can be accomplished by selling new Treasuries to banks, which would credit the Treasury's deposits. However, when the Treasury shifts deposits, the Fed needs to debit bank reserves. Since in normal times banks do not operate with excess reserves ... The Fed can either lend the reserves or it can buy Treasuries in open market operations ... it really cannot refuse to supply the reserves [to the banks]. [If the Fed does not supply the banks with reserve and the banks do not have sufficient reserve to buy Treasuries], it would cause the fed funds rate to rise above target. If a central bank targets overnight rates, it must accommodate demand for reserves. In other words, the central bank's "independent" interest rate-setting conflicts with its "independence" from fiscal operations, in the sense that it must provide the reserves banks will need when the Treasury moves the proceeds from a bond sale to its account at the Fed in order to make payments." [Wray March 2014, p.16] [Again], "The Fed's choice is not to refuse to "cut checks" so that the Treasury can spend funds allocated by Congress, but rather to tighten [monetary] policy if it believes fiscal policy is too expansive." [Wray March 2014, p.16] Thus, "the Treasury and the Fed cooperate to bring about a fairly high degree of harmony in managing the Treasury's balances at Reserve banks" [Bell July 1998, p. 14]

\section{The Fed is not Independent from the Government:}

"The problem is that most people think Fed independence is natural, desirable, and immutable. But in reality, the Fed is a branch of government and a creature of Congress" [Wray March 2014, p.26] "This paper argues that the Fed is not, and should not be, independent, at least in the sense in which that term is normally used. [because]," [Wray March 2014, p.1] "In the US, the Fed is a "creature of Congress," established by the Federal Reserve Act of 1913 ... Elected officials play a role in selecting top Fed officials. And while the Fed is nominally owned by share-holding banks, and while the Fed's budget is separate, profits above $6 \%$ on equity are returned to Treasury. ... Further, as we will see, the Fed's operations are necessarily closely coordinated with the Treasury's; the Fed, after all, functions as the Treasury's bank." [Wray March 2014, p.6] "it [the central bank] is subject to the will of Congress. Further, the Fed cannot really be independent from the Treasury, because the Fed is the federal government's bank, with almost all payments made by and to the government running through the Fed. As such, there is no "operational independence" that would allow the Fed to refuse to allow the Treasury to spend appropriated funds. [Wray March 2014, p.1]

"We conclude this section with the finding that the legislated "operational independence" of the central bank is limited in practice because the actual procedures adopted ensure the central bank cooperates with the treasury as it implements fiscal policy." [Wray March 2014, p.20] "Chairman Ben Bernanke has said that "of course we'll do whatever Congress tells us to do": if the Congress is not satisfied with the Fed's actions, the Congress can always tell the Fed to behave differently." [Wray March 2014, p.5] 
"However, the claims for Fed independence are overstated. First, for the reasons discussed above, the Fed must coordinate with Treasury operations to ensure it can hit overnight rate targets. Second, the Fed is a "creature of Congress," created by public law that has been amended several times." [Wray March 2014, p. 27] "In conclusion, we see that there is no place in the current operating procedures for the Fed to prevent the Treasury from spending budgeted amounts." [Wray March 2014, p.22]

However, the fact is that the Central Bank is not a government organ but an independent institution. Though in the past, government used to buy government bonds directly from the government but, now-adays, central bank does not buy government bonds directly. [Wray argues that] MacLaury summarizes the evolution of Fed and Treasury sharing of responsibilities as follows: [Until 1951]"Because the central bank supported the market for government securities, it was forced to purchase amounts of securities necessary to maintain low interest rates and the par value of securities. Thus, as the Treasury issued additional debt, the central bank was forced to acquire part of that debt. This process resulted in direct addition to bank reserves. Following the 1951 accord between the Treasury and the Federal Reserve System, the central bank was no longer required to support the securities market at any particular level. In effect, the accord established that the central bank would act independently and exercise its own judgment as to the most appropriate monetary policy." [Wray March 2014, p.13]

Wray is fully aware that, "the central bank of a developed nation is often prohibited from directly financing government budget deficits - as in the US where the FRA mandated a separation of fiscal finances from central bank operations. This is a deviation from the traditional role of the first central banks, which was quite explicitly created to provide state finance.” [Wray March 2014, p.14]

However, "Fed's independence" is not "overstated", because "the Fed's monetary policy is not subject to audit by the Government Accountability Office (GAO) — and courts have refused to hear suits that accuse the Fed of policy mistakes." [Wray March 2014, p.8] Therefore, issuing of money by the central bank cannot be treated as government money because government just depends on the tax-receipts and on proceeds from bond-sales for its spending. And the Central Bank does not buy government bonds directly from the government.

Wray himself wrote that the central bank and the government are separate institutions. He writes, "Now, we recognize that in developed countries today there is a division of responsibilities between the Treasury and the Central Bank and that the Central Bank is in many nations nominally independent of the State.... with the case of the US - which separates the Fed and Treasury" [Fullwiler, Kelton and Wary, Jan 2012, p.3] Wray is aware that, the Federal Reserve Act of 1913 legislated for independence of the Fed from the Treasury.

Wray also knows that in reality there is no consolidation between the government and the central bank. Wray only wishes, "if we simply consolidate the central bank and the treasury, calling the conglomerate "the state", we eliminate many complications. When one uses a bank liability to pay "the state", it is really the bank that provides the payment services, delivering the state's fiat money, resulting in a debit of the bank's reserves. When the state spends, it provides a check that will be deposited in a bank, leading to a reserve credit on the books of the bank. ... only payments to the treasury or cash withdrawals from banks cause a reduction of banking system reserves, while payments by the treasury result in reserve credits." [Tymoigne, Eric \& L. Randall Wray July 2005, p.17] This statement of Wray clearly proves that what the MMT claims as 'consolidation' is not a reality but merely fantasy. The MMT only hopes, what 
the monetary and the fiscal situation would be if a consolidation between the central bank and the government could be achieved.

From the above discussion, it becomes clear that though central bank and government co-operate in their monetary and fiscal policies, yet they cannot be consolidated in the same bracket of government sector. The central bank is free from any government control in its monetary policy formulations and government is free from central bank's control in its fiscal policy formulations. The original contribution of MMT in assuming a "consolidation" between the government and the central bank does not help any way in avoiding "deficit ceiling" constraints in pursuing fiscal and monetary policies. The consolidation theory only blurs our vision in identifying and understanding what really monetary and fiscal policies respectively of the central bank and the government are.

\subsection{Theory of the Government as the Employer of Last Resort:}

The MMT's claim that if the government as the Employer of Last Resort (ELR) spends sufficiently to achieve Full Employment (FE) then budget deficit and inflation will not increase excessively, is wrong.

Pavlina R. Tcherneva argues that "The private sector is unable to produce and maintain tight full employment over a long run." [Tcherneva April 2018, p. 2] Therefore, government should become the Employer of Last Resort (ELR). The system through which the government will employ all the unemployed will be ELR Program. This is also called as "the Job Guarantee (JG)." "Full employment is defined as a situation where any person of legal working age who wants to work is able to obtain employment at a living wage and decent working conditions." [Tcherneva April 2018, p. 2] Wray claims that "I summarize an employment program that will guarantee true, full employment (or zero unemployment) for all. ... Further, the full employment policy would help to reduce economic fluctuation (the "business cycle") through a powerful built-in automatic stabilizer." [Wray June 1998, p.540]

The MMT argues that government can afford spending to achieve employment for all the unemployed. Wray asserts that "It will be clear that I do not accept such a view-to the extent that sovereign governments operate under financial constraints, these are self-imposed and mostly result from political considerations. Sovereign governments can always financially afford to provide jobs to unemployed workers." [Wray Aug. 2007, p. 21] He suggests that "The ELR program will be financed in exactly the same manner that military spending or Social Security spending or highway spending is accomplishedby crediting bank accounts. If there are limits to government spending (and I [Wray] agree that there are, however, they have nothing to do with financial constraints), they do not result from the method used to finance such spending." [Wray Aug. 2007, p. 23] He wants that the expenses of the government will be funded by the sin-tax paid by the rich, as the rich have accumulated wealth through the sinful way. He is against taxing the poor. He writes, "It is fitting that those who already enjoy all the benefits of life at the top ought to suffer more when they are sinful. Don't tax the sin of the worker who enjoys the occasional six-pack of brew. Go after the real sinners - those with the wherewithal to engage in truly anti-social sinning-speculative and consumption excess." [Wray, Nov. 2012, p. 18] It is clear that he is not consistent in his arguments. Once, he says that as a sovereign issuer of money the government can spend whatever it needs to spend. Again, he opines that the rich should pay sin-tax to fund the government expenses. . 
Besides, Wray's concern for giving employment to the unemployed is half-hearted and halting, it is not "True Full Employment". He suggests minimum wage for the ELR workers and that too will be fixed. According to Hurford and Kaboub, Wray's view is that "The ELR wage can be pegged to the current minimum wage", [Hurford and Kaboub, 2012, p. 22] and that, "in the ELR program, the wage is fixed but the quantity floats". [Wray, Aug. 2007, p. 18] and "This is why "it is probably less disruptive to initially put the ELR wage at the minimum wage". [Wray, Aug. 2007, p. 18] Other MMT economists even want to levy tax on those who would be employed at the fixed minimum wage. "An income tax of $15 \%$ on this wage would recover $\$ 2,262$ per worker-year, or $\$ 52$ billion over a program that hires all 23 million underemployed." [Hurford and Kaboub, 2012, p. 23] Therefore, the intention of the MMT is not to employ the unemployed with the full remuneration and parks that the government employees enjoy.

However, Wray did neither prescribe any alternative to "accepted economic theory" nor any suggestion alternative to present economic practices that can solve the present impasse of fiscal deficits so that the government may be able to finance ELR program. Wray only argues that the "debt-ceiling" is a political decision and not an economic one. He argues that even after 50 generations people may opt for more increase in government deficit or in debt to continue the ELR program. Thus, he became oblivious of the fact that the government cannot increase its debt because government cannot increase tax unlimited to repay the debt. Wray knows it well. That is why he argues that government may increase its deficit to any amount that is sufficient to meet full employment policy. However, he did not suggest any means how the government will be able to repay its debt. He only argues, "ELR, by design, ensures that the deficit will rise only to the point that all involuntary employment is eliminated: once there are no workers willing to accept ELR work, the deficit will not be increased further." [Wray June 1998, p. 541]

In his article "zero Unemployment and stable prices" [Wray June 1998, p. 539], Wray claims that ELR program will not induce price-inflation because "With ELR in place, however, labor is paid for working, which can lead to production of publicly supplied goods and services". What is termed by Wray as "publicly supplied goods and services" is not at all "public", because the works of the ELR workers will only "reduce private sector costs (for example, by reducing crime), and can increase the education and skills of the ELR workers (compared with education and skill level of the unemployed)." [Wray June 1998, p. 543] It is also not at all "employment"; ELR workers does not work for the employer but only for themselves. Wray writes, "In contrast to the current "unemployment compensation" system ... ELR can require that the six weeks will be spent doing specific search activities (reporting to an office to make phone calls, prepare a 'c v', attend job interviews, obtain job search training, and so on)". [Wray Nov 1997, p. 8] He writes, "we might decide that single mothers with young children should be able to choose to stay home; their "job" would be to care for their children. More generally, it might make sense to train (or retrain) some workers rather than to put them into unskilled jobs; their ELR "job" would be to attend school or an apprenticeship program." [Wray Nov. 1997, p.51] "Other projects include health promotion programs, which offer basic education on sanitary issues-for example, how to boil water, handle food, and avoid dysentery and other infections. Others deal with mending old clothes that have been donated to poor communities." [Tcherneva \&Wray May 2005, pp 28-29] However, such "publicly supplied goods and services" of the ELR workers do not create any marketable goods and services. Therefore, the ELR workers will spend their earning in buying goods and services that are produced by the private sector and the government and not by themselves. This will add extra demand to the already existing demand for marketable commodities and thus will induce prices to hike. 
The workers of the ELR Program will not get any permanent job. Wray writes, "There is no timerelated underemployment in the JG [ELR] because workers would be able to choose any fraction of working hours from full-time down to 1 hour per week according to their preferences." [Wray Jan 2005, p.8 \& Wray May 2004, p 9] "The program could provide for part-time and seasonal work, as well as for other flexible working conditions as desired by the workers." [Wray May 2005, p. 13]

However, Wray discarded the policy of government spending for employment generation as advocated by Keynes. He argues, "This stands in stark contrast with "Keynesian" demand management policies that were designed to "prime the pump" with government spending that would increase private demand sufficiently to lower unemployment to the "full employment" level. The danger was that this would lead to such "tight" labor market that inflation would be generated long before reaching full employment." [Wray June 1998, p. 543] The difference between the Keynes' prescription and Wray's suggestion is Keynes like Wary did not suggest that all unemployed must be employed even if deficit rises above government's ability to repay its debt (deficit ceiling) and that like Wray Keynes did not suggest that all unemployed will be paid a fixed minimum amount of wages irrespective of their level of efficiency and experience. "Lerner opposed pump-priming for its formulation often implicitly called for the balancing of the government's budget as an objective goal: a practice which is fundamentally at odds with the theory of Functional Finance." [Bell Nov. 1999, p. 2] MMT is heavily indebted to Lerner's two laws of "Functional Finance" that he advocated in 1943 in his essay "Functional Finance and the Federal Debt". In his first law "What Lerner advocated, in this essay, was the maintenance of true full employment" while the second law "decrees the specific manner in which the deficiency [the gap between income from taxation and actual budgetary expenses] is to be funded. Specifically, the second law calls for the sale of interest bearing government bonds" [Bell Nov. 1999, pp. 2-3] However, in both the cases (Wray's suggestion of ELR Program and Keynes' prescription what Wray calls "prime the pump") of government spending for employment-creation, price positively rises. Wray himself accepts that ELR program also leads to price-rise. He made a contradictory statement, "In conclusion, ELR is not likely to induce inflation - much less to cause accelerating inflation - even if it does cause prices to rise when implemented and each time the ELR wages is raised." [Wray June 1998, p. 544]

Wray asserts that "Sovereign governments can always financially afford to provide jobs to unemployed workers." However, Wray himself argues that spending for achieving full employment will increase government deficit/ debt. Wray writes, "We would restate it as follows: tax rates should be set so that the government's budgetary outcome (whether in deficit, balanced, or in surplus) is consistent with full employment. A country like the US (with a current account deficit at full employment) will probably have a budget deficit at full employment (equal to the sum of the current account deficit and the domestic private sector surplus). A country like Japan (with a current account surplus at full employment) will have a relatively smaller budget deficit at full employment (equal to the domestic private sector surplus less the current account surplus).” [15 May 2014, p. 4]

Wray himself accepts that "Paradoxically, neither accepted economic theory nor practical experience indicates that high or low full employment is even possible with stable prices." [Wray, Nov 1997, Abstract] However, Wray asserts that "Even if the ELR did not increase price stability, we would prefer continued instability in prices - such as that experienced since WWII - over wage and price controls." [Wray, Randall, Nov 1997, p 27] 
The ELR program will burden the government with excessive deficit. The MMT's assertion that "It is necessary to admit that our proposed policy could lead to an increase of government spending; indeed a persistent government deficit could result ... they do not "burden" future generations, and they cannot lead to "financial ruin" of the government. [Wray, Nov 1997, p 3] and "the design of the ELR guarantees that the deficit will not become "excessive", that is, it will not increase aggregate demand beyond the full employment level." [Wray, August 2007, p 16] is unfounded.

However, the reality is that a "big deficits" and "a persistent government deficit" that could result" will surely create unbearable "burden" for future generations" and will cause "financial ruin" of the government and of the economy. Lerner rejected deficit spending on the ground that "If the interest on the debt must be raised out of taxes. ... it will in time constitute an important fraction of the national income. ... Still heavier taxation will then be necessary to pay the interest on the growing debt - until the burden of taxation is so crushing that private investment becomes unprofitable, and the private enterprise economy collapses. (Lerner 1943, p. 44)" [Bell, Nov. 1999, p. 8]

Wray's claim of how money will be available for achieving full employment is not realistic. Wray argues "When government issues HPM to buy something, it is 'liable' only to accept that same HPM in epicentric (i.e., tax) payments to the state" [Wray, Dec. 2001, p.12] and "If however the state were to limit its spending below the level that would provide subjects/ citizens with the means of tax payment desired, there could a 'queue' of those willing to 'work' to supply goods and services to government and/ or markets, but unable to find a demand for their goods and services. They are effectively 'unemployed' because of insufficient government spending - the source of means of tax payments." [Wray, Dec. 2001, pp 11-12]

However, Wray contradicts himself when he places another argument that, "In order for nongovernment entities to net hoard HPM, government must provide more HPM than it drains through tax payment - in other words, government must run deficit. ... what if government's provision of HPM left an unsatisfied demand for HPM for hoarding? The government would see queues of those offering goods and services for sale for HPM. As we discussed above, this could be defined as unemployment, as there would be people willing to work to supply goods and services to obtain HPM.” [Wray, Dec. 2001, pp 14-15]

Therefore, MMT's policy proposal for "True Full Employment" or for "Job Guarantee" through "Employer of Last Resort Program" is also contradictory and confusing and unrealistic. Without a solution to the constraints for deficit financing with an alternative provision for government spending, the ELR program cannot be achieved successfully.

\subsection{Sectoral Financial Balance (SFB) Approach:}

The approach of "“sectoral financial balances", an analytical framework learned from the work of the late Wynne Godley. The essential idea is that since income has to equal expenditure for the economy, as a whole, (which is the same things as saying that saving equals investment) so the sums of the difference between income and expenditures of each of the sectors of the economy must also be zero. These differences can also be described as "financial balances". Thus, if a sector is spending less than its income it must be accumulating (net) claims on other sectors. The crucial point is that, since sectoral balances must sum to zero, a rise in the deficit of one sector must be matched by an offsetting change in the others. 
It follows that if the fiscal deficit is increasing, the sum of the surpluses of the other sectors of the economy must be increasing in a precisely offsetting manner." [Martin wolf 2012 July]

"The SFB approach, known also as "New Cambridge", is an ex post accounting identity derived by rearranging the components of aggregate demand and typically presented as a three-sector model comprising the private, public and foreign sectors. It is an important identity insofar as it links aggregate demand with changes in sectoral net financial asset positions." [Fiebiger 2013, p.59]

Sectoral analysis is based on the insight that when the government sector has a budget deficit, the nongovernment sectors (private domestic sector and foreign sector) together must have a surplus, and viceversa. In other words, if the government sector is borrowing, the other sectors taken together must be lending. The balances represent an accounting identity resulting from rearranging the components of aggregate demand, showing how the flow of funds affects the financial balances of the three sectors. [Wiki, Sectoral Balances]

Wynne Godley writes, "It is well known to students of the National Accounts that the surplus of private disposable income over expenditure is equal to the government balance (written as a deficit) plus the current balance of payments (written as a surplus). While these balances are related to one another by a system of accounting identities, each has, to some extent, a life of its own that is reconciled with the other two via the aggregate income flow." [Wynne Godley March 2003, p. 2]

Godley wrote in 2005 that: "[T]he deficit of the general government (federal, state, and local) is everywhere and always equal (by definition) to the current account deficit plus the private sector balance (the excess of private saving over investment)." [Wynne Godley June 2005] We can express the formula, of sectoral balance identity as: (Savings - Investment $)+($ Imports - Exports $)+($ Tax Revenues - Outlays $)=$ $0 ;$ or $(\mathrm{S}-\mathrm{I})+(\mathrm{M}-\mathrm{X})+(\mathrm{T}-\mathrm{G})=0$.

According to this definition, savings (surplus) of the private sector must be equal to the aggregate deficit of the other two sectors (government and foreign) taken together. Therefore, "private net saving is always identically equal to the government's budget deficit plus the current account surplus." [Wynne Godley Nov. 2007, p. 2]

As according to this sectoral financial balance approach, government spending is the only source of the income of the private sector, so, government should deficit spend whenever the private sector needs more income. Just before the great recession of 2008, when the private sector became indebted too much, Wynne suggested, "We conclude that at some stage there will have to be a relaxation of fiscal policy large enough to add perhaps 2 percent of GDP to the budget deficit." [Wynne Godley Nov. 2007, p. 8]

However, Wynne Godley also suggested that government should not increase its deficit spending to help private sector continue to increase its borrowing. He writes, "But private debt and borrowing cannot continue to provide the motor for expansion for more than a couple of years, particularly if interest rates go on rising. The growth in private debt must eventually slow down, causing net lending to fall and thus threatening recession, exactly as happened in 2000. But there can be no remedy this time in the shape of a fiscal expansion.” [Wynne Godley April 2005, p. 4]

He writes: "[In the baseline scenario,] a government deficit ratio equal to 9 percent of GDP, combined with interest rates in excess of 5 percent, would send the internal and the external debts hurtling towards 100 percent of GDP, with more to come after that. And, if there is anyone who considers a 9- percent budget deficit to be tolerable, what about 15 percent, or 30 percent? It has to stop somewhere. The longer the debt and deficit ratios go on rising, the larger and more painful the adjustment will be when the tide 
eventually turns.” [Godley, W., Izurieta, A., and Zezza, G., August 2004, p. 5; quoted in Brett Fiebiger 2013, pp. 66-67]

In 2007, Wynne Godley observed that "under the "credit crunch" assumption (Figure 8), the fall in private net expenditure is so large that the economy will enter a recession next year." [Wynne Godley 2007 Nov, p. 7] In this background of credit crunch, Wynne Godley is also of the opinion that fiscal policy is not capable of resolving the problem associated with the expansionary deficit spending. He writes, "The budget deficits imply that the public debt relative to GDP would rise permanently to about 80 percent, while GDP would remain below trend, with unemployment above 6 percent. Fiscal policy alone cannot, therefore, resolve the current crisis." [Godley, W., Papadimitriou, D., and Zezza, G, December 2008, p. 4; quoted in Brett Fiebiger 2013, p. 67]

Economists of Modern Money Theory used this approach of sectoral financial balance to illustrate the relationship between government budget deficits and private saving (holding of government bonds). L. Randall Wray writes, "Wynne Godley taught us about balances - the sectoral balances." [Wray Jan 2012, p.15] Wray explains, -"One of the concepts that Modern Money Theory economists use to elucidate the impact of budget deficits on the economy is the sectoral balance identity developed by Wynne Godley (1996). At the level of the economy as a whole, aggregate spending is identically equal to aggregate income - every dollar spent is received as income. It is useful to divide the economy into three sectors: government (national, state, and local), domestic private (households and firms), and foreign (rest of the world). If one sector spends more than its income (deficit), at least one other must spend less than its income (surplus) to maintain the aggregate identity that total spending equals total income. The balances (income minus expenditure) of the three sectors have to add up to zero since we are adding up all the income in the economy and subtracting all the spending, which are equal by identity. We can then write the aggregate identity as: government balance + domestic private balance + foreign balance $=0$." [Wray 20 Nov 2019, p. 9]

"[T] he sectoral balances show that, as a matter of national accounting, the national government deficit (surplus) equals the non-government surplus (deficit). Contrary to neo-liberal rhetoric, the systematic pursuit of government budget surpluses is necessarily manifested as systematic declines in nongovernment savings. Budget surpluses necessarily decrease net non-government savings, and with an external deficit, result in increasing private domestic sector debt levels." [Mitchell April 2013, p.13]

Wray also writes, "Following Wynne Godley (1996) we can instead use a stock-flow consistent balances approach: a sector's spending flow must equal its income flow plus changes to its financial balance. A sector can spend more than its income, but this implies a deduction from its net financial assets. At the same time, the deficit spending of one sector implies that at least one other sector must be spending less than its income, accumulating net financial assets." [Wray Oct 2009, p.6] "[T] he conclusion from close analysis is that government deficits do lead to net credits to reserves and if excess reserves are created they are drained through bond sales." [Wray Oct 2009, p.8] "[G]overnment deficits mean net credits to banking system reserves and also to nongovernment deposits at banks." [Wray Oct 2009, p.6]

Wray explains how the balance between government sector and nongovernment sector works. He writes, "[T] he financial processes are not hard to understand. Government spends (purchasing goods and services or making "transfer" payments) by crediting the bank accounts of recipients; this also leads to a credit to their bank's reserves at the central bank. The government taxes by debiting taxpayer accounts (and the central bank debits reserves of their banks). Deficits over a period (say, a year) mean that more bank accounts have been credited than debited. The nongovernment sector realizes its surplus initially in the form of these net debits to bank accounts. All of this analysis is reversed in the case of a government surplus: the government surplus means the nongovernment sector runs a deficit, with net debits of bank accounts (and of reserves).” [Wray Oct 2009, p.7] 
"In the three-sector model, the domestic private sector balance plus the government balance equals the external sector balance." [Wray Oct 2009, p.11] "For example, in a two-sector model, the government's deficit spending (and thus its net debt issue) is identical to the nongovernment sector's budget surplus (and thus its net accumulation of financial assets, which are claims on the government sector)." [Wray Oct 2009, p.6] "At the aggregate level, a government deficit is offset by (and identically equal to) a nongovernment surplus; and a government surplus is offset by a nongovernment deficit. The government's budget can "balance" (spending equals taxes) only if the nongovernment sector's budget "balances" (spending equals income)." [Wray Nov. 20012, p.19]

"One of the concepts that Modern Money Theory economists use to elucidate the impact of budget deficits on the economy is the sectoral balance identity developed by Wynne Godley (1996). At the level of the economy as a whole, aggregate spending is identically equal to aggregate income - every dollar spent is received as income." [Wray Nov 2019, p.9] "We can then write the aggregate identity as: government balance + domestic private balance + foreign balance $=0$ ". [Wray Nov 2019, p.9] "[W] prefer to write equation ... as the following: ... Private Sector Surplus or Net Saving = Government Deficit + Current Account Balance." [Fullwiler 2009, p.3] "[T] he sector financial balances model of aggregate demand (hereafter, SFB model) is based upon the following standard macroeconomic accounting identity from any macroeconomics textbook: (1) Private Saving - Investment $=($ Government Spending - Taxation) + (Exports - Imports)" [Fullwiler 2009, p.2]

However, though the MMT economists claim that the Sectoral Financial Balance approach presents the deficit-surplus relation among the three sectors of global economy, yet, it describes only the distribution of budgetary income and expenditure of a government. They claim that sum of the balances of each sector equals to zero. But, in reality, the balances of foreign and private sectors are not shown in this Sectoral Financial Balance approach. They claim that the current account balance (surplus/deficit) of a government is the net balance (deficit/surplus) of the foreign sector. But, the fact is that the deficit (liability/ debt) of any sector (including foreign sector) must be equal to its surplus (asset/credit) and their sum also must be zero. The net balance of any sector cannot be negative (deficit/ debt) or positive (surplus/ credit). Therefore, the net current account deficit (surplus) balance cannot the net surplus (deficit) balance of the foreign sector. In the equation of the financial balance model, foreign sector's balance is shown as the difference between the export and import of a government; the aggregate deficit and surplus of all the countries taken together is not shown. Therefore, current account balance of a government cannot be treated as the net (deficit/surplus) balance of whole of the foreign sector.

In the equation, though the balance of private sector is shown as the defferencs between private savings and investment, but in reality only the amount of net budget deficit is shown as the net private savings. The MMT thinks that net deficit budget equals to net private savings. Therefore, the actual savings and investments of the private sector are not shown in the private sector balance. What are shown in the equations in the model of financial balances of three sectors are government's budgetary expenditure and income. Income is shown as the difference between private savings and investment that is net private savings (that equals to government borrowing) and the current account (deficit/surplus) balance that modifies (increases/decreases) the government's net budget deficit. Therefore, the Sectoral Financial Balance approach does not represent the balance of the balances of three financial sectors (government. private and foreign) of the economy. It only shows the budgetary income and expenditure of a government. 


\section{Assessment of the Sectoral Financial Balance Approach:}

The MMT asserts that government's expenditure equals to tax plus deficit spending and deficit spending equals to aggregate sum of government bonds and government bonds equals to surplus of nongovernment sector (the difference between income and tax payment). "For example, in a two-sector model, the government's deficit spending (and thus its net debt issue) is identical to the nongovernment sector's budget surplus (and thus its net accumulation of financial assets, which are claims on the government sector)." [Wray Oct 2009, p.6] "[T] he conclusion from close analysis is that government deficits do lead to net credits to reserves and if excess reserves are created they are drained through bond sales." [Wray Oct 2009, p.8] "By definition, the government's deficit (its spending less its tax receipts) must equal the nongovernment sectors' surplus (receipts from government spending less tax payments). In nominal terms, the equation is guaranteed and we can even assert that it is a position that is desired by the nongovernment sector (for otherwise, it would have spent more - reducing the government's deficit - or less, raising the deficit)." [Wray 2016, p.11]

Then again, the MMT says that "It is well known to students of the National Accounts that the surplus of private disposable income over expenditure is equal to the sum of the government balance (written as a deficit) and the current account balance of payments (written as a surplus)." [Wynne Godley March 2003, p. 2] From this statement it follows that the net government deficit equals to the sum of the government deficit and current account balance; and net government deficit equals to net private savings (surplus over tax or expenditure/ savings minus investment). This means that the current account balance (deficit or surplus) is matched by the nongovernment (private sector) sector's net balance (surplus or deficit). However, the MMT again asserts that the current account balance (surplus or deficit) is matched by the foreign sector's export-import (deficit or surplus) balance. This means, the current account balance (surplus or deficit) is matched twice; once against private sector's balance (deficit or surplus) through matching government bonds bought by the nongovernment (private) sector; and again against the foreign sector's (export-import) balance (deficit or surplus). Here, MMT suffers from self contradiction. If current account balance is matched by private sector's balance then there should not occur any foreign sector's balance. Or, if the current account balance is matched by the foreign sector's balance, then there should not occur any private sector balance (sale of matching amount of government bonds) to match the current account balance.

The MMT argues, "In our two sector model we found that the government's deficit (surplus) must equal the nongovernment sector's surplus (deficit). A similar accounting identity holds for the domestic and external sectors: the domestic deficit (government plus domestic private sector current account deficit) equals the external surplus (capital account surplus). In the three-sector model, the domestic private sector balance plus the government balance equals the external sector balance." [Wray Oct 2009, p.11] Wray writes, "What Godley provided was a stock-flow consistent model that explicitly treated the foreign sector and that used the flow of funds accounts. This was soon added to MMT." [Wray July 2020, p. 19] "The most important takeaway is that the balances must balance, meaning that we cannot think about the government's budgetary outcome independently of the other two balances. Any sector can run a surplus (the sector's income is greater than its spending), but that means at least one other runs a deficit (spending exceeds income). It is not possible to reduce the government's deficit by reducing spending or raising taxes unless the private sector's surplus declines and/or the foreign sector's surplus declines." [Wray July 2020, pp. 19-20]

However, one country's net current account deficit does not reflect the foreign sector's net balance, because the foreign sectoral balance is comprised of balances (credit and debt or asset and liability) of all the trading countries taken together. And, the aggregate export balance (surplus) of all the trading countries is equal to the aggregate import (deficit) of all the countries. Wray writes, "In the three-sector model, the domestic private sector balance plus the government balance equals the external sector 
balance." [Wray Oct 2009, p.11] Then, in the equation of three sectoral financial balance, "Private Saving - Investment $=($ Government Spending - Taxation $)+($ Exports - Imports)" [Fullwiler 2009, p.2], the balance of foreign sector is reduced to balance of "Exports - Imports" of only one of the trading countries. It may be either zero or negative or positive. It does not reflect the balance of net import and net export of all the countries of the globe. The aggregate export minus aggregate import of all the country must be zero and not either negative or positive. Wray writes, "Most importantly, the economy's financial flows are a closed system, so one sector's deficit is another's surplus, and vice versa. There is no way around it, just as it is impossible for every country in the world to have a trade surplus - at least one country must have a trade deficit for the others to have surpluses." [Fullwiler 2009, p.3]

Therefore, one country's current account balance (export-import) (deficit/ surplus) does not reflect the net balance (export-import) (deficit/ surplus) of the whole foreign sector.

According to MMT, "In normal times, the private sector surplus plus the current account deficit equals the budget deficit." [Wray Jan 2012, p.15] Again, "the sectoral balances show that, as a matter of national accounting, the national government deficit (surplus) equals the non-government surplus (deficit)." [Mitchell April 2013, p.13] The MMT asserts that government's net deficit (government deficit plus current account balance) equals to the surplus of the private sector because, according to them, if one sector spends less then another sector must spend more so that the financial position (credit/ debt) of the sectors related to one another through mutual buying and selling balances. "Following Wynne Godley (1996) we can instead use a stock-flow consistent balances approach: a sector's spending flow must equal its income flow plus changes to its financial balance. A sector can spend more than its income, but this implies a deduction from its net financial assets. At the same time, the deficit spending of one sector implies that at least one other sector must be spending less than its income, accumulating net financial assets." [Wray Oct 2009, p.6] "It is useful to divide the economy into three sectors: government (national, state, and local), domestic private (households and firms), and foreign (rest of the world). If one sector spends more than its income (deficit), at least one other must spend less than its income (surplus) to maintain the aggregate identity that total spending equals total income. The balances (income minus expenditure) of the three sectors have to add up to zero since we are adding up all the income in the economy and subtracting all the spending, which are equal by identity." [Wray Nov 2019, p.9] "It is the deficit spending of one sector that generates the surplus (or saving) of the other; this is because the entities of the deficit sector can, in some sense, decide to spend more than their incomes, while the surplus entities can decide to spend less than their incomes only if those incomes are actually generated. ... Here, however, the statement is that the government sector's deficit spending generates the nongovernment sector's surplus (or saving)." [Wray Oct 2009, pp.6-7]

It means one sector's financial balance (deficit/ surplus) is matched by the other sectors' balances (surplus/ deficit). So they argue that government's deficit is matched by the nongovernment sectors' (private plus foreign) surplus (claims on the government). The MMT also argues that "private net saving is always identically equal to the government's budget deficit plus the current account surplus." [Wynne Godley Nov. 2007, p. 2] "The government and nongovernment are thus inextricably bound in an inescapable balance. It makes no sense to talk about a government deficit as either imbalanced or unsustainable. A government deficit will result if the nongovernment sector has a surplus-a perfect balance." [Wray Nov. 20012, p.19] "At the aggregate level, a government deficit is offset by (and identically equal to) a nongovernment surplus; and a government surplus is offset by a nongovernment deficit. The government's budget can "balance" (spending equals taxes) only if the nongovernment sector's budget "balances" (spending equals income)." [Wray Nov. 20012, p.19] Godley wrote: "[T]he deficit of the general government (federal, state, and local) is everywhere and always equal (by definition) to the current account deficit plus the private sector balance (the excess of private saving over investment)." [Wynne Godley June 2005] This formula of sectoral balance identity can be expressed as: (Savings - Investment $)+$ (Imports - Exports $)+($ Tax Revenues - Outlays $)=0$; 
or $(\mathrm{S}-\mathrm{I})+(\mathrm{M}-\mathrm{X})+(\mathrm{T}-\mathrm{G})=0$. However, in this equation, the aggregate income and aggregate expenditure of the private sector are not shown. Only the net savings (savings minus investment) of the private sector is shown. According to this definition, savings (surplus) of the private sector must be equal to the aggregate deficit of the other two sectors (government and foreign) taken together. Therefore, "private net saving is always identically equal to the government's budget deficit plus the current account surplus." [Wynne Godley Nov. 2007, p. 2] This equation may be written as "Private Saving - Investment = (Government Spending - Taxation) + (Exports - Imports)" [Fullwiler 2009, p.2] or, -"This is also referred to as net saving of the private sector since investment is a type of expenditure and saving is what is left after consumption. In other words, we are looking at what is left of disposable income after the private sector consumes and invests.] [Wray Nov 2019, p.9]

However, the MMT does not bother to show the actual savings and investment when calculating the net savings position of the private sector. It argues that the net savings of private sector equals to the amount of bonds issued by the government. Wray writes, "It is not possible for the nongovernment sector's balance to differ from the government's balance; this also means it is impossible for the aggregate saving of the nongovernment sector to be less than (or greater than) the budget deficit. It is also obvious that the non-government savings cannot exist before the budget deficit ... both the resulting budget deficit as well as the non-government's savings of net financial assets are residuals and are equal." [Wray Oct 2009, p.8] Therefore, they put the amount of government bonds in place of "Savings - Investment" in the equation. The MMT argues, "It is also obvious that the nongovernment savings cannot exist before the budget deficit. ... both the resulting budget deficit as well as the non-government's savings of net financial assets are residuals and are equal." [Wray Oct 2009, p.8] But, it is wrong to think that if government does not deficit spend, private sector cannot have surplus. Private sector must have surplus first, then only it can buy government bonds with that surplus. Government does not determine the amount of its deficit spending on how much surplus the private sector has. Therefore, deficit spending cannot be equal to the surplus of the private sector.

However, the relation between the government and private sector is not of buying and selling. Government only buys from the private sector and does not sell anything to the private sector; and the private sector only sells to the government and does not buy anything from government. Besides, selling of government bonds is not really selling; it borrowing, and buying of government bonds is not really buying or saving, it is lending. So, the financial balance (deficit/ surplus) of one sector (government/ private) cannot be matched by the balance (surplus/ deficit) of the other sector (private/ government). It is wrong argument of the MMT that government's deficit must be matched by the surplus of the private sector. Government just borrows money from the private sector and does not earn any money through selling anything to the private sector. The government may or may not borrow, but that does not mean that private sector must not have any wealth saved for its future use.

The MMT says that government's deficit equals the net surplus or wealth (financial claim on the government) in the form of government bonds) of the nongovernment (private) sector. The MMT equates aggregate surplus of nongovernment sector with aggregate savings, and aggregate saving savings with aggregate government bonds (net government deficit). It means if the government does not deficit spend then there should not exist any net surplus or wealth of the nongovernment (private) sector. However, the MMT is oblivious of the fact that if the government does not deficit-spend, even then, the money, that the nongovernment sector uses to buy government bonds, will remain in their wallets or banks. Yes, the private sector will not possess any government bonds (claims on the government) if government does not deficit spend; but that does not mean that the nongovernment sector will not have any surplus (less spending than income). However, the fact is that the nongovernment (private) sector keeps their savings in their wallet or in the banks. Therefore, the arguments that aggregate private surplus equals to aggregate private savings; and that aggregate private savings equals to aggregate government bonds is wrong. 
To come out of such fallacy, the MMT argues that the non-government sector includes households, firms and banks. So, to them, net surplus of nongovernment sector implies the overall surplus of all the households, firms and banks. However, even if we consider that the surplus of nongovernment sector includes net surplus of all these (households, firms and banks) taken together, yet the net surplus of nongovernment sector does not equal to the net government borrowing (deficit spending) in the form of government bonds. The MMT argues, in their sectoral financial balance approach, that government spending equals to the sum of tax and bond sale, and the banking sector (representing nongovernment sector as a whole) receives the money ("reserve" according to MMT) that the government spends into existence; and that the treasury withdraws the whole amount of that reserve through tax and selling bonds from the banking sector. It implies after the tax is paid and government bond is bought, there should not remain any reserve in the banking sector. Then there should have no money in the economy for the private sector for buying and selling their necessities. However, after paying tax and buying government bonds the nongovernment sector (households, firms and banks) does have money with which they buy things, invest in production and hold money (either in their wallet or in the banks) for future use. Therefore, it is not the fact that the government is the only source of money. Rather, government is not at all a source of money. Government does not spend money into existence; it only spends what it gets as tax and from bond-sale. The economy gets money from the central bank only when the central bank lends to its borrowers. The money begins to circulate as the borrowers begin to spend. Government earns money through exacting tax on the nongovernment sector and borrows from the nongovernment sector through bond selling. However, more money remains in the economy after the tax is paid and government bonds are bought. This excess money is used by the private sector for buying, investing and holding.

The MMT argues that private (nongovernment) sector gets money from the government through selling commodities. So to help nongovernment sector to be able to spend more, government should spend more money and if it becomes necessary government should deficit spend. However, the MMT also argues that government should deficit spend so that the nongovernment sector may save and that the net deficit spending is equal to net borrowing (government bonds). It implies that government deficit spends so that private sector can increase their savings and not spend. If deficit spending helps only to increase wealth (claims on the government) and does not help nongovernment sector to spend; then increasing deficit spending becomes purposeless.

Sectoral financial balance approach considers that there is a vertical transaction of stock and flow of money ("reserve" according to MMT) between the treasury and the banking sector. Wray writes, "the financial processes are not hard to understand. Government spends (purchasing goods and services or making "transfer" payments) by crediting the bank accounts of recipients; this also leads to a credit to their bank's reserves at the central bank. The government taxes by debiting taxpayer accounts (and the central bank debits reserves of their banks). Deficits over a period (say, a year) mean that more bank accounts have been credited than debited. The nongovernment sector realizes its surplus initially in the form of these net debits to bank accounts. All of this analysis is reversed in the case of a government surplus: the government surplus means the nongovernment sector runs a deficit, with net debits of bank accounts (and of reserves)." [Wray Oct 2009, p.7] "[T] he conclusion from close analysis is that government deficits do lead to net credits to reserves and if excess reserves are created they are drained through bond sales." [Wray Oct 2009, p.8] "In conclusion, deficit spending by the treasury leads to a net credit of reserves for the banking system, regardless of the operating procedures chosen. These are drained through bond sales (even if the operating procedures require that the bonds are sold in anticipation of the deficit spending). If this were not done, excess reserves in the banking system would drive the overnight interest rate down." [Wray Aug. 2003, p.10] "[B]anks act as intermediaries between government and the nongovernment sector, crediting deposits as government spends and debiting them when taxes are paid." [Wray Oct 2009, p.5] "[G] overnment deficits [spending] mean net credits to banking system reserves and also to nongovernment deposits at banks" [Wray Oct 2009, p.5] 
When government spends, the reserve is transferred from the treasury and accumulated in the sellers' account in the banking sector. And the same reserve is transferred from the banking sector again to the treasury when the private sector pays tax and buys government bonds. However, this explanation of a vertical and perfect balance between the government and the nongovernment sector is wrong. It is not true that the treasury spending is the only source of reserves of the banks. The MMT forgets that there is also a vertical transaction between the banking sector and the banking department of the central bank, because when the central bank lends money (reserve) to the banking sector and some of the reserve is transferred from the banking sector to the central banks when the banking sector keeps reserves in its account held in the central bank and repays its debt to the central bank. Besides, vertical transactions also exist between the banking sector and households \& firms through borrowing, repayment and investment etc. Therefore, the flow of funds to and from the banks is not equal to but more than the flow of funds to and from the treasury. Therefore, balances of the government sector and the non-government sector do not balance perfectly as the MMT claims it to be by there sectoral financial balance approach.

However, it is assumed (by MMT) that all the reserves that are earned by the sellers to the government is accumulated in the banking sector and money (reserves) are transferred between the sellers account and the buyers account held in the banking sector without withdrawal of any money from the banking sector for the private use of the households and firms. Because, if reserve is withdrawn by the households of firms, then treasury will not be in a position to drain (through tax and bond-sale) the amount of reserve that it spends into existence. However, the recipients (who sells commodities to the government) of reserves do not keep all of their income in the banks. They withdraw certain amount of reserve for buying in the retail market. Therefore, the vertical transfer or stock and flow of reserves between the Treasury and the banking sector cannot justify the sectoral financial balance approach of balancing the balances of three inter-connected sectors (government, private and foreign) sectors.

As the vertical flows of funds to and from the treasury are equal, then it must be admitted that the budgetary spending and income (through tax and bond-sale) of the government are equal. It also proves that contrary to the assertion of MMT that government does not need tax and bond-sale, government really needs tax and bond-sale to finance its budgetary expenditure.

Wray writes, "By definition, the government's deficit (its spending less its tax receipts) must equal the nongovernment sectors' surplus (receipts from government spending less tax payments). In nominal terms, the equation is guaranteed and we can even assert that it is a position that is desired by the nongovernment sector (for otherwise, it would have spent more - reducing the government's deficit - or less, raising the deficit). [Wray 2016, p.11] However, if government drains (as tax and bond-sale) all the reserve (money) that it spends then private sector must have no money to be able to spend and invest. The MMT does not tell wherefrom the private sector gets the reserve (money) for spending and investing other than paying tax and buying government bonds. Therefore, the sectoral financial balance approach cannot clearly establish that there is a perfect balance of flow of funds between the government sector and the non-government sector.

The sectoral financial balance approach says that one sector's spending is matched by other sector's income and that one sector's spending more than its income (deficit spending) is matched by saving (financial asset, claims on the deficit sector) of other sector(s). "Britain's Wynne Godley developed the concept of sectoral balances, which focuses on the accounting truth that when the government runs a deficit, the nongovernment sector must run a surplus, and vice versa." [Peter Coy, K. Dmitrieva and M. Boesler March 2019] However, if the private sector spends more than its income, no savings (asset, claim on the private sector) is made in the government sector, because the private sector does not buy any 
commodity (other than government bonds) from the government (or, government does not sell anything to private sector).

The sectoral financial balance approach says that the only source of private sector's income is spending by the government. Therefore, government should spend so that private sector can earn to spend. However, if private sector spends more than its income, it becomes indebted to the corporate sector (including banking sector) and not to the government sector. The sectoral financial balance approach pleads for spending (even deficit spending if necessary) so that the private sector need not to borrow (becomes indebted to corporate sector). Wynne Godley advocates in favor of deficit spending so that private sector may earn more, because he thinks that excessive indebtedness of the private sector is not sustainable beyond a certain limit. "In the first of these papers, published in 1999, at a time when there was an emphatic consensus that "the good times were here to stay," we took the contrarian view-well ahead of the curve - that unsustainable imbalances were building up that would eventually require both a large fiscal stimulus and a sustained rise in net exports, preferably via a substantial depreciation of the dollar." [Godley, Papadimitriou and Zezza, Dec. 2008, p.1] Wynne Godley is also of the view that increase in government deficit spending is also not sustainable beyond a certain limit, so he did not favour deficit spending beyond certain percentage of GDP. However, Wynne Godley warns of the private sector indebtedness. He writes, if rise of private expenditure relative to income "were to continue for another eight years, the implied indebtedness of the private sector would then be so extremely large that a sensational day of reckoning could then be at hand." [W. Godley 1999, p. 11] "As early as 2004, in a Strategic Analysis subtitled Why Net Exports Must Now Be the Motor for U.S. Growth, we argued that continued growth in net lending to the private sector was an impossibility, and that at some stage there would have to be a collapse both in lending and in private expenditure relative to income." [Godley, Papadimitriou and Zezza Dec. 2008, p.2] "We also argued that it would not be possible to save the situation by applying another fiscal stimulus (as in 2001) because that would increase the budget deficit to about 8 percent of GDP, implying that the public debt would then be hurtling toward 100 percent of GDP, with more to come." [Godley, Papadimitriou and Zezza Dec.2008, p.2] "As the turnaround in net lending eventually became manifest, we predicted in our November 2007 analysis - without being too precise about the timing - that there would be a recession in 2008." [Godley, Papadimitriou and Zezza Dec.2008, p.2] "The budget deficits imply that the public debt relative to GDP would rise permanently to about 80 percent, while GDP would remain below trend, with unemployment above 6 percent. Fiscal policy alone cannot, therefore, resolve the current crisis. A large enough stimulus will help counter the drop in private expenditure, reducing unemployment, but it will bring back a large and growing external imbalance, which will keep world growth on an unsustainable path." [Godley, Papadimitriou and Zezza Dec. 2008, p.4] "By our reckoning (which is put forward with great diffidence), if the United States were to attempt to restore full employment by fiscal and monetary means alone, the balance of payments deficit would rise over the next, say, three to four years, to 6 percent of GDP or more - that is, to a level that could not possibly be sustained for a long period, let alone indefinitely." [Godley, Papadimitriou and Zezza Dec. 2008, p.6] "U.S. residents would have to stop absorbing 5 percent more goods and services than they produce, with the corollary that fiscal policy would have to become tighter than at present, not looser as in our base projection.” [Wynne Godley 2003 March, p. 7]

It appears from above statements of Wynne Godley that he was concerned about the increase in private sector's indebtedness. At the same time, he also did not favour increasing government deficit beyond a certain limit to help increase private sector's income.

However, Wray, one of the chief spokesman of the MMT, argues that government should increase its deficit spending so that private sector can save (buy government bonds) more. Wray writes, "In aggregate, there can be no net savings of financial assets of the nongovernment sector without cumulative government deficit spending. Government (via deficits) is the only entity that can provide the nongovernment sector with net financial assets (net savings) and thereby simultaneously accommodate any 
net desire to save in the unit of account and hence eliminate unemployment." [Mitchell April 2013,p. 9] "[T] he current crisis will not be resolved until the budget deficit expands sufficiently to satisfy the net saving desires of nongovernment sectors in the form of currency, reserves, and Treasury debt." [Wray Oct 2009, p.6]

Wray even argued that until the nongovernment sector's appetite for saving is satisfied, the government should keep on increasing its deficit spending. He writes, "We will come to rest where the higher government deficit equals the higher nongovernment sector's desired surplus. This is in line with the sectoral balance approach discussed previously: the sum of the balances across sectors is zero." [Wray Nov 2019, p. 14] "[T] he government deficit has to be greater than the current account deficit to allow the domestic private sector to net save." [Wray Nov 2019, p. 20] "[T] government's budget outcome should be to allow the private sector to normally net save (run a surplus)." [Wray Nov 2019, p. 21]

Wray reasons that increase in deficit spending will help economy to grow robustly; and this will increase people's ability to pay tax at an increasing rate; and that will help to reduce deficit spending later. He writes, "attempts to reduce (or increase) the size of the federal deficit can be thwarted by movements of the other balances. On the other hand [if deficit spending is increased], faster growth could reduce deficits without necessarily producing fragile finances in the domestic private sector. As we have seen, two important factors that can affect the budgetary outcome are movements of tax receipts and transfer payments, both of which are influenced by the growth rate of GDP. As growth picks up, revenue grows faster and transfer payments grow more slowly (or even fall) - which would together tend to reduce the size of the federal deficit." [Wray Nov 2019, p. 12] "[I]f the private [p. 13] sector's surplus declined along with a reduction of the budget deficit in a period of slow growth, that would be a "bad" way to lower the deficit, as servicing private debt could be difficult." [Wray Nov 2019, pp. 12-13] "For example attempts to lower the deficit could be counterproductive as they could lower the rate of growth of GDP and thus increase the budget deficit as private sector spending declines." [Wray Nov 2019, p. 13] "if government stimulus boosts growth (through increased spending or tax cuts), the deficit ratio could fall and even move into surplus." [Wray Nov 2019, p. 20-21] "we may choose to boost growth through proactive fiscal policies which could then increase tax revenues and reduce transfer spending, thus lowering the deficit. Because the deficit or the debt ratio is not a good indication of economic performance, it should not be the focus of policymaking in any case." [Wray Nov 2019, p. 22]

However, Wray advocates argues in favour of government's deficit spending not to help the private sector to earn more to be able to spend more or to be able to repay their debt to the corporate sector, but to help the private sector to earn more so that they can buy more government bonds with their extra income. However, he contradicts himself when he argues that government should increase its deficit spending until full employment is reached. Wray argues that deficit will not increase further once full employment is achieved. If government's deficit spending helps the private sector to buy government bonds of equal amount of government deficit, then how deficit spending will help government to spend for achieving full employment.

Wray is wrong when he asserts, "Just as government deficits add to private sector surpluses, government debt adds to private sector net financial wealth (again, holding the external balance constant). Indeed, the total wealth of the private sector as a whole consists of real assets, claims on foreigners and claims on the government, i.e., government bonds plus currency, since private assets and liabilities add up to zero (within the private sector, someone's asset is someone else's liability). Hence growing federal government debt implies that the private sector is accumulating net financial wealth." [Wray Nov 2019, p. 21] If "private assets and liabilities add up to zero (within the private sector, someone's asset is someone else's liability)", and the income is treated as asset, then earning of private sector by selling commodities to the government must be accounted as their asset. Then, it is contradictory to assert that "growing 
federal government debt implies that the private sector is accumulating net financial wealth", because government does not just give away money to the private sector (government buys commodity with money when it deficit-spends. Therefore, the money (that the private sector earns must be included in their "assets and liabilities" that add up to zero. This asset cannot be treated as extra (surplus) wealth that the private sector is supposed to be "accumulating net financial wealth".

The MMT is wrong when it argues that reduction in deficit spending or balanced budget or surplus budget leads to nongovernment deficit or destroys the wealth of the nongovernment sector. Wray writes, "At the aggregate level, a government deficit is offset by (and identically equal to) a nongovernment surplus; and a government surplus is offset by a nongovernment deficit. The government's budget can "balance" (spending equals taxes) only if the nongovernment sector's budget "balances" (spending equals income)." [Wray Nov. 20012, p.19] "[I]n the case of a government surplus: the government surplus means the nongovernment sector runs a deficit, with net debits of bank accounts (and of reserves)." [Wray Oct 2009, p.7] "the government surplus means the nongovernment sector runs a deficit, with net debits of bank accounts (and of reserves). The destruction of the nongovernment sector's net financial assets, of course, equals the budget surplus." [Wray Oct 2009, p.7] Mitchell also subscribes to this view of Wray. He writes, "Budget surpluses either destroy private wealth by forcing the private sector to liquidate its wealth to get cash or destroy liquidity (debiting reserve accounts), which is deflationary." [Mitchell April 2013, p.13]

From these assertions of the MMT, it appears that government's deficit means creation of asset (financial claim on the government in the form of government bonds) for the nongovernment (private) sector, and that deficit of the nongovernment sector means equal amount of asset (financial claim on the nongovernment sector in the form nongovernment bonds) or similar financial instrument (issued by the nongovernment sector) must be accumulated by the government. However, there exists no such financial instrument that is an asset of the government and a claim on the nongovernment sector.

However, it is wrong to argue that surplus of the government sector leads to the "destruction of the nongovernment sector's net financial assets" because if government debt is beyond the asset-liability balance (that must be zero), then reduction of deficit spending does (can) not destroy the wealth of the private sector; it only creates less government bonds (that are claims on the government) than if the government would more deficit-spend. And definitely, it does not force the nongovernment sector to undergo a deficit.

MMT's opinion is that government issues government bonds just to help quench saving appetite of the nongovernment sector. But, if nongovernment sector is not willing to save as much as the government wants to deficit-spend, in that case, Wray suggests that government should increase interest rate to such an extent so that people is lured to buy all the government bonds that the government wants to sell. He writes, "How can we be sure that the budget deficit that generates accumulation of claims on government will be consistent with portfolio preferences, even if the final saving position of the nongovernment sector is consistent with saving desires? The answer is that interest rates (and thus asset prices) adjust to ensure that the nongovernment sector is happy to hold its saving in the existing set of assets. Here we must turn to the role played by the government's interest-earning debt ("treasuries" or bills and bonds)." [Wray Oct 2009, p.8-9, emphasis is added] Wray even argues that if the banking sector does not want to buy government bonds even at the increased interest rate, then government must force the banks to buy such amount of bonds as the government wants to sell. He writes, "Treasury might need to sell bonds in the new issue to obtain the deposits at the Fed that will be debited. Dealer banks must stand ready to buy these new issues, or else risk their status as primary dealers." [Wray Nov 2019, p. 21]

Therefore, it is not true that government does not sell bonds for funding its expenditure but for maintaining overnight rate of interest (as the MMT claims it to be). It is not also correct that the government sells bonds only to help nongovernment sector to save and earn more interest (as the MMT 
claims it to be). If these are the reasons why government sells bonds, then it is not necessary to increase interest rate so that all the bonds that the government wants to sell can be sold. It is also not necessary to threat the banking sector that if they don't buy bonds their status as "primary dealers' will be cancelled. Therefore, it is clearly understood that government itself decides how much deficit it will create because it needs money to fund its spending. Yet, the MMT will argue that, "Government actually spends by crediting bank deposits (and simultaneously crediting the reserves of banks)... This is a key to understanding why perpetual budget deficits are 'sustainable' in the conventional sense of that term... Indeed, we argue that modern sovereign governments spend by crediting bank accounts - they do not really spend tax revenue, nor do they borrow by selling bonds." [Nersisyan and Wray 2010, p. 11; quoted in Fiebiger 2013, p.65]

Wray could not understand why the selling of bonds is called as government's borrowing, He writes, "Government spending puts reserves into the banking system, while taxing and bond sales remove them. Why would we call it a fiscal borrowing operation when it is done by the treasury, but a monetary policy operation when done by the central bank?" [Wray July 2020, pp. 15-16] The fact is that selling of bonds by the central bank is not borrowing; it is selling because in this case, the exchange between bonds (held by the central bank and sold to the bond-buyers) and money (held by the bond buyers and paid to the central bank) is full and final; none of the central bank and the bond-buyers become indebted or creditor to one another after this exchange. The purpose of selling bonds by the central bank is to reduce supply of money in circulation. Therefore, bond-selling (for reduction of supply of money with a view to control inflation from rising) is called a monetary policy operation. But, selling bonds by the government is not really selling; it is borrowing, because, after selling bonds, government becomes indebted to the bondbuyers and becomes bound to repay the debt and accrued interest on the bonds according to the terms of the bonds. The purpose of bond-selling by the government is to use the proceeds in spending. Therefore, selling of bonds by the government is called a fiscal borrowing operation.

Wray also contradicts himself regarding the composition of government expenditure. He writes, "Government spending puts reserves into the banking system, while taxing and bond sales remove them." [Wray July 2020, pp. 15-16] This means that government spending equals to tax-receipt and proceeds from bond-sale. In the same page, he asserts that government uses taxes, bonds and money [printing money] for spending. He writes, "[T] he "financing" always takes the form of a credit to bank reserves (and a credit by a private bank to the recipient's account) - government doesn't "choose" whether to use taxes, money, or bonds. Indeed, spending normally involves all three even if the budget ends up "balanced" or in surplus at the end of the accounting period." [Wray July 2020, p. 17] In the later equation, he adds "money printing to pay for the spending.". However, he did not explain how money printing helps government spending over and above its spending that it removes from banking sector through tax and bond-sale.

"[T] he "financing" always takes the form of a credit to bank reserves (and a credit by a private bank to the recipient's account) - government doesn't "choose" whether to use taxes, money, or bonds. Indeed, spending normally involves all three even if the budget ends up "balanced" or in surplus at the end of the accounting period." [Wray July 2020, p. 17] He also writes," There is no such thing as special "deficit financing"-government is "financed" as it spends, with a deficit recorded only ex post." [Wray July 2020, p. 17] However, he is wrong is suggesting that deficit is an ex post accounting. In the same page, he himself wrote that before spending over income from tax, government either takes overdraft from the central bank; or if central bank does not provide overdraft then the government sells bonds to finance its deficit spending. He argues if banks don't have enough money to buy new issues of government bonds, then the central bank provides the banks with requisite amount of money through lending of through buying government bonds that the banks have bought earlier. He writes, "They still may be needed because of operational procedures adopted-for example, the prohibition against central bank provisioning of overdrafts for the treasury. In that case, a treasury might sell new issues before 
spending-which requires that the central bank ensures banks have the reserves they will need to purchase the bonds. This is accomplished by lending reserves or through open market purchases coordinated with the treasury's new issue. However, the central bank can always remove the new bonds from markets through, for example, "quantitative easing" (QE)”. [Wray July 2020, pp. 17-18]

While Warren B. Mosler, the founding father of MMT argues that savngs makes economic growth sluggish, Wray pleads for more private savings. Mosler wrote, "Putting part of one's salary into a savings account means only that an individual has not spent all of his income. The effect of not spending as such is to reduce the demand for consumption below what would have been if the income which is saved had been spent. The act of [p 11] saving will reduce effective demand for current production without necessarily bringing about any compensating increase in the demand for investment. In fact, a decrease in effective demand most likely reduces employment and income. Attempts to increase individual savings may actually cause a decrease in national income, a reduction in investment, and a decrease in total national savings. One person's savings can become another's pay cut. Savings equals investment. If investment doesn't change, one person's savings will necessarily be matched by another's' dissavings. Every credit has an offsetting debit. 43 -P 8 -The Fed's desire to maintain the target fed funds rate links government spending, which adds reserves to the banking system, and government taxation and borrowing, which drain reserves from the banking system. Under a fiat monetary system, The government spends money and then borrows what it does not tax, because deficit spending, not offset by borrowing, would cause the fed funds rate to fall." [Mosler 1995, pp. 10-11] "Low spending can put the economy in the doldrums: low sales, low income, low investment, and low savings." [Mosler 1995, p. 11]

The fact is that the MMT economists are willfully and knowingly maneuvering or distorting the facts to furnish a case in favour of its agenda of full employment. Deficit spending by the government is not favoured as this increases the debt-burden of the government. To wipe out the aversion to deficit spending, the MMT argues that government's deficit is private sector's wealth (claims on the government) and increase in deficit spending by the government leads to increase in wealth (government bonds) of the private sector. The MMT presents deficit spending in such a way as if nothing is to be worried if claims on the government increases because increase in claims on the government means increase in wealth of the private sector and because government can spend money into existence. However, this is not the fact. If government can spend money into existence why its deficit spending must be equal to the government bonds, why government cannot deficit spend more than government bonds, if bond selling is required not to finance government spending but only for maintaining the interest rate by the central banks.

Therefore, sectoral financial balance approach does not really reflect the balances among the balances of three sectors. It is only reflects the income and expenditure of the budget of a government. Income and expenditure (deficit and surplus or saving, asset or claims on other sectors and liability to other sectors, spending and expenditure, debt and credit) of other two sectors (private and foreign) are not reflected fully and properly in this approach. This approach is a fantasy that does not corroborate to the reality. Therefore, there is no balancing relation of financial balances between the government and the nongovernment sector. In MMT's equation, the private sector's balance is "Private Sector Surplus or Net Saving [Savings minus Investment] $=$ Government Deficit + Current Account Balance [Foreign Sector Balance]" [Fullwiler 2009, p. 3] The savings of private sector only through buying government bonds (and not through saving in the banks or other expenditure and investment) is reflected in the so-called financial balance approach to government's budget (income and expenditure) balances. This approach does not reflect the aggregate income and expenditure or asset and liability or credit and debt of the private (or non-government) sector. This approach reflects income and expenditure (financial balances) 
only of the government budget and in no way of either the private sector or the foreign sector. Therefore, sectoral financial balance approach is nothing but a fantasy of the MMT economists.

The sectoral financial balance approach shows only the net budget balance (income and expenditure) of the concerned country. It does not reflect the net balance (income/ expenditure or asset and liability or credit/debt) either of the private sector or of the foreign sector. Therefore, the approach that balances among three sectors of economy (government, private and foreign) balance is a myth and not an accounting of real financial balance among these three sectors.

\subsection{The MMT wrongly consider all - commodity like wheat or barley, coupons like clay tablets, tax-slips like wooden tally sticks, commodity money like metal coin and token (representative) money like paper money - as credit (debt) instruments.}

MMT writes, "Money, recorded as a debt dominated in a unit of account, would be created as part of a forward debt contract. Money acting as a medium of exchange or means of payment would take a physical form (wheat or barley, and later, clay tablets, wooden tally sticks, metal coins, or paper IOUs), denominated in terms of the idealized money of account. " [Wray 2012 May, p. 20] MMT freely uses interchangeably the terms 'money of account', 'unit of account', 'monetary instrument', 'money thing', 'forward debt contract, 'credit', and 'debt' to mean only credit (debt) instrument. Wray writes, "These "monies" did not function as media of commercial exchange, they did not function as common measures of value, they did not act as the standard of deferred payment" [Wray May 2012, p. 10] "The origins of money are not to be found, then, in a hypothesized exchange society based on barter. Instead, money develops as a unit of account, or, as the terms in which debts are written" [Wray May 2012, p. 15] Following Innes, Wray argues, "Rather than selling in exchange for "some immediate commodity called the "medium of exchange", a sale is really "the exchange of a commodity for a credit". Innes called this the "primitive law of commerce". "The constant creation of credits and debts, and their extinction by being cancelled against one another, forms the whole mechanism of commerce ..." Innes 1913, p. 389) ... The market then, is not viewed as the place where goods are exchanged, but rather as a clearing house for debts and credits." [Wray May 2012, p. 23] According to the MMT, "the money of account and those credit-debt relations are the key institutional relations of the capitalist economy.” [Wray May 2012, p. 24]

-"throughout most of Europe's history, the money-thing issued by the state was the hazelwood tally stick .... Other money-thing included clay tablets, leather and base metal coins, and paper certificates. Why would the population accept otherwise "worthless" sticks, clay, base metal, leather, or paper? Because these were evidence of the state's liabilities that it would accept in payment of taxes and other debts owed to itself." [Wray May 2012, p. 26]

The MMT cannot think of existence of any debt-free money like commodity-money. In "Debt-Free Money and Banana Republics", Wray writes, "All money, save bananas in your monkey republic, is debt." [Wray Dec. 2015] "I don't think our debt-free money cranks really want government to "issue" bananas. I think they want a "money" that is a record. But a record of what? If not debt, what?" [Wray Dec. 2015] "But what are notes or electronic entries? They are records of indebtedness - debts that can be redeemed in payments to the issuers. They are debt tokens, redeemable in payments of debts owed to their issuers." [Wray Dec. 2015] 
Though, Wray argues that he wants to define money in the context of how and why the present capitalist system uses money. He asserts that in capitalist system, "The purpose of production is to accumulate money - not to barter the produced commodities for other commodities." [17 -Wray Dec 2010, p.4] and "We have argued that money is not a commodity, but we have not said much about what it is, beyond arguing that it is a unit of account. ... the dollar, the euro, the yen - that is impossible." [17 -Wray Dec 2010, p.5] and "We conclude: money is debt. It need not have any physical existence other than as some form of record-mostly, an electrical entry on a computer." [17 -Wray Dec 2010, p.9-10] However, later, he declares that does not want to define money in the context of how capitalist economy use it but in the context how government can use it. He writes, "I will fiocus more on the role played by money in relation between the state and its public rather than on the role played by money within the private sphere. That is, my focus here is on the role played by money in promoting the 'public purpose' rather than the 'private purpose' (for example, to finance profit-seeking behaviour of private capitalistoic firms)." [Wray 2013, pp. 79-80] "The central idea of the alternative view is that the value of money is based on the power of the issuing authority, and not by any embodied or backing precious metal. Hence, Chartalists give a central role to the state in the evolution and use of money. For the most part, this evolution is not linked to reduction of transactions costs of exchange. Rather, the evolution of money is linked to the needs of the state to increase its power to command resources through monetization of its spending and taxing power. Thus, money and monetary policy are intricately linked to political sovereignty and fiscal authority." [Wray 01 July 2000, p 4]

Now, let us explain whether these things (wheat or barley, and later, clay tablets, wooden tally sticks, metal coins, or paper IOUs), were / are debt-instruments or not.

\subsection{A. Wooden Tally Sticks were not debt-instruments and did not circulate as "monetary (credit) instrument in the economy:}

Wray argues that at first, the Kings used to receive tax, fines, tithes, rents, tributes and fees through inkind payments. Later, Kings changed their mode of tax-receiving. Kings' treasuries began to keep accounts of all these receipts (of tax, fee, fine etc.) in units (Wray calls it 'money unit'). Wray writes, "Palaces created the money unit to simplify accounting." [Tymoigne \& Wray July 2005, p. 8] Wray argues that thereafter, Kings began to issue wooden tallies (instrument of tax obligation) to his tax payers. He writes, "Once a money rent, tax or tribute was levied on a village, and later on individuals, the palace would be able to obtain goods and services by issuing its own money denominated debt in the form of tallies." [Tymoigne \& Wray July 2005, p.8] Wray explains why the Kings began to use tallies thus: "While government could in theory require [tax] payment in the form of all the goods and services it requires, this would be quite cumbersome. Thus it becomes instead a debtor to obtain what it requires, and issues a token (hazel wood tally or coin) to indicate the amount of its indebtedness; it then accepts its own token in payment to retire tax liabilities." [Tymoigne \& Wray July 2005, p. 10] Here, Wray is confused when he argues that coin issued by the ruling authority (the king) is a debt-instrument and that government's ability to force its citizens to be debtor [tax-payer] and to pay tax in that coin. The fact is that governments in olden days used to both collect tax and issue coins; coins were not issued as sovereign debt and taxes were not collected only in coins. Wray writes, "most tax collections brought in far more hazelwood tally sticks than coins." [Wray Nov. 2016, p.4] This is because tally-sticks were the records of how much of what commodity should be paid by the holder of those tally sticks and coins were not records of debt or tax. Coins were paid as tax. 
Wray is misled by wrong theories formulated by some earlier economists. Quoting Innes he writes "Just like any private individual, the government pays by giving acknowledgments of indebtednessdrafts on the Royal Treasury, or some other branch of government. This is well seen in medieval England, where the regular method used by the government for paying a creditor was by 'raising a tally' on the Customs or some other revenue-getting department, that is to say by giving to the creditor as an acknowledgment of indebtedness a wooden tally. (Innes, 1913, p.397-8)" [Tymoigne \& Wray July 2005, p. 9] Citing this quotation, Wray wants to make us believe that the government would exchange its "wooden tally" as its IOUs ("acknowledgment of indebtedness") to the sellers from whom the government would buy some goods or services. However, Wray is wrong in considering those wooden tallies as money (or according to Wray a monetary instrument) because those tallies were not used as IOU (monetary instrument) to buy anything but were given to those from whom government wanted to get tax payments. The quotation that Wray uses in favor of his argument proves that those tallies were instruments in which it was written what things in what quantities should be paid by the chosen taxpayers. Quoting Innes, Wray writes "The government by law obliges certain selected persons to become its debtors. It declares that so and- so, who imports goods from abroad, shall owe the government so much on all that he imports, or that so-and-so, who owns land, shall owe to the government so much per acre. This procedure is called levying a tax, and the persons thus forced into the position of debtors to the government ... When these are returned to the government Treasury, the taxes are paid. ((Innes, 1913, p.398) [Tymoigne \& Wray July 2005, p. 9] Here Wray clearly accepts that those wooden hazelwood tallys, in which payable taxes are written, are issued to the tax-payers. Tallies comprised of two parts called "the stock and the stub" in both of which was written who would pay how much of what commodity to the government. When the receiver (or the chosen taxpayer) of the tally-stick would return the tally stick to the exchequer (tax receiving office), then his tax (according to Wray debt) would be redeemed. However, just returning tally-stick would not redeem the tax-liability of the tax-payer to the King, as Wray wants us to believe. Return of tally stick must be accompanied by the commodities of the same weight and quantity as was written on the tally stick. Wray writes, "The sticks were split into stock and stub, matched at the time of redemption and then destroyed." [Wray Nov. 2016, p.4] Therefore, tallystick was neither an instrument of debt nor an instrument with which taxes were paid.

Wray is wrong when he argues that tally sticks were used as money and that taxes were paid in tallies (as money). Quoting Innes Wray writes, "Innes went on to note that the vast majority of revenues collected by inland tax collectors in England were in the form of the exchequer tallies: [p]ractically, the entire business of the English Exchequer consisted in the issuing and receiving of tallies, in comparing the tallies and the counter-tallies, the stock and the stub, as the two parts of the tally were popularly called, in keeping the accounts of the government debtors and creditor " (Innes 1913, p. 398)" [Tymoigne \& Wray July 2005, p. 9] The above quotation clearly tells that the tallies were the written description of how much of what commodity should an individual taxpayer should pay to the government. Each tally differed from other tallies in their description of taxes. Therefore, tallies could not be used as money as Wray wants us to believe. Besides, "The Exchequer" was not "the great clearing house for government credits and debts", because the Exchequer does not act as clearing house of debts and credits; it only collects taxes and sees whether all taxes are collected or not.

One other thing should be noted here. If tally sticks were issued to only those who were chosen taxpayers, then it is certain that tally sticks were not used by the government for buying goods and services. The fact is that government would buy goods and services by using money that the governments minted. 
Therefore, tally stick (instrument of recording tax) is not the same as money (minted coin). Records of what are to be paid as tax (tallies), therefore, are neither debt instruments (either of the government or of the taxpayers) nor money.

Wray wrongly argues that Hazel-wood tally sticks circulated as means of exchange instead of money. Wray himself accepts that these were records of debt. "Tally sticks were commonly issued for hundreds of years in Western Europe - by Kings but also by others as records of debt" [Wray Nov. 2016, p.4] The way the tally sticks were created also does not prove Wray's assertion that tallies were used as medium of exchange. A. M. Innes, from whom Wray got this idea, writes, "For many centuries, how many we do not know, the principal instrument of commerce was neither the coin nor the private token, but the tally ... a stick of squared hazel-wood, notched in a certain manner to indicate the amount of the purchase or debt. The name of the debtor and the date of the transaction were written on two opposite sides of the stick, which was then split down the middle in such a way that the notches were cut in half, and the name and date appeared on both pieces of the tally. The split was stopped by a cross-cut about an inch from the base of the stick, so that one of the pieces was shorter than the other. One piece, called the 'stock,' was issued to the seller or creditor, while the other, called the 'stub' or 'counter-stock,' was kept by the buyer or debtor. Both halves were thus a complete record of the credit and debt and the debtor was protected by his stub from the fraudulent imitation of or tampering with his tally." [Innes 2004, pp. 32-33] [Quoted in Wray Nov. 2016, p. 4] If "a stick of squared hazel-wood, notched in a certain manner to indicate the amount of the purchase or debt, the name of the debtor and the date of the transaction were written on two opposite sides of the stick, which was then split down the middle in such a way that the notches were cut in half, and the name and date appeared on both pieces of the tally." and "One piece, called the 'stock,' was issued to the seller or creditor, while the other, called the 'stub' or 'counter-stock,' was kept by the buyer or debtor", then this tally cannot be circulated as medium of exchange in trading, because tallies carried different names, different descriptions of debt and cannot be "homogenous" as Wray argues that "The sticks circulated because this debt was "homogenous", unlike the debt redeemed by the cloakroom that takes the form of your specific coat. " [Wray Nov. 2016, p. 4]

There were two types of tallies: One type was issued by the King to his tax-payers mentioning on it the commodities that the tax-payer would pay when he would return the tally to the King's pay-office for matching the commodities with the description on both parts of the tally, a stock and a stub. Tax is certainly not a debt. Tax is a fee for the services that the King gave to his subjects. Another type of tallies was kept by an individual creditor and his debtor so that descriptions of debt could not be tempered with by either the creditor or the debtor. These types of private tallies cannot be exchanged as money in the market as amount of debt and the names of debtor and creditor were written on them.

Wray also accepts that there were two types of tally-sticks when he writes that "Tally sticks were commonly issued ... Kings but also by others as records of debt." Following passages from Wray are the proofs that merchants also used to issue tally-sticks for commercial purposes. These passages are:

"The merchants would keep a running tally for customers, which would be settled later (usually at harvest). For example, tallies of debts for beer consumed would be kept, with the tally settled at harvest by delivery of barley at the official price and measured in the money of account." [Tymoigne \& Wray July 2005, p.8] "This [Hazelwood tally stick] was a 'stick of squared hazel-wood, notched in a certain manner to indicate the amount of the purchase or debt' created when the 'buyer' became a 'debtor' by 
accepting a good or service from the 'seller' who automatically became the 'creditor'. 'The name of the debtor and the date of the transaction were written on two opposite sides of the stick, which was then split down the middle in such a way that the notches were cut in half, and the name and date appeared on both pieces of the tally'. The split was stopped about an inch from the base of the stick so that one piece, the 'stock' was longer than the other, called the 'stub' (also called the 'foil'). The creditor would retain the stock (from which our terms capital and corporate stock derive) while the debtor would take the stub (a term still used as in 'ticket stub') to ensure that the stock was not tampered with. When the debtor retired his debt, the two pieces of the tally would be matched to verify the amount of the debt." [Tymoigne \& Wray 2005 July, p.8] "A merchant holding a number of tally stocks of customers could meet with a merchant holding tally stocks against the first merchant, 'clearing' his tally stub debts by delivery of the customers' stocks. In this way, great 'fairs' were developed to act as 'clearing houses' allowing merchants 'to settle their mutual debts and credits'; the 'greatest of these fairs in England was that of St. Giles in Winchester, while the most famous probably in all Europe were those of Champagne and Brie in France, to which came merchants and bankers from all countries"' [Tymoigne \& Wray July 2005, p. 8].

Therefore, Wray wrongly argues that "the tally sticks circulated" as money. However, it was not the tallies (either issued by the King or issued by any private individual) but the coins that used to be circulated in trading exchanges. Therefore, Kings' tallies were instruments for keeping records of the payable taxes (not IOUs of the Kings) and the merchants' tallies were the IOUs of the buyer merchants (debtor) given to the seller (creditor) merchants. Neither the Kings' tallies nor the merchants' tallies could be used as medium of exchange as Wray tries to make us believe.

\subsection{B. Coins were / are not debt-instruments:}

"To sum up the argument to this point, early money units appear to have been derived from weight units which may have developed from the practice of wergeld. Palaces created the money units to simplify accounting. They also had to establish price lists to value items in the money of account. Initially all of this may have been only to facilitate internal record-keeping, but eventually use of the internal unit of account spread outside the palace. Commercial transactions, rent payments, and fees, fines, and taxes came to be denominated in the money of account. Use of the money of account in private transactions might have derived from debts owed to the palaces. Once a money rent, tax or tribute was levied on a village, and later on individuals, the palace would be able to obtain goods and services by issuing its own money denominated debt in the form of tallies. Coins came much later, but were, like the tallies, evidence of the Crown's debt." [Tymoigne \& Wray July 2005, p. 8]

Wray argues, "Coins ... were, like tallies, evidence of Crown's debt." [Tymoigne \& Wray July 2005, p.7] He writes, "Innes argued that '[t]he coins which [kings] issued were tokens of indebtedness with which they made small payments, such as the daily wages of their soldiers and sailors' (Innes, 1913, p. 399). This explains the relatively large value of the coins - which were not meant to provide a medium of exchange, but rather were evidence of the state's debt to 'soldiers and sailors'. The coins were then nothing more than 'tallies' as described above - evidence of government debt." [Tymoigne \& Wray July 2005, p.10] "Even a gold coin really was a debt of the crown, with the crown determining its nominal value by proclamation and by accepting it in payment of fees, fines and taxes at that denomination." [Wray July 2005, p.13] "we argued that coins were nothing more than tokens of the indebtedness of the Crown, or, later, the government's treasury" [Tymoigne \& Wray July 2005, p. 16] 
"The sovereign spent coins into circulation, then accepted them alongside tallies in tax payment". [Wray Nov. 2016, p. 5] Tallies were records of due-taxes. Therefore, after redemption (payment of taxes in kinds that were described in the tallies), the tallies became useless and were burnt. However, coins were not a debt (Wray mentions that "the coin by itself contained all the evidence of the crown's debt' [Wray Nov. 2016, p.5] of the king; therefore they were not burnt (or destroyed) after tax was paid in coins; they were kept for re-use at a later date. While the tallies were extinguished after tax is paid, coins were not extinguished after taxes were paid in coins. Wray argues that, "When it received coin in tax payments, it held them until an announced redemption day, to exchange for paper notes." [Wray, Nov. 2016, p.7] Wray writes, "Note also that when the King accepted these in tax payments, he was also "redeemed". The tally sticks would be burned (wiping his own debt clean) while coins could be stored for reuse, or melted for re-coining." [Wray Nov. 2016, p. 5]

Wray wrongly argues that coin is a debt-liability of a government when he writes, "What is a coin? It is stamped evidence of the Treasury's debt." [Wray Nov. 2016, p.9] Wray himself writes, "While the US Treasury accounts for coins as "equity", equity is of course on the liability side of the balance sheet." [Wray Nov. 2016, p. 9] However, coin is not a liability (debt) because it is circulated at par its face value and because it is a commodity and commodity cannot be a debt. Government also does not treat coins as its liabilities.

"Coins were evidence of debt that solved the problem of counterfeiting not through splitting a notched stick but rather through the technology of stamping or, later, milling coins. High quality craftwork and then milling the edges made "fraudulent imitation" more difficult. In addition, the use of precious metals (which were more easily monopolized by the sovereign) made counterfeiting more difficult and more expensive. The sovereign spent coins into circulation, then accepted them alongside tallies in tax payment. Coins circulated more freely than tally stocks because the coin by itself contained all the evidence of the crown's debt (in the case of a tally stick one needed both the stock and the stub). In addition to promising to take back coin token debts, the sovereign issuer could also promise to exchange them for foreign currency or for precious metal on demand. This is an additional promise added to the promise to accept the coin in payment of taxes. Even without this additional promise, the tally and coin tokens would circulate because they could be used to redeem tax debts. Note also that when the King accepted these in tax payments, he was also "redeemed". The tally sticks would be burned (wiping his own debt clean) while coins could be stored for reuse, or melted for recoining." [Wray Nov. 2016, p. 5]

"Now, what were coins? As Innes emphasizes, coins were never very important - in spite of all the ink spilled in writing about them. They are essentially metal tallies that can last a long time and still garner interest when discovered centuries after being lost and forgotten." [Wray Nov. 2016, p.4]

"What are the implications of this for our study of money? In our view, coins are mere tokens of the Crown's (or other issuer's) debt, a small proportion of the total 'tally' - the debt issued in payment of the Crown's expenditures.” [Tymoigne \& Wray July 2005, p. 10]

Wray is wrong when he asserts that government issued its IOUs so that taxpayers might pay tax in that government's IOUs. Wray quotes Redish who wrote, "[Kraay (1964)] suggested that governments minted coins to pay mercenaries only in order to create a medium for the payment of taxes' (Redish, 1987, pp. 376-7)". [Tymoigne \& Wray July 2005, P-9] Wray also writes, "The key is debt, and specifically, the ability of the state to impose a tax debt on its subjects; once it has done this, it can choose the form in 
which subjects can 'pay' the tax. While government could in theory require payment in the form of all the goods and services it requires, this would be quite cumbersome. Thus it becomes instead a debtor to obtain what it requires, and issues a token (hazelwood tally or coin) to indicate the amount of its indebtedness; it then accepts its own token in payment to retire tax liabilities. Certainly its tokens can also be used as a medium of exchange (and means of debt settlement among private individuals), but this derives from its ability to impose taxes and its willingness to accept its tokens, and indeed is necessitated by imposition of the tax (if one has a tax liability but is not a creditor of the Crown, one must offer things for sale to obtain the Crown's tokens)." [Tymoigne \& Wray July 2005, p. 10]

Form these two citations above it appears that Wray wants us to believe that the government paid the sellers with government's IOUs and that the taxpayers used those government IOUs to pay their taxes. However, Wray himself contradicts this argument when he asserts that government issued those IUOs to its soldiers who could produce those IOUs to the government's exchequer to get commodities against those IOUs. Wray quotes Cook, "Many believe that the first coins were struck by government, probably by Pheidon of Argos about 630 BC (Cook, 1958, p. 257). Given the large denomination of the early coins and uniform weight (although not uniform purity - which probably could not have been tested at the time), Cook argues that 'coinage was invented to make a large number of uniform payments of considerable value in a portable and durable form, and that the person or authority making the payment was the king of Lydia' (Cook, 1958, p. 261). Further, he suggests 'the purpose of coinage was the payment of mercenaries' (Cook, 1958, p. 257).” [Tymoigne \& Wray July 2005, p. 8-9] This quotation clearly proves that coins were issued not for providing means to taxpayers to pay tax but as a medium of exchange with which people could buy things from the royal treasury or elsewhere. In line with Crawford, Wray argues that those coins (IOUs according to Wray) were used as medium of exchanges when he writes "Crawford has argued that the evidence indicates that use of these early coins as a medium of exchange was an 'accidental consequence of the coinage', and not the reason for it (Crawford, 1970, p. 46)." [Tymoigne \& Wray July 2005, p. 9] This means that coins were used as medium of exchanges.

Coins were paid neither as a 'government's debt' to the sellers from whom government would buy goods nor as an obligation of debt for the taxpayers. But, coins that derived its value from its metal content were issued as medium of exchanges (not just as only a numeraire having no intrinsic value of its own as Wray wants us to believe). Therefore, the instruments of tax payments (generally in-kind payments) and medium of exchange (money) are different and not the same thing as Wray wants to make us accept. Therefore, Wray is wrong when he writes, "Certainly its tokens can also be used as a medium of exchange (and means of debt settlement among private individuals), but this derives from its ability to impose taxes and its willingness to accept its tokens, and indeed is necessitated by imposition of the tax (if one has a tax liability but is not a creditor of the Crown, one must offer things for sale to obtain the Crown's tokens)." [Tymoigne \& Wray July 2005, p.10] Wray is also wrong when he writes, 'money' "are never pure assets but are always debt instruments - IOUs that happen to be stamped on metal" [Tymoigne \& Wray July 2005, p.12] because neither the tally sticks, records of debt or payable tax (Wray tells these were monetary instruments) nor the coins were a debt of either the government or the taxpayers.

Therefore, Wray's assertion that "Similarly, we argued that coins were nothing more than tokens of the indebtedness of the Crown, or, later, the government's treasury ... even though coins were long made of precious metal" [Tymoigne \& Wray July 2005, p. 16] is wrong. 
Wray is also wrong when he argues that "The higher the probability of default by the sovereign on his debts (including coins and tallies), the more desirable was an embodied precious metal to be used in recording those debts. In other words, coins with high precious metal content would be demanded of sovereigns that could not be trusted. This probably explains, at least in part, the attempt to operate gold (or silver) standards during the transition from monarchies to democracies that occurred with the rise of capitalism and the modern monetary production economy. Unfortunately, this relatively brief experiment with gold has misled several generations of policymakers and economists who sought the essence of money in a commodity - precious metals - and ignored the underlying credits and debts." [Tymoigne \& Wray July 2005, pp. 11-12] Here, Wray is misled as he thinks that "The higher the probability of default by the sovereign on his debts" induced the government to make full bodied coins (metallic value is same as the face value). The government did not create coins as its debt but for using the coins for purchasing goods and services. "The higher the probability of default by the sovereign on his debts" did not induce the government to make full bodied coins (metallic value is same as the face value), but because the reduced value of coins would/ could not be sold at par the face value. This was the reason why government was forced to make gold-coins or accept gold standard. This very misunderstanding led Wray to write "Even a gold coin really was a debt of the crown, with the crown determining its nominal value by proclamation and by accepting it in payment of fees, fines and taxes at that denomination." [Tymoigne \& Wray July 2005, sp. 12]

Again, it is not the fact that only the ruling authority could mint money. There were many private money makers who could mint coins and their coins were universally accepted by the people because the coins were traded/ exchanged at par the value of their metal content. Later, the ruling authority made contracts with those money makers to keep uniformity among all types of moneys according to their metal content and value. Wray also accepts that private coinage was in abundance in every country when he writes "After private coinage was forbidden, the right to coin was usually delegated to private masters that worked under contract (Boyer-Xambeu et al., 1994, p. 45)" [Tymoigne \& Wray July 2005, p. 11] and when he quotes Quigguin, "Every local borough could have its local mint (Quigguin, 196?, pp. 57-58)" [Wray July 2005, p. 11]

Coins of the olden days would derive their value from their metal content and if coins were debased or short of weight the ruling authority would take steps punishing those who were guilty of such crimes. Quoting from Quigguin, Wray writes "The coins were rude and clumsy and forgery was easy, and the laws show how common it was in spite of penalties of death, or the loss of the right hand... [Henry I] decided that something must be done and he ordered a roundup of all the money makers in 1125 . A chronicle records that almost all were found guilty of fraud and had their right hands struck off. Clipping was commoner still, and when (down to 1280) the pennies were cut up to make halfpennies and farthings, a little extra clip was simple and profitable. [...] Clipping did not come to an end before the seventeenth century, when coins were machine-made with clear firm edges ... (Quigguin, 196?, pp. 57-58)" [Tymoigne \& Wray July 2005, p.11] Thereafter, Wray himself writes "Thus, kings actively fought any alteration of the intrinsic value of coins which represented an alteration of the homogenous monetary system that they tried to impose. This preoccupation also fueled the belief that intrinsic value determines the value of money." [Tymoigne \& Wray July 2005, p.11] However, Wray is wrong when he argues that "the belief that intrinsic value determines the value of money" and "In our view, coins are mere tokens of the Crown's (or other issuer's) debt, a small proportion of the total 'tally' - the debt issued in payment of the Crown's expenditures." [Tymoigne \& Wray July 2005, p. 9] It is neither a "belief" but is a reality that 
coins derive their value from their metal content, nor is correct that coins are "Crown's debt". The coins issued by the Crown and the coins issued by the private money makers both were made of precious metal and would be accepted at par their metal content; therefore, those coins cannot be treated as debt, because when commodity (metallic coins) were used in exchange of some commodity, the values of both coin and the commodity equals and full and final payment is made leaving neither the seller nor the buyer as debtor.

Wray is inconsistent and his arguments are contradictory. Wray himself accepts that coins were circulated at par their metallic value and that debt would be settled in coins. He writes, "Perhaps coins existed before these tallies (records of debts), and surely the coins were made of precious metals. Perhaps the debts were made convertible to coin, indeed; perhaps such debt contracts were enforceable only in legal tender coin. If this were the case, then the credits and debts merely substituted for coin, and net debts would be settled with coin, which would not be inconsistent with the conventional story according to which barter was replaced by a commodity money (eventually, a precious metal) that evolved into stamped coins with a value regulated by embodied precious metal." [Tymoigne \& Wray July 2005, p. 9] and "Certainly its tokens can also be used as a medium of exchange (and means of debt settlement among private individuals.)" [Tymoigne \& Wray July 2005, p.11] "Part of the appeal of precious metal coins was no doubt the fact that they would have value outside the sovereign's domain." [Tymoigne \& Wray July 2005, p. 11] This is an acceptance on the part of Wray that money is commodity-money made of precious metal and not a monetary instrument that is an IOU or debt instrument (not money).

From the above discussion, it clearly reveals that coins were /are not debts of its issuer (either the King or the private bankers). Coins were/ are commodity-money; it does not derive its value from any proclamation of either the King or the minters (or bankers) but from the value of its content commodity.

\subsection{Paper notes are / were not debt-instruments:}

Wray wrongly argues that "money is the creature of the state" and an IOU of the state. He also writes, "The paper notes are the central bank's liability" [Wray Nov. 2016, p. 8] However, though, in the past, state could create money, other private institutions like banks also could create money. Therefore, money was not the creature of the state only. It was also not an IOU of the state. Nowadays, government does not create paper notes. Wray himself writes, "“Treasury Money" is now mostly coins; in the past treasuries issued notes (and some still do) and while the US Treasury could issue notes, it now only issues coins" [Wray Nov. 2016, p.9]. Only Money Issue Department of the central bank creates paper notes as its liability against the reserve in its asset side. However, the banking sector of the central bank treats paper notes as its assets (not as IOUs of itself) when it gives loan. Therefore, it is also not a debt-instrument or debt either of the central bank or of the government. However, the central bank is liable to give the holder that portion of its reserve that equals to the value of the paper-note. Here, Central bank is not a debtor but acts as safe-keeper of commodity money against which the paper-note has been issued.

Wray also wrongly asserts that government creates and spends its own currency and that tax-payers use the government's currency to redeem their tax-debt. "In theory, the government should accept its central bank notes in tax payment." [Wray Nov. 2016, p.8] and "The first central banks were explicitly created to issue notes to finance government spending, with the notes collected in tax payment." [Wray Nov. 2016, p. 8] However, Wray himself accepts that this is not true when he writes, "For the most part, treasuries no 
longer spend their own currency (coins, notes, tallies) into existence, and taxpayers do not pay taxes with treasury's currency" [Wray Nov. 2016, p.9]

Wray also wrongly argues that "The paper notes were thus "redeemed" in two ways: payment of taxes, or exchanged for coin." [Wray Nov. 2016, p 7] However, tax payment with paper note helps fulfillment of tax, not redemption of itself (paper note). Paper notes cannot be redeemed through payments of debt or taxes (or payment in an exchange or payment in various kinds of fees; what can be redeemed are tax liabilities, debt liabilities and payment liabilities in instant exchanges etc. Paper notes can only be converted to the reserve, against which it is created and paid in exchange of the paper notes. Paper notes can be destroyed only if the reserve of the issuer of the paper note is reduced in same amount, because it is the central bank that creates the paper-notes.

Therefore, contrary to Wray's assertion, paper-note is not debt either of the central bank or of the treasury (government) and cannot be redeemed through payment of tax to the treasury (government).

However, after all these explanations of how money is originated in the light of MMT's own characterization of money used in modern capitalist economy and arguing that it is not commodity money but the debt-instrument (money of account) that was/ is used in exchange of goods and services, the MMT submits that, "To conclude our introduction, we return to our admission that it is not possible to write a definitive history of money.” [Tymoigne \& Wray July 2005, p. 3]

\section{The MMT failed to explain the origin, definition, and function of money because of their misunderstanding (misconceptions) of the following facts:}

\subsection{The MMT's assertion that the government does not need to collect tax and sell bonds is wrong:}

Bell writes, "There is surely no doubt that the proceeds from taxation and bond sales are deposited into accounts held by the U.S. Treasury (either with commercial banks or at the Federal Reserve) and that the government spends by writing checks on Treasury accounts at Reserve banks. Moreover, since funds are transferred from T\&L accounts to the Treasury's account at the Fed in order to cover anticipated shortfalls in these accounts, it certainly looks as though the government uses these proceeds to finance its spending. This apparent interdependence is, undoubtedly, the basis for the treatment of taxation and bond sales as financing operations." [Bell July 1998, p.18] Wray also writes, "So, in the US, the Treasury is required to make deposits to its account at the Fed before it can write checks." [Wray March 2014, p.14] He writes, "The treasury obtains credits through tax receipts and bond sales." [Wray 2019 Sept. p. 5] Wray also writes, "The notion that such taxes "pay for" provision of "public goods" like defense or infrastructure added another layer of justification" [Wray, April 2004, p 3]

\subsection{The MMT's assertion that the government creates money through keystrokes is wrong:}

Wray asserts that government creates and spends its own currency. He asserts, "It [the state] spends its currency into existence. ... A government that issues its own currency can never run out of keystrokes." [Wray 2012 Nov, p. 16] "Government simply creates currency or central bank reserves when it spends? What is this, creation of money out of thin air? Yes, indeed." [Wray, June 2014, p. 7] However, Wray himself accepts that it is the central bank and not the government that issues money. He writes, "For the most part, treasuries no longer spend their own currency (coins, notes, tallies) into existence, and 
taxpayers do not pay taxes with treasury's currency" [Wray Nov. 2016, p.9] and "In theory, the government should accept its central bank notes in tax payment." [Wray Nov. 2016, p.8] and "The first central banks were explicitly created to issue notes to finance government spending, with the notes collected in tax payment." [Wray Nov. 2016, p.8] and, "After the creation of the Fed in 1913, its notes gradually replaced Treasury notes (which are no longer issued). Importantly, the Fed spends reserves when it purchases assets or lends reserves; so it either spends or lends reserves into existence." [Wray 2019 Oct, p.17]

As government can issue only coins it cannot create other forms of money like paper notes and digital currencies and spend through keystrokes and thus create its debt on its own; tax payments by money also does not redeem the government's debt and the money does not extinguish through tax-payments. As government does not create money (as its debt) so it cannot exchange its debt (money) for gold or foreign currency. Therefore, Wray is wrong when he writes, "Affordability is not the problem. A sovereign government can always afford to spend more. Like the American colonies - which authorized more spending financed by paper notes - today's government can spend more using key-stroked entries into balance sheets. This spending increases government's debts, recorded as credits to recipient accounts" [Wray Nov. 2016, p.9] and the fact is that the central banks creates money and injects money into the economy as loan. Government imposes tax and sells bonds and spends the proceeds from these two sources.

\subsection{The central bank's liabilities (money) are not extinguished when they are offered in payment to the state:}

Bell writes, "Federal Reserve notes (and reserves) are booked as liabilities on the Fed's balance sheet and that these liabilities are extinguished/discharged when they are offered in payment to the State." [Bell July 1998, P. 20] However, the MMT is wrong arguing that Central Bank's liabilities extinguish through tax payments in currency to the state. What is said to be the central bank's liability is shown in the Liability side of the Money (Currency) Issue Department of the Central Bank. There, in the Asset side are the reserves against which the currencies are being issued; the currency, thus, issued are shown in the liability side. Such liability (issued money against the reserve) of the central bank can only be extinguished if the reserve of corresponding value is taken out of the Money Issue Department. It is not correct that the liabilities of one institution (the Fed) will be extinguished/ discharged through payment to other institution (the state) when these two institutions are independent of one another. Therefore, Bell is wrong when she argues that money (liability of the central bank) is extinguished when money is paid as taxpayment to the state. Money is extinguished only if it is consumed or no longer used as medium of exchange.

\subsection{Minsky is confused in understanding what money is and what a promise (debt instrument) is:}

Once he differentiates between money and lending when he writes, "Loans represent payments the bank made for business, households and governments in exchange for their promises to make payments to the bank at some future date" [Minsky, 1986, 230] Here, Minsky clearly states that bank makes "payments" against the "promises" of the borrowers. He clearly states that when the borrower presents a check in another bank "For member banks of the Federal Reserve System, the interbank payments lead to deposits shifting from the account of one bank to the account of another at Federal Reserve banks." [Minsky, 1986, pp. 230-1] [Quoted in Wray, March 2014, p. 20] This means the "promises" of the borrowers and 
the "payment" (of the money deposited in the borrowers' account) are different things. Another time Minsky equates money with lending [act of financing] when he writes "Money is unique in that it is created in the act of financing by a bank and is destroyed as the commitments on debt instruments owned by banks are fulfilled. Because money is created and destroyed in the normal course of business". [Minsky 1986, p. 249] Here Minsky is confused because after repayment of what is destroyed is "debt instruments owned by banks" and not the "Money" that is borrowed and repaid. Without fully understanding this ambiguity of Minsky, the MMT made a serious mistake by accepting (or equating) money as debt instruments what it calls 'monetary instrument' or "forward contracts".

\subsection{It is only the Central Bank and not the state (government) that creates Money:}

However, the MMT knows full well that it is the central bank that creates money and that what is argued as state money is in reality the money of the central bank. Bell writes, "Moreover, the Federal Reserve and/or Treasury, as the only agents capable of supplying them [money], must have been the original source of these reserves [money]." [Bell July 1998, p. 5] However, it is only the Federal Reserve Bank and not the Treasury that creates money and "the original source of these reserves [money]."

"There are two real world complications that require some comment. First, most payments in modern economies do not involve use of a government-issued (state, "fiat") currency; indeed, even taxes are almost exclusively paid using (private) bank money. Second, government money is not emitted into the economy solely through treasury purchases. In fact, the central bank supplies most of our currency (paper notes), and it is the proximate supplier of almost all of the bank reserves that are from the perspective of the nonbanking public perfect substitutes for treasury liabilities." [Tymoigne \& Wray July 2005, p.17] "the treasury is not the only source of reserve injections or deductions. Central banks principally provide reserves at the discount window or through open market purchases of sovereign debt, foreign currencies, or gold." [Tymoigne \& Wray July 2005, p.17] "The paper notes are the central bank's liability and the asset of the holder." [Wray Nov. 2016, p.8] "In theory, the government should accept its central bank notes in tax payment" [Wray Nov. 2016, p.8]

"Central Bank Money" is generally comprised of two forms: paper notes and electronic reserves. The paper notes are the central bank's liability and the asset of the holder. ... FR Reserves are keystroke [electronic] entries, representing the Fed's liability and the asset of depositors. Unless you are a bank, a foreign central bank, or some other special entity, you cannot hold these." [Wray Nov. 2016, p. 8] "'Treasury Money" is now mostly coins; in the past treasuries issued notes (and some still do) and while the US Treasury could issue notes, it now only issues coins. What is a coin? It is stamped evidence of the Treasury's debt. While the US Treasury accounts for coins as "equity", equity is of course on the liability side, hardly anyone does that." [Wray, Nov. 2016, p. 9] "For the most part, treasuries no longer spend their own currency (coins, notes, tallies) into existence, and taxpayers do not pay taxes with treasury's currency." [Wray Nov. 2016, p. 9]

Wray is wrong when he writes, "The paper notes are the central bank's liability" [Wray Nov. 2016, p.8] to mean that paper-notes are debts (IOUs) of the central bank. However, paper-note is liability of the central bank in the sense that if the holder of the paper-notes presents to the central bank for conversion, then the central bank is liable to give the holder that portion of its reserve that equals to the value of the paper-note. Here, Central bank is not a debtor but acts as safe-keeper of commodity money against which the paper-note has been issued. 
The Central Bank issues money generally against the government's bond that it keeps as reserve. They treat the government bonds as valued reserve against the fiat money they issues. If the government bond is nothing but mere a scrap of paper, that is no fault of the users/ holders of money. The central bank lends (lending is the only way to inject fiat money into the economy for circulation) the fiat money as if it is backed by some reserve of intrinsic value and charges interest on the fiat money along with repayment of the value of the fiat money. However, it is irrelevant to the users/ holders whether the money is fiat or issued against any reserve of intrinsic value; because in both cases (commodity money or certificate of commodity money and fiat money) the borrowers were/ are bound to pay the interest and repay the principal borrowed amount. Therefore, even if money is created out of nothing or against some scrap of papers (government bonds), the value of money remains the same (as commodity money) to the users/ holders. That money is issued against nothing or something having no intrinsic value is a fraudulence on the part of the central bank who creates money against nothing (or valueless thing) and passes that money to its borrowers as if it is lending the right of some commodity to the borrowers to use for the period of the term of the borrowing. What is the most important issue here is that mainstream economists did not clearly state that money-creation by the central bank out of nothing (or something valueless) is out and out a fraudulence activity on the part of the central bank. Therefore, without accepting this fact (fraudulence of the central bank), the MMT tries to make us believe that money (both commodity money and fiat money) is only a numeraire and derives its value from the proclamation of the creator (the state and the banker) of money and is not commodity.

\subsection{Government cannot burn money that it receives as tax:}

The MMT explains that the government destroys or burns the money that it gets from the proceeds of taxation and bond-sale. They are of the opinion that when government receives money selling bonds or as tax, money becomes extinguished or went out of existence. Bell writes, "in order to 'get its hands on' the proceeds from taxation and bond sales, the government must destroy the money it has collected." [Bell July 1998, p. 21] "Indeed, both taxation and bond sales lead (ultimately) to the destruction of HPM." [Bell July 1998, p. 24] Wray writes, "Note that tax payment redeems both taxpayer and sovereign. Isn't that nice? The sovereign's currency is burned, and the taxpayer can burn her tax bill." [Wray Nov. 2016, p.10] Wray also writes, "Indeed, currency that is redeemed for taxes or in receipt of bond sales is burned, not spent." [Wray Nov. 2016, p. 9] "once received in payment of taxes, coins were usually melted down to verify the gold content and ensure that clipping did not occur. This is effectively what the state does with its tax "receipts"." [Tymoigne and Wray July 2005, p. 18] "Money is created "endogenously" to finance spending. Later, when loans are repaid, the demand deposits as well as the borrower's IOU are debited-money is destroyed." [Fullwiler, Kelton and Wary Jan 2012, p. 2] "Government currency is 'redeemed' when taxes are paid, which simultaneously destroys currency as well as the taxpayer's liability to government." [Wray, 2009 p.10] "The government imposed taxes payable in its own paper notes (its liabilities) or "specie" coin (liabilities of the crown of England). It issued its paper notes in payments by the treasury. When it received its tax revenue in the form of its own paper notes, it burned them. When it received coin in tax payments, it held them until an announced redemption day, to exchange for paper notes." (Wray Nov. 2016, p. 7] Wray writes, "Sovereign currency issuers spend first then tax. And then burn the revenue." [Wray 2019 Oct, p.10] "Government currency is 'redeemed' when taxes are paid, which simultaneously destroys currency as well as the taxpayer's liability to government." [Wray May 2009, p.10] "we essentially taxed private bank notes out of existence." [Randy Wray 28 June -Modern Monetary Theory - The Basics] Tcherneva writes, "Thus, money is a creature of the state and a tax credit for extinguishing this debt." [Tcherneva July 2005, p.2] 
Wray writes, after tax payment is made, "The sovereign's currency is burned, and the taxpayer can burn her tax bill" [Wray Nov. 2016, p.10] However, the MMT is wrong, when it argues that receipts from taxation and bond-sales are destroyed or burnt by the Treasury or the government, because the proceeds from taxation and bond-sales are deposited in the Treasury and government spends out of that deposit. Besides, if government really burns or destroys money and does not use money, then there is no justification of imposing tax and selling bonds at all. The fact is that the government uses the proceeds from taxation and bond sales for purchasing commodities (in kinds and services) and repaying its earlier debts along with accrued interest to the bond-holders.

\subsection{Money and Financial Instrument (according to MMT 'monetary instrument, or forward contract or debt instrument) are not same:}

Minsky, from whom Wray got the idea that there exists no 'money' but 'monetary (debt) instrument', is confused. Once he differentiates between money and lending; in another time, he equates money with lending. He differentiates money with lending when writes, "Loans represent payments [certainly of something, in this case money] the bank made for business, households and governments in exchange for their promises [IOU or monetary instrument or agreement of loan] to make payments [certainly of something, in this case money] to the bank at some future date" ((Minsky, 1986, 230). Minsky clearly states that when a borrower of a bank presents a check in another bank, "For member banks of the Federal Reserve System, the interbank payments lead to deposits shifting from the account of one bank to the account of another at Federal Reserve banks." [Minsky, 1986, pp. 230-1; Quoted in Wray, March 2014 , p. 20] This means that the deposit money (not the lending instrument) is shifted from one bank to the other bank and only the lending instrument is destroyed but the money is transferred and not destroyed. Another time, Minsky equates money with lending [act of financing] when he writes "Money is unique in that it is created in the act of financing by a bank and is destroyed as the commitments on debt instruments owned by banks are fulfilled. Because money is created and destroyed in the normal course of business". [Minsky 1986, p. 249] Form these two quotations it clearly appears that the agreement of loan (or debt), not money, is destroyed when the loan is repaid with the money; and money (that has been lent) is returned to the bank. Wray could not understand this ambiguity of Minsky. Therefore, he, without identifying the contradiction in Minsky, made serious mistake by accepting (or equating) money with debt instrument what he calls 'monetary instrument'.

\subsection{It is not true that in the capitalist economy "the accumulation of money [that is characterized by the MMT as only "monetary instrument" or "forward contract"] is the driving force of economic decisions". [Tymoigne and Wray, July 2005, p. 5]}

Wray writes, "The monetary production economy ... is dominated by a complex web of financial relations that were characterized by Minsky as "money now for money later" propositions. (Minsky 1986 p. 228) ... the money of account and those credit-debt relations are the key institutional relations of the capitalist economy." [Wray March 2014, p.11] Wray writes, "The store of value function could also be important, for one stores wealth in the form of others' debts." [Tymoigne and Wray July 2005, p.2] "Thus, the purpose of production in a "market" economy is to accumulate money-denominated units of the social measure of wealth. Accumulation of money-denominated assets becomes the universally recognized path to wealth" [Wray May 2012, p. 20] However, it is not true that businessmen want to acquire only more IOUs (money of account) and not wealth. To acquire more "money of account", one 
should lend more and more. However, businessmen will not just go on lending without redeeming the "money of accounts" in the form of commodities. Therefore, Wray's argument is wrong. People exchange their money or commodity to get something that they can consume and not merely to acquire a credit (debt) instrument that the MMT calls as "money dominated assets".

\subsection{Debt or forward contract is also a form of barter exchange:}

Ingham writes, "[M]edia of exchange cannot evolve spontaneously through repeated barter exchanges into monetary systems in which debts are expressed in units of abstract value and settled by means of final payment/settlement of debts that represent quantities of the same value." [Ingham 2013b, p. 126; Quoted in Wray March 2014, p. 23 -26] Here, Ingham is misled. He understands barter exchange with commodity (commodity may take the form of money if it is universally accepted as the means of final and full payment) and exchange through deferred payments (using the debt instruments) are different. However, both exchange of commodities and deferred exchanges are the two forms of barter. In both cases full and final payment is made only by exchanging commodity or certificate of commodity (that is token money; it may be paper money or e-money or some base metal). In an instant (or direct exchange) exchange, commodities are exchanged instantly; in a deferred exchange, the debtor (who cannot pay any commodity instantly) makes payment at a later date or time. Only difference is that the creditor may or may not ask or charge for some extra commodity (or commodity money or a token or representative money and not a debt instrument) as interest for the period of delayed payment. Besides, if exchanges are not made in commodities (commodity may be commodity money), then what is being lent or borrowed and with what the final payment will be made. Both types of exchanges existed side by side in the past. In India, both the ruling authority and the private bankers used to issue only commodity-money until the mid-19th century when the European bankers introduced paper money (token money). People used to trade with commodity money; and, at the same time used to give or take loans against credit or debt instruments. Therefore, it is not correct that only the credit (debt) instruments were and are used in any exchange as the MMT wants us to believe. Credit (debt) instruments cannot be redeemed if there were no commodity money to ultimately redeem them. What do we credit (debt)? It is the commodity or commodity-money. And this credit (debt) must be redeemed by the payment of either commodity or commodity-money. Credit (debt) cannot take place if there were no commodity (commodity-money) at all.

\subsection{Repayment of bank loans and payment of tax are not the same:}

Ingham writes, "In monetary systems, it is the obligation of the issuer of money - bank, treasury, etc - to promise to accept that which it has issued as the final settlement of any debt owed to it." [Ingham 2013b p. 128; Quoted in Wray March 2014, p. 23 -26] Wray writes, "Money is created "endogenously" to finance spending. Later, when loans repaid, the demand deposit as well as the borrower's IOU are debited-money is destroyed." [Fullwiler, Kelton and Wary, Jan 2012, p. 2] However, it is wrong to equate tax payments with loan repayment. Government does not issue money. Government spends money to buy goods and services. It does not give loan. Therefore, tax payment is not like loan repayment. Tax is paid against the services we get from the government. Though banks issue money it does not buy. Bank lends. The borrower repays the loan with interest. Therefore, payment of tax is not same as in the case of loan repayment. 


\subsection{Wray's arguments regarding gold-standard are full of contradictions:}

Explaining "Why full employment policy requires fiat money" Wray wrote that "If the currency issued by the government were "backed by" and made convertible into a precious metal (or anything else) of relatively fixed supply, then the ELR proposal becomes impossible to implement during times of crisis" [Wray, Nov 1997, p 32] and "fear of a run on the dollar led the government to finally abandon convertibility in 1971. Since that date, gold reserves could never again constrain deficit spending. There is no longer any major (real, as opposed to perceived) barrier to implementation of a full employment policy." [Wray, Nov 1997, p 35]

However, the government, by no way, is the beneficiary of the abandonment of gold standard. The government did not get freedom from converting money into gold or something precious metal; it is the central bank that has got freedom from converting money into gold. Wray himself accepts it. Quoting from Ruml, Wray writes, "Final freedom from the domestic money market exists for every sovereign national state where there exists an institution which functions in the manner of a modern central bank, and whose currency is not convertible into gold or into some other commodity." [Wray Jan. 2018, P 7]

However, later, Wray realized that if he accepts that there was a gold-standard in the past then he must accept that money was commodity-money in nature. But, he wants to establish that money was "financial instrument" for "forward contracts" and never was a commodity. So, he rejected his earlier stand and, now, asserts that, "Typically, the money-thing issued by the authorities was not gold-money nor was there any promise to convert the money-thing to gold (or any other valuable commodity)." [Wray, Dec. 2001, p 10]

Wray also wants to establish that government creates money when it spends. As, according to him, there was and is no gold standard, so it will be wrong to argue that the government creates money out of nothing as "fiat money". Wray wrote that, "I [Wray] confusingly called fiat money". [Wray, Dec. 2001, p 1] Then, he writes, "In my view, a system based on a commodity money is not a "money economy" [Wray, Dec. 2001, p 4] He views money as "tax-based chartalist" money" [Wray, Dec. 2001, p 5] "What do we mean by TDM [Taxes Drive Money]? We mean that "state" (or any other authority able to impose an obligation - whether that authority is autocratic, democratic, or divine) imposes an obligation in the form of a generalized, social unit of account - a money - used for measuring the obligation." [Wray, Dec. 2001, p 8] and "When government issues HPM [High Powered Money] to buy something, it is 'liable' only to accept that same HPM in epicentric (i.e., tax) payments to the state." [Wray, Dec. 2001, p 12] Wray, no more, argues that "Part of the reason for the reluctance to deficit spend was the convertible nature of the currency." [Wray, Nov 1997, p 34]

\subsection{MMT's "Monetary instrument" and Money are different things:}

The MMT is wrong when it writes "Monetary instruments are never commodities; rather, they are always debts, IOUs ... even "money things" are always debts - whether they happen to take a physical form such as a gold coin or green paper note." [Tymoigne and Wray July 2005, p. 19] and "The phrase "debt-free money" is based on a misunderstanding. ... They are all IOUs. They are either spent or lent into existence. Their issuers must accept them in payment." [Wray June 2014, p-7] 
However, the issuer of money promises only to convert the money into the reserve that it keeps, as warehouse safe-keeper, as assets in its Money Issue Department. If Money would be an IOU of its issuer, then the issuer should pay interest to the holders of that money. Whether money is commodity money or is created out of nothing, in both cases, the borrowers remain liable to repay the principal and the interest on it. "To consider that debt is money, it requires the answer what is to borrowed or lent; the answer is money." [Adak, Dec. 2016c, p.7] Therefore, debt is not money. The borrowers borrow money against their IOUs. "The IOUs are in the form of agreement that cannot function as universal equivalent and are not accepted by any person outside the trusted ones." [Adak, Dec. 2016b, pp.6-7] Money is not IOU of the Central bank. However, "Whenever the CB needs to create money it keeps matching reserve of government bonds [that have no intrinsic value] in its money issue department. It is an act of fraudulency". [Adak, April 2017b, p.11]

\subsection{Money is not just a numeraire; it bears a value or represents the value of a commodity against which it is created:}

Wray writes, "We thus conclude this story about the origins and nature of money. ... Monetary instruments are never commodities, rather, they are always debts, IOUs, denominated in the socially recognized unit of account. Some of these monetary instruments circulate as "money things" among third parties, but even "money things" are always debts - whether they happen to take a physical form such as a gold coin or green paper note." [Tymoigne \& Wray July 2005, p. 19] Wray also writes, "The money of account is chosen by the sovereign and used to denominate debts, prices, and other nominal values. It is the Dollar in the US. It is like the inch, the pound, the meter, the kilogram, the acre or the hectare-a unit of measure. Mat [Mat Forstater] puts it this way: the sovereign can no more run out of "money" than it can run out of "acres" or "inches" or "pounds". We can run out of land, but we cannot run out of acres. We can run out of trees but we cannot run out of the linear feet we use to measure them. You cannot run out of a unit of measure! The "dollar" is the measuring unit in which we keep our monetary records. We cannot run out." [17 June 2014, Wray, Tax Bads, Not Goods, p. 1] However, money (what the MMT terms as "money of account") is not just a number. A 10 dollar note represents relative unit values of every commodity. It represents that a portion of a commodity, value of which is equal to the face value of the dollar. With a 10 dollar note, one can buy 10 sandwiches or 5 oranges or 1 cake. Therefore, it is not value free; it represents this or that commodity (though not a single or specific commodity). Initially, it represents that commodity against which it is made or with which it is exchanged. Then it is used as a medium of exchange on the basis of the value of the commodity which is being exchanged and whose value equals to its face value. Every time it is exchanged, it represents the commodity against which it is exchanged.

\subsection{Money is an instrument with which full and final payment is made:}

Anything (material or abstract) that has a direct or indirect bearing on the human race is wealth. Commodity is that wealth that has been marketed for sale or purchase. Money is that commodity which is universally accepted as medium of exchange. Money is that commodity with which full and final payment is made. Financial instruments cannot be used for full and final payment. Financial instruments are extinguished only when the debt (against which the financial instruments are created) is fully and finally paid with money. 


\subsection{MMT's assertion that the Government need not repay its debt is misleading:}

Wray asserts that "the sovereign never needs to pay back (retire) its debt" [Wray 2019 Sept. p. 3] and "government debt does not need to be "repaid" " [Wray 2019 Sept. p. 14] However, Wray himself argues that "government debt is financial wealth — so leaving debts to our grandkids is a source of wealth, not a burden." [Wray 2019 Sept. p. 14] He also argues that, "Government interest payments on bonds held outside the central bank are optional. But whatever interest the government decides it will pay, it will always be able to "afford" to pay it. ... Even if the interest rate were above the growth rate, the government can make those payments, as a government never needs to repay its "debt." [Wray 2019 Sept. p. 8]

However, even though the bondholders may treat bonds as their wealth, the government will have to increase tax to redeem its debt and accrued interest to the bond holders. With the increase in debt over the years, the amount of repayable amount of money will also increase every year. A time will come when the tax receipt will be less than even the amount of the repayable interest on the debt. Wray himself is aware of this fact. He writes, "while there is no affordability constraint, sovereign spending faces real resource constraints and if it spends too much this can cause inflation and possibly affect exchange rates." [Wray 2019 Sept. p. 3] "Further, increasing government spending can mean that too few real resources are left for the private sector's use." [Wray 2019 Sept. p. 8]

\subsection{Deficit ceiling is not "self-imposed constraints" of the Treasury:}

Bell wishes that "Barring self-imposed constraints, the Treasury could manufacture all of its spending balances by selling bonds directly to the Federal Reserve." [Bell July 1998, P 19]. However, the wish of Bell will never be fulfilled, because by selling bonds to the Federal Reserve, government will be indebted to the Fed for the sum of money that it will borrow from the Fed and to make provisions for paying that debt with accrued interest, the government either will need to take more loans from the Fed or to increase taxes. Thus, the constraints is not "self-imposed", it is the bottleneck that is a reality in the economy (fiscal policy) as it is functioning now. Without wishing that government may borrow as much as it wishes from the Fed, the MMT should find other ways and means so that government does not need to borrow at all.

\subsection{The MMT is wrong in asserting that there was no barter system in the past:}

The MMT writes, "The orthodox explanation of the origins of money is based on the existence of an economy based on barter exchange in formal markets (the fairground barter) which predates the introduction of "money." But this is neither historically accurate, nor is it coherent". [Wray May 2012, p.9] According to the MMT, "The origins of money are not to be found, then, in a hypothesized exchange society based on barter." [Wray May 2012, p.15] However, barter economy was not a hypothesis. The barter system in its full form existed through the caste-based distribution of occupation on a hereditary basis in India till the mid-20th century.

As the ancient people could not find any acceptable medium of exchange; and as gold or any precious metal which might be accepted as a medium of exchange were not found in sufficient quantity or was not always available everywhere; so they could not avoid barter system. The solution, which they found for smooth exchange, was assigning each family or group of families the duty of producing and providing one of the commodities or services to all member-families of the settlement. Thus, the production and the 
distribution of all the commodities and services, which the community as a whole needed were accomplished or achieved. No family remained outside this arrangement. Thus, an occupation was secured to each family and there remained no problem of exchange through the barter system. 'Caste' is the identification of profession to which a family or a group of families are hereditarily tied.

Population was divided into four 'varna's according to the characteristics of their occupations. Those four 'varna's are 'brahmana's (Wise men like priests and teachers), 'Kshatriya's (warriors who defend the country and protects people from any encroachment), 'Vaishya's (who produce wealth, grow food, manufacture article), and 'Sudra's (menial servicemen). Each 'Varna' was sub-divided in different 'Jati's according to their specific occupations. Who presses oil, is called 'Teli', who washes clothes, is called 'Dhobi'; who makes ironware is called 'Karmakar'; who makes earthenware is called 'Kumbhakar' etc. This caste system worked through a hereditary "Kamin-Jajman" relationship between the providers of goods and services called 'Kamin's and the receivers of goods and services called 'Jajman's. Thus, every 'Jati' has its own hereditary occupation. All these 'Jati's are interdependent on one another and are 'Kameen' or 'Jajman' in turns. Even the king (ruling class) acts both as Kameen and Jajman. The King, as Kameen, serves the people by protecting them from outside aggression and from internal violence and acts as Jajman of his subjects when he receives tax from his subjects.

Except the agriculturists who harvest their produce seasonally, all other jatis used to serve or give articles to other jatis throughout the year regularly. Agriculturists used to give their due to their Kameens after they harvested their crops.

However, some aborigine tribes like Kol, Bhil, Santal, Munda etc who lived in deep forests or mountains did not accept this caste system and they still remained outside this caste framework. They live on the forest products and did not need occupation-based production and distribution system.

The ancient lawgivers codified this distribution of occupations as hereditary and linked it with the wishes and actions of the God i.e. Brahma, the creator of mankind, so that even after any disruption like natural calamities or warfare, the people could stick to their occupations assigned to them. Codification of the caste system as hereditary solved the problem of exchanging commodities through barter permanently. People accepted this system willingly. Manu, one of the ancient lawgivers, codified this caste-system in his 'Manusmriti'. [G. Buhlar. 1886] William Henricks Wiser found that even in 1930s this caste system was prevalent almost intact in the Indian society. [Wiser, William Henricks 1936] The present writer has presented a paper titled "Caste system in India: A Unique wisdom to resolve problems like barter, distribution and unemployment" at an international conference at Bangkok. [Adak Dec. 2016a]

\section{Conclusion: An Assessment of Modern Money Theory:}

From the above discussion it is conclusively proved that the earlier money-theories, on which the MMT is based have contradictions misconceptions in analyzing what money really is, are not based on reality. As MMT is grounded on those wrong theoretical arguments, so, their explanations and conclusions about money, monetary and fiscal theories are also not rational and suffer from inconsistencies. In this section, I will discuss the following reasons for why and how the MMT is misguided.

MMT wants that all unemployed should and must be employed by the state as private sector cannot ensure full employment in the present capitalist system. To enable the government to spend as much as it needs for achieving full employment, MMT needs a theory according to which the government will not face any financial constraints. This purpose will be fulfilled the best if it can be established that the 
government can create money to be able to spend as much as it needs. However, in constructing such a theory, MMT needs to declare that money is not a commodity. Because if money is pegged to any commodity then the government will not be able to create as much money as it needs, as the government will not be able to acquire that much amount of commodity. Therefore, the MMT invented a theory that the government creates money out of nothing or from thin air. However, MMT faced a real difficulty in establishing this theory; that is, if government can create money out of nothing then why the government must impose tax. The MMT knows very well that in reality government depends on proceeds from tax and bond-sale. MMT needs a theory to combine both the new theory that government creates money out of nothing and the reality that government depends on tax and borrowing. Therefore, MMT invented another theory that government creates money out of nothing as debt and that debt must be redeemed by payment of tax to the government. Why government must levy tax; the MMT invents another theory that to make government's money acceptable and to reduce inflation, government should impose tax. Thus, the MMT tries to establish a theory that money is nothing but debt (of the government) and that the debtmoney is nothing but a record of the amount of debts and credits. The MMT did not bother to ask or clarify debts or credits of what, they simply by-passed this question by stating the money is merely a numeraire or a debt (monetary/ financial instrument) instrument on which debts and credits are recorded. To establish their theory that money is nothing but a debt instrument, they invented or imposed a theory that in modern capitalist economy, exchanges are being done using only debt-money or financial instruments. Again, to establish this theory on the historical foundation, the MMT invented or claimed that never there was any commodity-money, even if money was full-bodied gold or silver coin. Thus, MMT's explanation of money and its origin is biased in the sense that MMT did not try unearthing/ unfolding how and why money has been evolved. They admit that they want to explain money and its origin according to what they formulated as essential characters of money, i.e., money is a debt (financial instrument) having only records of debts \& credits and no intrinsic value of its own.

MMT argues that it is impossible to trace the history of the origin of money. "To be sure, the history of money is "lost in the mists of time," as money's invention probably pre-dates writing. Further, the history of money is contentious."'[Wray May 2012, p.3] Besides, MMT argues that they are not clear how they will identify a thing as money. MMT writes, "It has long been speculated that money predates writing because the earliest examples of writing appear to be records of monetary debts - hence, we are not likely to uncover written records of money's "discovery". Further, it is not clear what we want to identify as money." [Tymoigne \& Wray July 2005, p.1] The MMT does not agree to the Orthodox economists' view that money is commodity that is used as medium of exchange.

"The orthodox economist views our economy as a more-or-less free market economy in which ... money is used primarily to facilitate exchange of real goods, undertaken by self interested maximizes for personal gain." [Wray May 2012, p.5] However, the MMT discarded this Orthodox view of money and argued that "The orthodox explanation of the origins of money is based on the existence of an economy based on barter exchange in formal markets (the fairground barter) which predates the introduction of "money". But this is neither historically accurate, nor is it coherent. The institutional prerequisites to the development of market exchange include the existence of private, alienable property, recognition of individual responsibility, self-interested behavior, and forward-looking production. Yet, the historical examples of barter exchange used to justify the traditional approach rarely show any of these characteristics. This paper will argue first that primitive "exchange" or "barter" did not lead to the development of markets; second, that money did not develop out of primitive "exchange;" third, that both 
"fiat money" and "credit money" predated coined "commodity money;" and fourth, that the quantity of credit money has never been constrained by the quantity of central bank liabilities, as in the "multiplier" story." [Wray May 2012, p.9]

As the Orthodox view cannot explain the origin of money fully and as the MMT itself cannot explain the origin of money because "To be sure, the history of money is "lost in the mists of time"", so, the MMT argues that it will be judicious to search the origin of money in the light of the nature and function of money in the modern capitalist system. The MMT writes, "There is probably no single source for the institution of modern capitalist economies that we call "money"" [Tymoigne \& Wray July 2005, p.1] "More importantly, trying to uncover "the" origins of money is almost certainly an impossible or at least misguided endeavor unless it is placed within the context of a theoretical framework." [Tymoigne \& Wray July 2005, p.1] The MMT writes, "Given the embedded nature of economic phenomenon in prior societies, an understanding of what money is and what it does in capitalist societies is essential to this approach. This can then be contrasted with the functioning of pre-capitalist societies in order to allow identification of which types of pre-capitalist societies would use money and what money would be used for in these societies. This understanding is essential for informed speculation on the origins of money." [Wray May 2012, p.1 \& 8] "The comparative approach used by heterodox economists begins with an understanding of the role money plays in capitalist economies". [Wray May 2012, p.2] "If one can develop an understanding of economic phenomena of a capitalist economy, one may use the comparative method to develop an understanding of pre-capitalist economies and improve one's understanding of the capitalist economy." [Wray May 2012, p.7]

The MMT explains that modern capitalist economy does not use money for exchange of goods and services. MMT writes, "An identical economy [capitalist economy] is then hypothesized that does not use money. These are then "compared" to discover why money was invented." [Wray May 2012, p.8] The MMT explains how "money should be defined. In this [MMT] approach, money cannot be identified by its peculiar individual physical "characteristics" (malleable, durable, transportable), nor by its functions (transactions medium, means of payment, etc.). Rather, money is defined with respect to the operation of the economy as a whole. Money is identified as a unit of account; it becomes the social measure of value in all monetary economies. It is an abstract "measuring unit."” [Wray May 2012, p.8]

Thus, the MMT tries to establish that for an exchange, what is used is not commodity-money but the debt-instrument (IOU or financial instrument, MMT calls it as 'monetary instrument' also) in the capitalist economy and that purpose of any economic activity is only to obtain and amass credits (debt dominated assets or financial instruments or IOUs of others) The MMT writes, "In a monetary economy, the purpose of production is to obtain money-denominated assets; this can be contrasted with a "barter" economy." [Wray May 2012, p.8] The MMT argues that what is used in modern capitalist system is not commodity-money but mere a number (numeraire) having no intrinsic value and only a promissory note (IOU or financial or monetary instrument). They distinguish these two things thus: "It is necessary to distinguish between money as a measuring unit and those assets denominated in the money of account. Thus, bank deposits are not money, but are denominated in the social unit of account - that is, money (the dollar in the US). Similarly, it is necessary to distinguish between money and those various functions performed by assets denominated in the unit of account: money is not what money does." [Wray May 2012, p.9] They clarify their understanding of modern money thus: "Some money-denominated assets function as media of exchange or means of payment. While these functions are typically fulfilled by 
certain money-denominated assets, this does not make any particular asset that so functions money." [Wray May 2012, p.9]

Thus, with the help of their self concocted theory of money of capitalist system, the MMT begins to explain the history of the origin of money. As the MMT concludes that money is nothing but debtinstrument, so they begin to assert that money originated only as debt-instrument (forward contracts) in the primitive days and this debt-instrument nature of money is continued to modern capitalist system. The MMT writes, "Thus, the earliest form of economic exchange produced forward contracts which, in the extreme, took the form of debt bondage in which the "debtor initially rendered himself in the power of the creditor as a debt serf and the creditor at any time during the credit term could call upon the debtor-even up to his extermination"”' [Wray May 2012, p.13] Therefore, according to MMT, ““"The origins of money are not to be found, then, in a hypothesized exchange society based on barter. Instead, money develops as a unit of account, or, as the terms in which debts are written: "A money of account comes into existence along with debts... Money proper in the full sense of the term can only exist in relation to a money of account." (Keynes 1971, p. 3) When private loans are made, the lender gives up private property in exchange for an IOU issued by the debtor, which represents a forward contract. This private contract must include an interest premium. ... Thus, all forward contracts involve "wheat now for more wheat later" propositions, which are monetary propositions, with money serving as a unit of account." [Wray May 2012, p.15] Thus, the MMT concludes that the history of evolution of money (that was used in the past and is used at present) should be explained in the light of the role that the modern money plays in the capitalist economy as merely an instrument of loan or forward contract, i.e., "money now for more money later". The MMT writes, "By distinguishing money from the various functions it performs, we may conclude that primitive, pre-private property economies did not use money. It is thus an inappropriate use of the comparative method to try to find objects that fulfill "money-like" functions in tribal societies and then label these "money." Rather, our understanding of the role money plays in capitalist economies enables us to use the comparative methodology to identify the contrasts between monetized economies and those based on communal, reciprocal relations - the latter do not use money, although we may find objects that superficially appear to fulfill some of the functions we now associate with assets denominated in the money of account." [Wray May 2012, p.16] "“Thus, capitalist production always involves "money now, for more money later." The market, then, "is not a place of barter...but a place for earning the means of settling debts, i.e. money" (Heinsohn and Steiger 1989, p. 193)." [Wray May 2012, p.16] "While many economists (and historians and anthropologists) would prefer to trace the evolution of the money used as a medium of exchange, our primary interest is in the unit of account function of money. Our alternative history will locate the origin of money in credit and debt relations, with the unit of account emphasized as the numéraire in which credits and debts are measured. The store of value function could also be important, for one stores wealth in the form of others' debts. On the other hand, the medium of exchange function and the market are de-emphasized with regard to money's origins; indeed, credits and debits can exist without markets and without a medium of exchange." [Tymoigne and Wray July 2005, p.2]

Thus, the MMT clearly confesses that whatever may be the history of origin of money, they only wants to define money as nothing but debts or forward contracts. They cannot accept that money originated as commodity money, because, then their purpose of establishing money as debt-instrument will not be fulfilled. The MMT argues that means of exchange was/ is always a unit of account (only number/ unit of debt) and not commodity-money, even if this unit of account may take the form of a commodity. It is clear that the MMT is not interested in uncovering the origin, definition and history of money. As the 
MMT thinks that "full employment policy requires fiat money" [Wray, Nov. 1997, p. 32] so they arbitrarily asserts that the capitalist system use only instruments of forward contracts (not money) in business transactions. Then they began to assert that, "In summary, money first existed as a unit of account. ... The first standardized money of account was wheat, but it was subsequently replaced by barley. Money, recorded as a debt denominated in a unit of account, would be created as part of a forward debt contract. Money acting as a medium of exchange or means of payment would take a physical form (wheat or barley, and later, clay tablets, wooden tally sticks, metal coins, or paper IOUs), denominated in terms of the idealized money of account. Because production in a market system is always monetary production, its purpose is to realize production in money form. Thus, the purpose of production in a "market" economy [was and] is to accumulate money-denominated units of the social measure of wealth. Accumulation of money-denominated assets becomes the universally recognized path to wealth; the money of account becomes the social unit of value." [Wray May 2012, p.20]

Thus, MMT reduced money (that was/ is nothing but commodity-money or token or certificate of commodity) to mere written record of debts or credits in number of units having no intrinsic value, i.e., a numeraire only. However, money was/ is not a debt or credit; exchanging money with some commodity leaves neither the seller nor the borrower as lender or borrower; the exchange becomes full and final as both that were/ are being exchanged are commodities of equal value. Therefore, money was/ is neither only a number ("unit of account" or "money of account") and nor a record of forward contract or debt but commodity-money or certificate of commodity.

It also becomes clear that the theories of MMT (credit theory of money, state theory of money, hierarchy of money, consolidation theory, functional finance, theories regarding tax and bonds, and government as the employer of last resort etc) that have been discussed earlier were impractical, contradictory and fantasies. Therefore, MMT, though cherished to provide an alternative theory of money, has miserably failed to provide a rational and reasonable alternative theory of money or of the evolution of money and monetary system. They failed because they characterized money in their own way and then began to explain the origin of money in the light of their own understanding of money.

Wray writes, "We need a new meme for money. ... It would focus on the positive role played by the state not only in the creation and evolution of money but also in ensuring social control over money." [Wray 2012 Nov, p. 4] He claims that "MMT provides a correct description of the operation of modern monetary systems, so it makes sense to base our alternative meme on the correct approach to money. However, this contribution is not so much concerned with a correct theory, but rather with developing a progressive meme for money - a story of money's origins, nature, functions, and operations that can serve as an alternative to the orthodox story" [Wray 2012 Nov, p. 5] The present author has shown in one of his previous paper that, "Without framing a new definition of money, Wray vainly wants to create a meme for money that is utterly unrealistic and certainly misleading and confounding. Wray needs "a new meme for money". However, at present, he cannot offer the right framing or the right meme for money. $\mathrm{He}$ states, "I don't pretend to have found the right one(s). But I hope to have contributed to the initiation of a discussion". [Wray 2012 Nov, p. 21] Wray disastrously failed to create an alternative "Meme for Money". His 'meme's will certainly create more problems for those who will try to formulate the rational and practical definition of money." [Adak, Oct. 2016a, pp. 16-17] According to the MMT, money is monetary instrument that is an IOU and used only for forward contract and not used for a settlement of full and final 
payment. It is a deception on the part of the MMT economists who swear that they will find the real definition of money. They willfully distorted the definition and origin of money.

\section{Suggestion:}

The most important aim of economics is to see that production and distribution systems reach the optimum level. This can be done the best if all unemployed get employment so that they can earn sufficiently for a decent living. However, all cannot be employed either by the private sector because of NAIRU effect or by the government due to 'deficit ceiling' constraints in financing the government budget. Private sector gets funds initially from the central bank as loan and the government gets funds from private sector through tax and bond-sale. The primary constraint of sufficient supply of money to the private sector is that money comes into existence in the economy as loan from the central bank. The principal loan has to be repaid with accrued interest. This system of loan repayment needs more amount of money than the principal amount of loan. Therefore, it is mandatory to find a theory to make money's origin as debt-free. Without realizing the problem of debt nature of money, the MMT asserts that "“'debtfree money" is based on a misunderstanding" [Wray June 2014, p-7] implying that money must be debt. The MMT does not realize that it is the "debt-money" that is the systemic defect of monetary system and is the primary cause of almost all economic ills and that to achieve sustainable economic growth money must be originated as "debt-free".

However, the problem is not who issues the money, whether it is a private banker, the central bank or the government. The problem is also not whether money is a commodity or debt-money (fiat money). The problem is that money enters the economy as debt from its issuer. And it is the real problem.

Let me explain my point briefly. Only the central bank creates money. Money can enter into the economy only when the CB injects money as a loan. This system of injecting money as loans irrecoverably affects the economy.

Think of a zero-hour when no money is there in a nation. As only the Central Bank (CB) has the sole authority to create and inject money in the economy of a nation, so the money will be available only when the CB will lend money. The CB gives loans only to the Public Sector Banks (PSBs) or Commercial Banks.

Consider that the total amount of money the CB injects as a loan to the PSBs is $\$ 100$ million. The PSBs give the whole amount of $\$ 100$ million only to the commodity-producing companies. The producing companies spend the whole amount of $\$ 100$ million only for producing commodities (without spending on infrastructures, consruction, etc). Then the cost price of the total products is $\$ 100$ million.

Consider that the CB charges 10\% interest on the loan from the PSBs. The PSBs will add say 5\% interest for handling and other charges. Consider that producing companies will not make any profit. Even then the total charges will amount to $(10+5) \%$ of $\$ 100$ million i.e. $\$ 15$ million. Thus, the minimum aggregate sale price of all the products $/$ commodities will be $\$ 100$ million $+\$ 15$ million $=\$ 115$ million .

The money spent by the producing companies has gone to the hands of the people. Therefore, the total amount of money in the hands of the people will be $\$ 100$ million. If, for argument's sake, we consider that the people spend all the money for buying those commodities which are produced by these producing 
companies only, then commodities worth $\$ 100$ million will be sold and commodities worth $\$ 15$ million will remain unsold.

However, people who got this $\$ 100$ million will not spend money to buy only those commodities that are produced by those companies. They will buy goods and services like vegetables, meat, household labor, fruit, fish for the production of which such financing is not necessary Thus, a portion of the money will be spent to buy other commodities that have not been produced using the money that the CB has lent. A portion will be paid as tax to the government. A portion of the money will be saved in the banks or government bonds. A portion will remain in the wallets of the people. In that case, the number of unsold commodities of the producing companies who took loans from the PSBs will worth more than \$15 million.

Thus, the Central Bank's practice/mode of injecting money into the economy as loan through the PSBs will create the following problems. (1) The interest that is to be paid will increase the cost price /saleprice. It will increase Consumer Price Index. (2) Commodities will remain unsold and it causes the recession. (3) As products remain unsold (in this case at least $15 \%$ or more) production units suffer losses. (4) The production unit may reduce their production or may declare closure. (5) It may decide to layoff to reduce its loss. (6) The production units will fail to repay their loan (in this case 15\%) to the PSBs. (6) It will cause NPA (Non-Performing Assets) of the PSBs to increase. (6) The PSBs will declare themselves insolvent or bankrupt. (7) Employment will be reduced, as the corporate sector will reduce the number of their employees. And, so on. (8) After repayment of the principal amount of $\$ 100$ million (if it can be done at all) to the $\mathrm{CB}$, there will be no money left in the economy. No economic activity will be possible. Acute recession or the collapse of the economy will take place. Therefore, to keep the economy running the $\mathrm{CB}$ will have to inject more money into the economy as loan. This will burden the economy more and more with un-repaid loans. Loans will be increased with the progress of time. However, the CB can inject money into the economy only if anybody approaches the $\mathrm{CB}$ for borrowing. The $\mathrm{CB}$ will not extend the loan again to a defaulting borrower. It will extend loan to a borrower that has creditworthiness. However, the aggregate loan of the non-government sectors will keep on increasing. "Therefore, the basic systemic defects with the origin of money and with the process of injecting money into the economy should be corrected. Only then, the economy will be free from various maladies [like the occasional boom-bust cycle and recession or depressions]." [Adak, Oct. 2016, p. 2]

Therefore, economists should think of abandoning the present practice of lending money to the economy as debt. An alternative rational theory should be framed so that money may not originate as debt-money. Money must originate as debt-free. However, I am avoiding here to suggest how money can originate debt-free because this is outside the scope of this paper. I wish to write a separate paper on this issue. Economists and policymakers should find or formulate a new theory by which it will be possible to make money debt-free so that the economy may never be overburdened with increasing debt-burden.

\section{What new is added to the existing knowledge relating to money, monetary and fiscal policies:}

The Modern Money Theory is gaining ground among the economics policymakers' circle. Therefore, it becomes incumbent on the part of a researcher to assess whether the MMT has contributed any new theory or policy that may help to achieve uninterrupted economic growth and to secure more efficient production and distribution systems. However, from the critical assessment of the MMT, above, it 
emerges that the MMT has miserably failed to suggest any alternative policy or theory to that effect. The MMT is not really is in search of the origin and characteristics of money. What it wants is to re-interpret the history of money according to their incorrect theory of origin, definition, and function of money. They try to reduce even commodity-money which is exchanged at par its intrinsic value to the position of a debt-instrument. The principal defect in the monetary system is that money enters the economy as a loan from the central bank. Without going to solve this defect, the MMT argues that by nature money must be nothing but debt. Besides, MMT created more confusion in understanding what money is and how the monetary and the fiscal policies are being pursued. They argue that government can spend without caring for increasing debt (deficit), bonds are not a liability of the government but assets of the buyers (holder) of bonds, the government does not need tax and bond-sale for its spending purposes, commercial banks can create money out of nothing and so on.

This paper categorically identifies the contradictions in the arguments and explanations of the MMT. The purpose of this paper is to make the readers familiar with the irrational and impractical propositions of the MMT. The MMT is neither a theory on "money", nor a "theory" and definitely not "modern". The MMT is nothing but a hoax and fantasy.

The issues that should be addressed to achieve full employment are not (as the MMT thinks) whether the state is the sole authority to create money or whether money is created out of nothing as debt. What is needed is to formulate such a theory of money that may help money to originate as debt-free. Only then money will be sufficiently available to achieve full employment without causing an unbearable burden of the loan (deficit budget) for the government or for the economy as a whole.

\section{Limitations of my paper:}

I have tried to assess almost all the assertions or theories that are specialties of the MMT brand. However, I may miss or overlook certain points that need to be assessed.

However, it is necessary to define money and to trace its origin, but I have not tried to do that exercise, because the aim of this paper is only to make an assessment of what the MMT is or stands for. In this paper, I have avoided suggesting what should be the rational definition of money and how money can be created so that the government does not have to take any loan and sufficient money may be available for achieving full employment or to achieve a sustainable economic growth without being hampered by occasional downturns or recessions. I wish to write a separate paper on this issue.

\section{References:}

Adak, Naba Kumar. Oct.2016a. Proper Definition of Money is Necessary to Eliminate Business Cycles and Achieve Sustainable Economic Growth, Proceedings of 6th Global Business and Finance Research Conference, Taiwan, http://www.worldbizins.org/img/1499922068.pdf

Adak, Naba Kumar. Oct. 2016b. A Critical Assessment of 'A Meme for Money' written by L. Randall Wray Proceedings of $6^{\text {th }}$ Global Business and Finance Research, Taiwan, www.worldbizins.org/img/1499921846.pdf 
Adak, Naba Kumar Dec. 2016a. Caste System in India: A Unique Wisdom to Resolve Problems like Barter, Distribution and Unemployment, Proceedings of World Business and Social Science Research Conference, Bangkok, 9-10 December 2016, ISBN: 978-1-925488-22, www.assbri.org

Adak, Naba Kumar. Dec. 2016b. Debt is not Money, Proceedings of 14th Asian Business Research Conference, Dhaka, https://wbiworldconpro.com/pages/paper/dhaka-conference-2016/4195

Adak, Naba Kumar. Dec. 2016c. I Owe You (IOU) is Not Money, Proceedings of 14th Asian Business Research Conference, Dhaka - https://wbiworldconpro.com/uploads/dhaka-conference2016/management/1500346176.pdf

Adak, Naba Kumar. April 2017a. The Central Bank fraudulently creates money out of nothing but pushes it into the economy as if the money is representing some commodity, Proceedings of Conference, Tokyo, https://gribaconfo.com/wp-content/uploads/2017/05/215-Naba.pdf

Adak, Naba Kumar. April 2017b. The "True Full Employment" Prescribed by the Modern Money Theory is neither "True" Nor "Full" and nor "Employment", Proceedings of Tokyo Conference, https://gribaconfo.com/wp-content/uploads/2017/05/216-Naba.pdf

Adak, Naba Kumar. Aug. 2017. Banks Cannot Either Multiply or Increase the Amount of Money or Create Deposits Without Backing of Matching Reserve; Only Central Bank Creates Money, Proceedings of the Conference held in Vienna, International Institute of Social and Economic Sciences https://econpapers.repec.org/paper/sekiacpro/5808261.htm

Bell, Stephanie. April 1998. The Hierarchy of Money, Working Paper No. 231, The Jerome Levy Economics Institute

Bell, Stephanie. July 1998. Can Taxes and Bonds Finance Government Spending? Reserve Accounting and Government Finance, Working Paper No. 244, Jerome Levy Economics Institute

Bell, Stephanie. Nov 1999. Functional Finance: What, Why, and How?, Working Paper No. 287, University of Missouri Kansas City.

Boyer-Xambeu, Marie-Thérèse, Ghislain Deleplace, and Lucien Gillard. 1994. Private Money and Public Currencies, New York: M.E. Sharpe.

Buhlar, Georg. 1886. The Laws of Manu (A Translation of Manusmriti), Clarendon Press, Oxford

Cook, R.M. 1958. Speculation on the origins of coinage, Historia, 7:257-62.

Coy, Peter, Katia Dmitrieva and Matthew Boesler. March 2019. Warren Buffett Hates It. AOC Is for It. A Beginner's Guide to Modern Monetary Theory -An overview of a once-fringe school of economic thought that's suddenly of the moment. -Adapted by Bloomberg Businessweek from Macroeconomics, published by Red Globe Press

Davidson, Paul. 1997. Can Money Be Neutral Even In The Long Run? Chartalism V.S. Monetarism, Unpublished paper 
Fiebiger, Brett. 2013. A constructive critique of the Levy Sectoral Financial Balance approach: resurrecting a "Robin Hood" role for the state's taxing-and-spending functions -real-world economics review, issue no. 64, 2 July 2013, pp. 69-80

Foley, Duncan. 1989. Money in Economic Activity. The New Palgrave: Money, edited by John Eatwell

Fullwiler, Scott. July 2009.The Sector Fi nancial Balances Model of Aggregate Demand-Revised

Fullwiler, Scott, Stephanie Kelton, L. Randall Wray. January 2012. Modern Money Theory: A Response to Critics, in Modern Monetary Theory: A Debate, Working Paper Series 279

Godley, Wynne. 1999. Seven Unsustainable Processes -Medium-Term Prospects and Policies for the United States and the World -Secial Report, Levy Economics Institute

Godley, Wynne. March 2003. The U.S. Economy -A Changing Srtategic Predicament

Godley, Wynne. Izurieta, A., and Zezza, G., Aug 2004. Prospects and Policies for the U.S. Economy: Why Net Exports Must Now Be the Motor for U.S. Growth, Strategic Analysis, Levy Economics Institute, Annandale-on-Hudson, NY

Godley, Wynne. Papadimitriou, Dimitri B., and Zezza, Gennaro. Dec 2008. 'Prospects for the United States and the World: A Crisis that Conventional Remedies Cannot Resolve', Strategic Analysis, Levy Economics Institute, Annandale-on-Hudson, NY

Godley, Wynne. April 2005. Imbalances looking for a Policy, Policy Note -2005/4, Levy Economics Institute

Godley, Wynne. June 2005. Some Unpleasant American Arithmetic, Levy Economics Institute, Policy Note 2005-5

Godley, Wynne, Dimitri B. Papadimitriou, Greg Hannsgen and Gennaro Zezza. Nov 2007. The US Economy: Is there a way out of the woods? Levy Economics Inmstitute

Goodhart, Charles. 1996. The Two Concepts of Money and The Future of Europe, Unpublished paper.

Hurford, Peter and Fadhel Kaboub. 2012. The Employer of Last Resort: A Policy to Ensure Full Employment and Greater Price Stability, Department of Economics, Denison University Summer School Project

Ingham, Goeffrey. 1996. Money is a Social Relation, Review of Social Economy, Vol. LIV, No. 4, pp. 507-529.

Innes, A. Mitchell. May 1913. 2004. What is Money? in Wray, Credit and State Theories of Money, Edward Elgar,

Innes, A. Mitchell. May 1914. The Credit Theory of Money, Transcript from: The Banking Law Journal, Vol. 31(1914), Dec./Jan., Pages 151-168

Keynes, J.M. 1930. A Treatise on Money, New York: Harcourt Brace 
Kiyotaki, N. and R. Wright. 1987. "Acceptability, Means of Payment and Media of Exchange." The New Palgrave: Money, edited by John Eatwell, Murray Milgate, and Peter Newman. New York and London: W.W. Norton, pp. 3-5.

Knapp, Georg Friedrich. 1924. The State Theory of Money. Clifton, NY: Augustus M. Kelley.

Kraay, C.M. 1964. Hoards, small change and the origin of coinage, Journal of Hellenic Studies, 84:76-91

Laidler, David. 1987. Fiat Money. The New Palgrave: Money, edited by John Eatwell, Murray Milgate, and Peter Newman. New York and London: W.W. Norton, pp. 20-21.

Lerner, Abba P. Feb.1943. Functional Finance and the Federal Debt, Social Research, Vol. 10, No. 1, February, pp. 38-52.

Lerner, Abba P. 1947. Money As A Creature Of The State. American Economic Review, Vol. 37, No. 2, pp. 312-317

Menger, Carl. 1892. On the Origin of Money, Economic Journal, Vol. 2 (1892), pp.239-55, translated by Caroline A. Foley

Lerner, Abba P. Feb.1943. Functional Finance and the Federal Debt, Social Research, Vol. 10, No. 1, February, pp. 38-52.

Lerner, Abba P. 1947. Money As A Creature Of The State. American Economic Review, Vol. 37, No. 2, pp. 312-317.

Lerner, Abba P. 1951. Economics of Employment, New York: McGraw-Hill.

Menger, Karl. 1892. On The Origin of Money, Economic Journal, Vol. 2, No. 6, pp. 239-255.

Minsky, Hyman P. 1986. Stabilizing an Unstable Economy, Yale University Press, London

Mitchell, William. April 2013. Full Employment abandoned the triumph of ideology over evidence, Centre of Full Employment and Equity, Working Paper No. 13-02

Mosler, Warren B. 1995. Soft Currency Economics

Murphy, Robert P. June 2020. A Review of Stephanie Kelton's The Deficit Myth, Mises Wire

Nersisyan,Yeva \& L. Randall Wray. 10 April 2020. Are We All MMTers Now? Not so Fast, One Pager 63

Nersisyan, Yeva and Wray. June 2010. Does Excessive Sovereign Debt Really Hurt Growth? A Critique of This Time IS Different, by Reinhart and Rogoff, Working Paper 603

Nersisyan, Yeva and Wray. June 2010. Deficit Hysteria Redux?

Samuelson, Paul. 1973. Economics. 9th ed. New York, NY: McGraw-Hill. P-274-6 
Tcherneva, Pavlin. and L. Randall Wray. May 2005 - Can Basic Income and Job Guarantees Deliver on Their Promises, Working Paper No.42

Tcherneva, Pavlina July 2005. The Nature, Origins, and Role of Money: Broad and Specific Propositions and Their Implications for Policy, Working Paper No. 46

Tcherneva, Pavlina R. April 2018. The Job Guarantee: Design, Jobs, and Implementation, Working Paper No. 902 , The Levy Economics Institute of Bard College

Tymoigne, Eric and L. Randall Wray. July 2005. Money: An Alternative Story, Working Paper No. 45

Tymoigne, Eric and L. Randall Wray. Nov 2013. Modern Money Theory 101: A Reply to Critics, Working Paper No. 778, The Levy Economics Institute of Bard College

Tymoigne Éric May 2017, On the Centrality of Redemption: Linking the State and Credit Theories of Money through a Financial Approach to Money, WP 890

Wiser, William Henricks [1936] The Hindu Jajmni System - A Socio-Economic System Interrelating Members of a Hindu Village Community in Services, Munshiram Manoharlal Publishers Pvt. Ltd., New Delhi

Wolf Martin. July 2012. The Balance Sheet Recession In The US. Quoted in "Martin Wolf On Wynne Godley's Sectoral Financial Balances Approach" posted by by V. Ramanan on 2012 July 19 in Financial Times

Wray, L. Randall. 1990. Money and Credit in Capitalist Economies: The Endogenous Money Approach. Aldershot: Edward Elgar.

Wray, L. Randall. Nov, 1997. Government as Employer of Last Resort: Full Employment without Inflation, The Jerome Levy Economics Institute, Working Paper No. 213

Wray, Randall L. June 1998. Zero Unemployment and Stable Prices, Journal of Economic Issues, Vol. XXXII, No. 2

Wray, Randall L. Sept. 1998. Modern Money, Working Paper No. 252, The Jerome Levy Economics Institute

Wray, L. Randall. 01 July 2000. The Neo-Chartalist Approach to Money -Workong Paper No. 10

Wray, Randall L. Dec. 2001. Understanding Modern Money, Workshop on Understanding Unemployment in Australia, Japan and the USA: a Cross Country Analysis, Center of Full Employment and Equity

Wray, Randall L. Aug. 2003. Currency Sovereignty and the Possibility of Full Employment, Working Paper No. 28, Center for Full Employment and Price Stability

Wray, Randall L. April 2004. The Credit Money and State Money Approaches, Working Paper No. 32 
Wray, L. Randall. May 2004. In Defense of Employer of Last Resort

Wray, L. Randall. Jan. 2005. Full Employment through Job Guarantee - A response to critics of Employer of last resort approach to Full Employment, Working Paper No. 39

Wray L. Randall. \& Éric Tymoigne. July 2005. Money:An Alternative Story, Working Paper No. 45

Wray, L. Randall. 2006. The Social and Economic Importance of Full Employment

Wray, L. Randall. Aug, 2007. The Employer of Last Resort Programme: Could it Work for Developing Countries? Economic and Labour Market Papers, International Labour Office, Geneva

Wray, Randall L. July 2008. Macroeconomic Stability, Affordability and Manageability of Employer of Last Resort Programmes, PROOF

Wray, L. Randall. 2009. Understanding Modern Money: How a sovereign currency works: A Quiz, This quiz is based on one used by William Mitchell in a joint presentation Wary gave in Newcastle, Australia in May 2009

Wray, Randall L. Oct. 2009. An Alternative View of Finance, Saving, Deficits, and Liquidity, Working Paper No. 580, The Levy Economics Institute of Bard College

Wray, Jan. 2010. Alternative Approaches to Money, published in 'Theoretical Inquiries in Law' Journal, Vol. 11, No. 1.

Wray, L. Randall. Jan 2012. Imbalances? What Imbalances? A Dissenting View, Levy Economics Institute of Bard College -Working Paper No. 704

Wray, L. Randall. May 2012. Introduction to an Alternative History of Money, Levy Economics Institute, Working Paper No. 717

Wray, L. Randall. Nov. 2012. A Meme for Money, Working Paper 736, Levy Economics Institute

Wray, L. Randall. 2013. A New Meme for Money, Financial Crisis and the Nature of Capitalist Money, Palgrave Macmillan, pp. 79-100

Wray, L. Randall. March 2014. From the State Theory of Money to Modern Money Theory: An Alternative to Economics Orthodoxy, Working Paper No. 792, Levy Economics Institute of Bard College.

Wray, L. Randall. March 2014. Central Bank Independence: Myth and Misunderstanding, Working Paper 791

Wray, L. Randall. 14 May 2014. Do we need taxes? The MMT perspective

Wray, Randall L. [15 May 2014] - What are Taxes For? The MMT Approach

Wray, L. Randall. 02 June 2014, Taxes and the Public Purpose 
Wray, L. Randall. 17 June 2014. Tax Bads, Not Goods

Wray, Randall L. June 2014. Modern Money Theory: The Basics, New Economic Perspectives

Wray, Randy. 28 June 2014. Modern Monetary Theory - The Basics

Wray, L. Randall. 2015. Introduction: The Basics of Modern Money Theory, in Modern Money Theory

Wray, Randall L. 2015. Modern Money Theory: A Primer on Macroeconomics for Sovereign Monetary System

Wray, Randy Dec 2015. Debt-Free Money and Banana Republics

Wray, Randall. Nov. 2016. Taxes are for Redemption Not Spending, World Economic Review

Wray, Randall L. [Jan 2018] - Functional Finance: A Comparison of the Evolution of the Positions of Hyman Minsky and Abba Lerner, Working Paper No. 900, Levy Economics Institute and Bard College

Wray, Randall L. 01 Oct.2018. Modern Money Theory: How I came to MMT and What I Include in MMT

Wray, L. Randall. Sept 2019. Fiscal Reform to Benefit State and Local Governments: The Modern Money Theory Approach -Levy Economics Institute of Bard College, Working Paper No. 936

Wray, L. Randall. 01 Oct 2019. Alternative paths to modern money theory -Modern monetary theory and its critics -real-world economics review, issue no. 89

Wray, L. Randall. 14 Oct 2019. MMT: Report from the Front (Part2), New Economic Perspectives

Wray, L. Randall. 20 November 2019. Congressional Testimony: Reexamining the Economic Costs of Debt, Hearing before the House Budget Committee, 210 Cannon House Office Building

Wray, L. Randall. July 2020. The "Knnsas City" Approach to Modern Money Theory, Working Paper No. 961 